Cochrane Database of Systematic Reviews

\title{
Corticosteroids for acute bacterial meningitis (Review)
}

Brouwer MC, McIntyre P, Prasad K, van de Beek D

Brouwer MC, McIntyre P, Prasad K, van de Beek D.

Corticosteroids for acute bacterial meningitis.

Cochrane Database of Systematic Reviews 2015, Issue 9. Art. No.: CD004405.

DOI: 10.1002/14651858.CD004405.pub5.

www.cochranelibrary.com 
TABLE OF CONTENTS

HEADER

ABSTRACT

PLAIN LANGUAGE SUMMARY

SUMMARY OF FINDINGS

BACKGROUND

OBJECTIVES

METHODS

RESULTS

Figure 1.

Figure 2.

Figure 3.

Figure 4.

Figure 5.

Figure 6.

DISCUSSION

AUTHORS' CONCLUSIONS

ACKNOWLEDGEMENTS

REFERENCES

CHARACTERISTICS OF STUDIES

DATA AND ANALYSES

Analysis 1.1. Comparison 1 All patients, Outcome 1 Mortality.

Analysis 1.2. Comparison 1 All patients, Outcome 2 Severe hearing loss.

Analysis 1.3. Comparison 1 All patients, Outcome 3 Any hearing loss.

Analysis 1.4. Comparison 1 All patients, Outcome 4 Short-term neurological sequelae.

Analysis 1.5. Comparison 1 All patients, Outcome 5 Long-term neurological sequelae.

Analysis 1.6. Comparison 1 All patients, Outcome 6 Adverse events.

Analysis 2.1. Comparison 2 Children, Outcome 1 Mortality.

Analysis 2.2. Comparison 2 Children, Outcome 2 Severe hearing loss.

Analysis 2.3. Comparison 2 Children, Outcome 3 Any hearing loss.

Analysis 3.1. Comparison 3 Adults, Outcome 1 Mortality.

Analysis 3.2. Comparison 3 Adults, Outcome 2 Any hearing loss.

Analysis 3.3. Comparison 3 Adults, Outcome 3 Short-term neurological sequelae.

Analysis 4.1. Comparison 4 Causative species, Outcome 1 Mortality.

Analysis 4.2. Comparison 4 Causative species, Outcome 2 Severe hearing loss in children - non-Haemophilus influenzae species.

Analysis 4.3. Comparison 4 Causative species, Outcome 3 Severe hearing loss in children - Haemophilus influenzae. ..............

Analysis 5.1. Comparison 5 Income of countries, Outcome 1 Mortality - all patients.

Analysis 5.2. Comparison 5 Income of countries, Outcome 2 Severe hearing loss - all patients.

Analysis 5.3. Comparison 5 Income of countries, Outcome 3 Any hearing loss.

Analysis 5.4. Comparison 5 Income of countries, Outcome 4 Short-term neurological sequelae - all patients.

Analysis 5.5. Comparison 5 Income of countries, Outcome 5 Mortality - children.

Analysis 5.6. Comparison 5 Income of countries, Outcome 6 Severe hearing loss - children.

Analysis 5.7. Comparison 5 Income of countries, Outcome 7 Short-term neurological sequelae - children.

Analysis 5.8. Comparison 5 Income of countries, Outcome 8 Severe hearing loss in children due to non-Haemophilus influenzae species.

Analysis 5.9. Comparison 5 Income of countries, Outcome 9 Mortality - adults.

Analysis 5.10. Comparison 5 Income of countries, Outcome 10 Any hearing loss adults.

Analysis 6.1. Comparison 6 Timing of steroids, Outcome 1 Mortality.

Analysis 6.2. Comparison 6 Timing of steroids, Outcome 2 Severe hearing loss.

Analysis 6.3. Comparison 6 Timing of steroids, Outcome 3 Any hearing loss. 
Analysis 7.1. Comparison 7 Study quality, Outcome 1 Mortality.

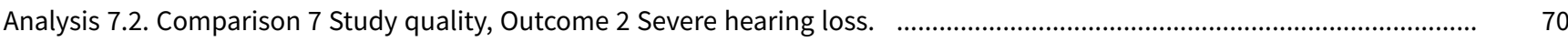

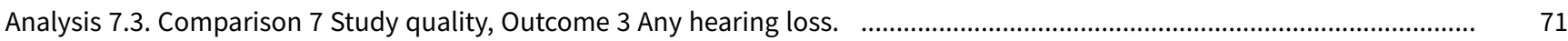

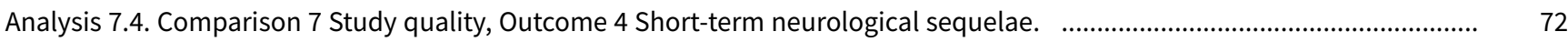

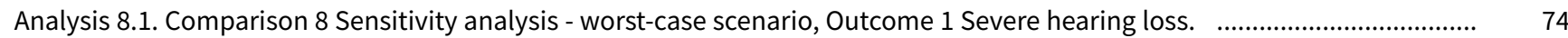

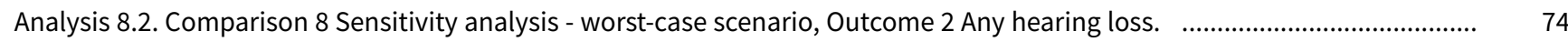

Analysis 8.3. Comparison 8 Sensitivity analysis - worst-case scenario, Outcome 3 Short-term neurological sequelae. .............. 75

Analysis 8.4. Comparison 8 Sensitivity analysis - worst-case scenario, Outcome 4 Long-term neurological sequelae. ............... 75 APPENDICES

FEEDBACK

WHAT'S NEW

HISTORY

CONTRIBUTIONS OF AUTHORS

DECLARATIONS OF INTEREST

SOURCES OF SUPPORT

DIFFERENCES BETWEEN PROTOCOL AND REVIEW

INDEX TERMS 
[Intervention Review]

\section{Corticosteroids for acute bacterial meningitis}

Matthijs C Brouwer ${ }^{1}$, Peter McIntyre ${ }^{2}$, Kameshwar Prasad ${ }^{3}$, Diederik van de Beek ${ }^{4}$

1Department of Neurology, Center for Infection and Immunity Amsterdam (CINIMA), Academic Medical Center University of Amsterdam, Amsterdam, Netherlands. ${ }^{2}$ National Centre for Immunisation Research and Surveillance of Vaccine Preventable Diseases, Children's Hospital at Westmead and University of Sydney, Sydney, Australia. ${ }^{3}$ Department of Neurology, All India Institute of Medical Sciences (AIIMS), New Delhi, India. ${ }^{4}$ Department of Neurology, Academic Medical Centre, University of Amsterdam, Amsterdam, Netherlands

Contact address: Diederik van de Beek, Department of Neurology, Academic Medical Centre, University of Amsterdam, P.O. Box 22660, Amsterdam, 1100 DE, Netherlands. D.vandeBeek@amc.uva.nl.

Editorial group: Cochrane Acute Respiratory Infections Group.

Publication status and date: Edited (no change to conclusions), comment added to review, published in Issue 11, 2018.

Citation: Brouwer MC, McIntyre P, Prasad K, van de Beek D. Corticosteroids for acute bacterial meningitis. Cochrane Database of Systematic Reviews 2015, Issue 9. Art. No.: CD004405. DOI: 10.1002/14651858.CD004405.pub5.

Copyright ( 2018 The Cochrane Collaboration. Published by John Wiley \& Sons, Ltd.

\section{A B S T R A C T}

\section{Background}

In experimental studies, the outcome of bacterial meningitis has been related to the severity of inflammation in the subarachnoid space. Corticosteroids reduce this inflammatory response.

\section{Objectives}

To examine the effect of adjuvant corticosteroid therapy versus placebo on mortality, hearing loss and neurological sequelae in people of all ages with acute bacterial meningitis.

\section{Search methods}

We searched CENTRAL (2015, Issue 1), MEDLINE (1966 to January week 4, 2015), Emabse (1974 to February 2015), Web of Science (2010 to February 2015), CINAHL (2010 to February 2015) and LILACS (2010 to February 2015).

\section{Selection criteria}

Randomised controlled trials (RCTs) of corticosteroids for acute bacterial meningitis.

\section{Data collection and analysis}

We scored RCTs for methodological quality. We collected outcomes and adverse effects. We performed subgroup analyses for children and adults, causative organisms, low-income versus high-income countries, time of steroid administration and study quality.

\section{Main results}

We included 25 studies involving 4121 participants ( 2511 children and 1517 adults; 93 mixed population). Four studies were of high quality with no risk of bias, 14 of medium quality and seven of low quality, indicating a moderate risk of bias for the total analysis. Nine studies were performed in low-income countries and 16 in high-income countries.

There was insufficient evidence that corticosteroids caused a reduction in mortality overall (17.8\% versus $19.9 \%$; risk ratio (RR) $0.90,95 \%$ confidence interval $(\mathrm{Cl}) 0.80$ to $1.01 ; \mathrm{P}=0.07$ ), or for adults ( $R R=.74,95 \% \mathrm{Cl} 0.53$ to $1.05 ; \mathrm{P}=0.09$ ). However they caused lower rates of severe hearing loss ( $R R 0.67,95 \% \mathrm{Cl} 0.51$ to 0.88 ), any hearing loss ( $\mathrm{RR} 0.74,95 \% \mathrm{Cl} 0.63$ to 0.87 ) and neurological sequelae (RR 0.83 , $95 \%$ $\mathrm{Cl} 0.69$ to 1.00$)$. 
Subgroup analyses for causative organisms showed that corticosteroids reduced mortality in Streptococcus pneumoniae (S pneumoniae) meningitis (RR $0.84,95 \% \mathrm{Cl} 0.72$ to 0.98 ), but not in Haemophilus influenzae ( $\mathrm{H}$ influenzae) orNeisseria meningitidis ( $N$ meningitidis) meningitis. Corticosteroids reduced severe hearing loss in children with $H$ influenzae meningitis (RR $0.34,95 \% \mathrm{Cl} 0.20$ to 0.59 ) but not in children with meningitis due to non-Haemophilus species.

In high-income countries, corticosteroids reduced severe hearing loss ( $\mathrm{RR} 0.51,95 \% \mathrm{Cl} 0.35$ to 0.73 ), any hearing loss ( $\mathrm{RR} 0.58,95 \% \mathrm{Cl} 0.45$ to 0.73 ) and short-term neurological sequelae (RR $0.64,95 \% \mathrm{Cl} 0.48$ to 0.85 ). There was no beneficial effect of corticosteroid therapy in low-income countries.

Subgroup analysis for study quality showed no effect of corticosteroids on severe hearing loss in high-quality studies.

Corticosteroid treatment was associated with an increase in recurrent fever (RR 1.27, 95\% $\mathrm{Cl} 1.09$ to 1.47 ), but not with other adverse events.

\section{Authors' conclusions}

Corticosteroids significantly reduced hearing loss and neurological sequelae, but did not reduce overall mortality. Data support the use of corticosteroids in patients with bacterial meningitis in high-income countries. We found no beneficial effect in low-income countries.

\section{PLAIN LANGUAGE SUMMARY}

\section{Corticosteroids for bacterial meningitis}

\section{Review question}

We reviewed the evidence about the effect of corticosteroids on mortality, hearing loss and/or neurological sequelae (such as hearing loss, neurologic deficits) in adults and children with acute bacterial meningitis.

\section{Background}

Acute bacterial meningitis is an infection of the meninges (the system of membranes that envelops the brain and spinal cord), which often causes hearing loss. Bacterial meningitis is fatal in $5 \%$ to $40 \%$ of children and $20 \%$ to $50 \%$ of adults despite treatment with adequate antibiotics. It is caused by bacteria that usually spread from an ear or respiratory infection and is treated with antibiotics.

Corticosteroids are drugs that can reduce the inflammation caused by infection. This inflammation has been shown to aggravate damage to the nervous system in experimental meningitis studies in animals. Research on the use of corticosteroids in addition to antibiotics has had conflicting results.

We wanted to discover whether use of corticosteroids was better of worse than placebo.

\section{Study characteristics}

The evidence is current to February 2015. We identified 25 trials, including 4121 participants with acute bacterial meningitis of which seven were performed in adults (over 16 years old), two included both children and adults and the other were performed in children. In 22 studies the corticosteroid used was dexamethasone, in three others hydrocortisone or prednisone were used. Nine studies were performed in lowincome countries and 16 in high-income countries.

\section{Key results}

This review found that the corticosteroid dexamethasone did not significantly reduce the death rate (17.8\% versus $19.9 \%)$. Patients treated with corticosteroids had significantly lower rates of severe hearing loss (6.0\% versus $9.3 \%)$, any hearing loss ( $13.8 \%$ versus $19.0 \%)$ and neurological sequelae (17.9\% versus $21.6 \%)$.

An analysis for different bacteria causing meningitis showed that patients with meningitis due to Streptococcus pneumoniae (S pneumoniae) treated with corticosteroids had a lower death rate $(29.9 \%$ versus $36.0 \%)$, while no effect on mortality was seen in patients with Haemophilus influenzae (H influenzae) and Neisseria meningitidis (N meningitidis) meningitis.

In high-income countries, corticosteroids reduced severe hearing loss, any hearing loss and short-term neurological sequelae. There was no beneficial effect of corticosteroid therapy in low-income countries.

Corticosteroids decreased the rate of hearing loss in children with meningitis due to $\mathrm{H}$ influenzae ( $4 \%$ versus $12 \%$ ), but not in children with meningitis due to other bacteria.

Dexamethasone increased the rate of recurrent fever (28\% versus $22 \%$ ) but was not associated with other adverse events.

\section{Quality of the evidence}

Out of 25 studies, four were of high quality, 14 of medium quality and seven of low quality, leading to a moderate overall quality of evidence. 


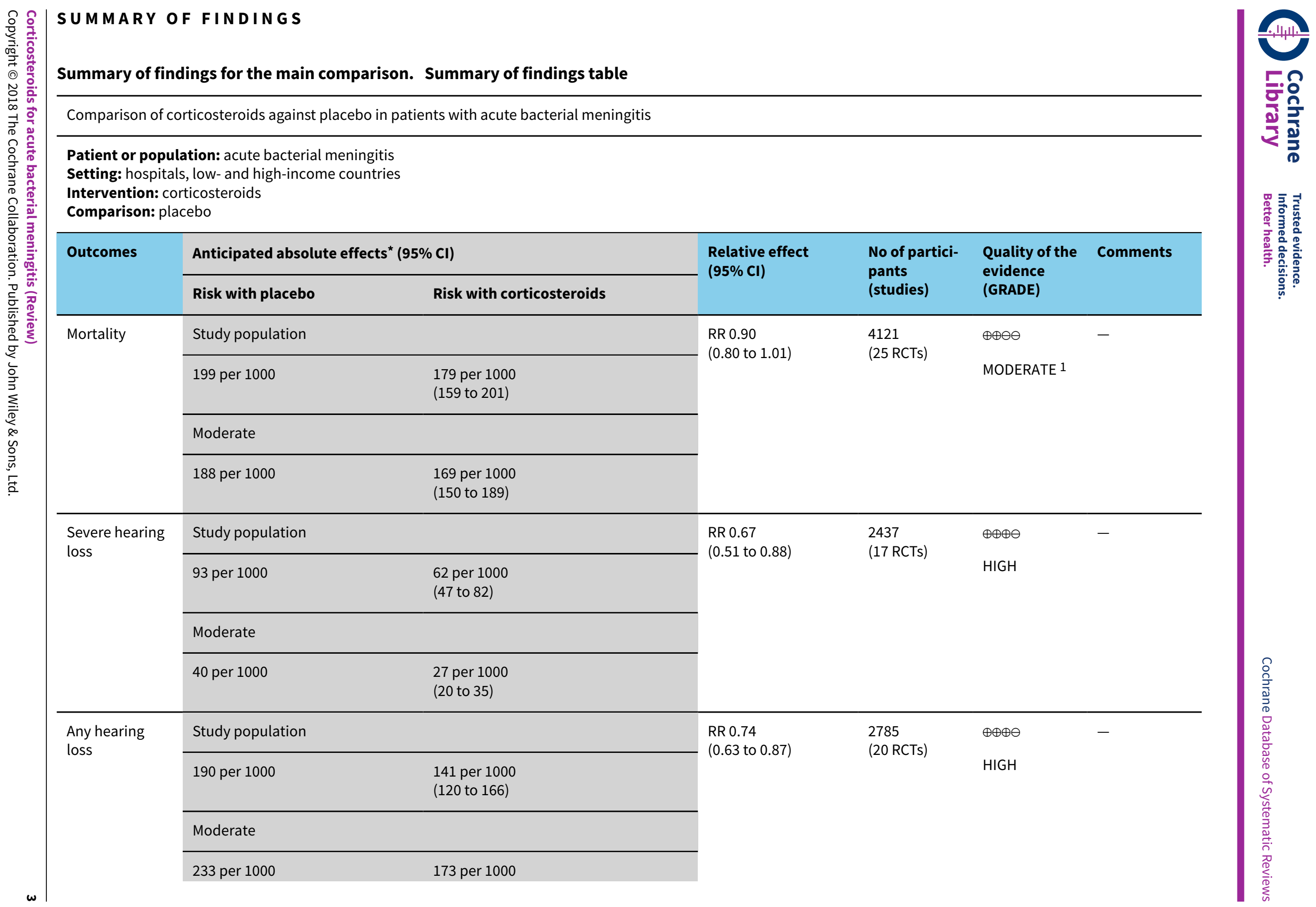




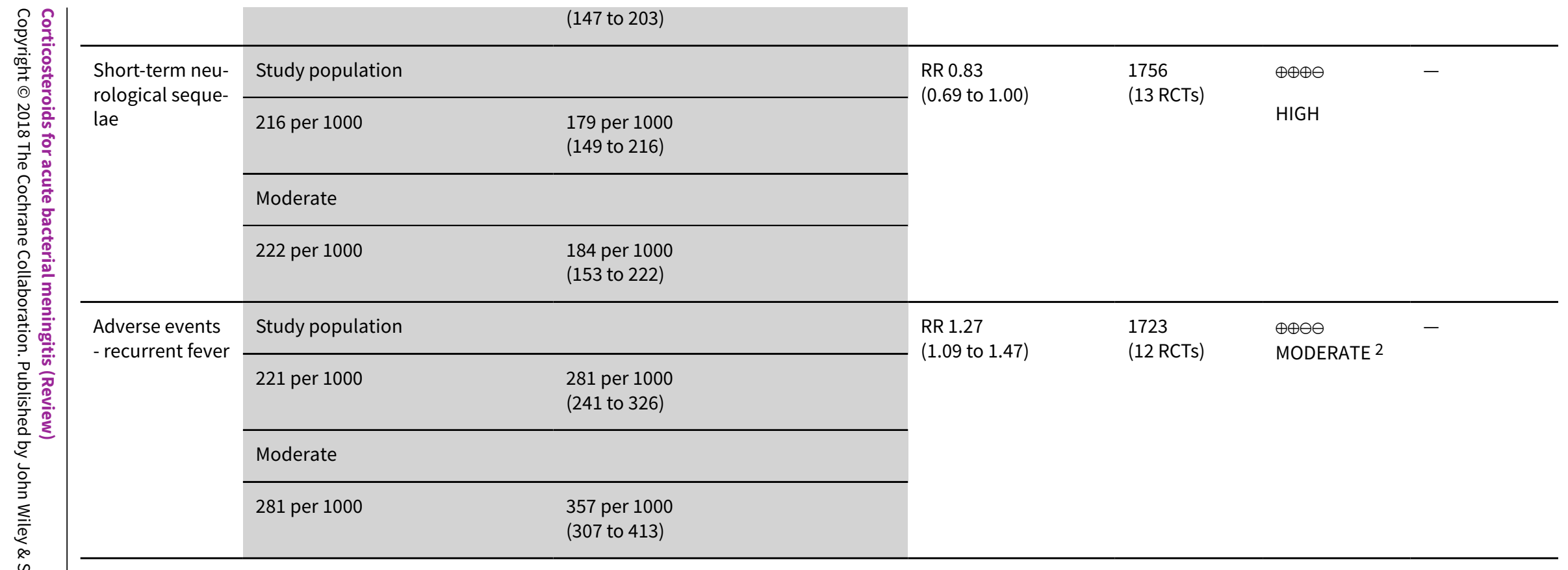

${ }^{*}$ The risk in the intervention group (and its $95 \%$ confidence interval) is based on the assumed risk in the comparison group and the relative effect of the intervention (and its $95 \% \mathrm{Cl}$ ).

CI: confidence interval; RR: risk ratio; OR: odds ratio

\section{GRADE Working Group grades of evidence}

High quality: We are very confident that the true effect lies close to that of the estimate of the effect

Moderate quality: We are moderately confident in the effect estimate: The true effect is likely to be close to the estimate of the effect, but there is a possibility that it is substantially different

Low quality: Our confidence in the effect estimate is limited: The true effect may be substantially different from the estimate of the effect

Very low quality: We have very little confidence in the effect estimate: The true effect is likely to be substantially different from the estimate of effect

1 Variable mortality between studies, consistent with differences across the world in meningitis prognosis.

2Different definitions used for recurrent fever makes this imprecise. 


\section{B A C K G R O U N D}

\section{Description of the condition}

Bacterial meningitis is a severe infection of the meninges (the membrane lining of the brain and spinal cord) that is associated with high mortality and morbidity rates despite optimal antibiotic therapy and advances in critical care (Baraff 1993; Bohr 1983; Brouwer 2010c; van de Beek 2002; van de Beek 2004b; van de Beek 2006b). Late sequelae such as cranial nerve impairment, especially hearing loss, occur in 5\% to 40\% of patients (Baraff 1993; Bohr 1983; Brouwer 2010b; Heckenberg 2012a; van de Beek 2002; van de Beek 2004b; van de Beek 2006b).

\section{Description of the intervention}

Intravenously or orally administered corticosteroids, such as prednisolone, hydrocortisone and dexamethasone, are given before, with or after antibiotic treatment for suspected or proven bacterial meningitis.

\section{How the intervention might work}

In experimental animal studies, the outcome of meningitis worsens with increasing severity of the inflammatory process in the subarachnoidal space (Scheld 1980; Tauber 1985). Treatment with corticosteroids was shown to result in a reduction of the inflammatory response in the cerebrospinal fluid (CSF), reversal of brain oedema and improved outcome (Scheld 1980; Tauber 1985). These pathophysiological insights prompted investigators to evaluate corticosteroids as an adjuvant therapy in acute bacterial meningitis.

\section{Why it is important to do this review}

In the 1960s two randomised controlled trials (RCTs) evaluated the effect of corticosteroids in patients with bacterial meningitis (Bennett 1963; DeLemos 1969). New randomised clinical trials were performed in the late 1980s and 1990s (Lebel 1988a; Lebel 1988b; Lebel 1989; Odio 1991), with conflicting results. Two meta-analyses of RCTs were published showing a reduction in bilateral hearing loss in dexamethasone-treated children with Haemophilus influenzae ( $H$ influenzae) meningitis (Geiman 1992; Havens 1989).

In the early 1990s the epidemiology of bacterial meningitis changed due to the introduction of the $H$ influenzae type $\mathrm{B}$ conjugate vaccine that resulted in near elimination of this bacterium as cause of meningitis in high-income countries (Peltola 2000). New trials were performed in children with bacterial meningitis, most commonly caused by Streptococcus pneumoniae (S pneumoniae). In 1997, a new meta-analysis was published showing adjunctive corticosteroid therapy to prevent hearing loss in patients with $H$ influenzae meningitis (McIntyre 1997). This meta-analysis also showed a beneficial trend of dexamethasone on neurological sequelae and hearing loss in patients with meningitis due to $S$ pneumoniae.

In the 2000s, five large randomised clinical trials have been performed. Two trials in children were performed in Malawi and South America and three trials in adults were performed in Europe, Vietnam and Malawi (de Gans 2002; Molyneux 2002; Nguyen 2007; Peltola 2007; Scarborough 2007). The European trial showed a beneficial effect in all patients, with the most apparent effect on mortality and unfavourable outcomes in pneumococcal meningitis (de Gans 2002). The Vietnamese trial showed a beneficial effect only in patients with proven bacterial meningitis (Nguyen 2007). The other trials did not show a beneficial effect. In 2010 an individual patient data meta-analysis was performed with patients from these five trials to determine in which subgroups of patients adjunctive dexamethasone was effective (van de Beek 2010). In this metaanalysis no benefit of adjunctive dexamethasone was found in any of the pre-specified subgroups. However, a post hoc analysis did show a reduction in any hearing loss in surviving patients treated with dexamethasone.

The results of many trials have been inconclusive and most studies have been relatively small. Trials have varied greatly in study population, study design, timing and dosage of corticosteroids. Furthermore, mortality was substantially higher in studies in lowincome countries, primarily related to access to care and comorbidities. This Cochrane systematic review and meta-analysis facilitates an interpretation of these varying results and might identify subgroups that benefit from adjunctive corticosteroid therapy. See Appendix 1 for a glossary of terms.

\section{O B JECTIVES}

To examine the effect of adjuvant corticosteroid therapy versus placebo on mortality, hearing loss and neurological sequelae in people of all ages with acute bacterial meningitis.

\section{METHOD S}

\section{Criteria for considering studies for this review}

\section{Types of studies}

Randomised controlled trials (RCTs).

\section{Types of participants}

Participants of any age and in any clinical condition.

\section{Types of interventions}

Participants with community-acquired bacterial meningitis treated with antibacterial agents and randomised to adjuvant corticosteroid therapy of any type.

\section{Types of outcome measures}

At least case-fatality rate or hearing loss had to be recorded for studies to be included.

\section{Primary outcomes}

1. Mortality

2. Hearing loss

3. Neurological sequelae

Hearing loss was defined as severe when there was bilateral hearing loss greater than $60 \mathrm{~dB}$ or requiring bilateral hearing aids. We analysed any hearing loss and severe hearing loss separately. Neurological sequelae were defined as focal neurological deficits other than hearing loss, epilepsy (not present before meningitis onset), severe ataxia and severe memory or concentration disturbance. We did not count children with isolated speech or language disturbances as having non-hearing deficits if these problems were associated with severe hearing loss. We analysed both short- and long-term neurological sequelae, other than 
hearing loss. Short-term neurological sequelae were defined as sequelae assessed between discharge and six weeks after hospital discharge. Long-term neurological sequelae were defined as sequelae assessed between six weeks and 12 months after discharge. Whenever possible, we extracted data for both these outcomes.

\section{Secondary outcomes}

\section{Adverse events}

Adverse events were defined as clinically evident gastrointestinal tract bleeding, reactive arthritis, pericarditis, herpes zoster or herpes simplex virus infection, fungal infection, recurrent fever (defined as a temperature of $38^{\circ} \mathrm{C}$ or above occurring after at least one afebrile day during the course of hospitalisation) and persistent fever (defined as fever continuing longer than five consecutive days after initiation of appropriate antibiotic therapy).

\section{Search methods for identification of studies}

\section{Electronic searches}

For this 2015 update we searched the Cochrane Central Register of Controlled Trials (CENTRAL 2015, Issue 1), which includes the Cochrane Acute Respiratory Infections Group Specialised Register, MEDLINE (January 2013 to January Week 4, 2015), Embase (January 2013 to February 2015), Web of Science (January 2013 to February 2015), CINAHL (January 2013 to February 2015) and LILACS (January 2013 to February 2015). Details of earlier searches are in Appendix 2.

We used the search strategy described in Appendix 3 to search CENTRAL and MEDLINE. We combined the MEDLINE search with the Cochrane Highly Sensitive Search Strategy for identifying randomised trials in MEDLINE: sensitivity- and precisionmaximising version (2008 revision); Ovid format (Lefebvre 2011). We adapted the search strategy to search Embase (Appendix 4), Web of Science (Appendix 5), CINAHL (Appendix 6) and LILACS (Appendix 7). We did not apply any language or publication restrictions.

\section{Searching other resources}

Besides the electronic search we identified relevant trials by searching references listed in published studies, handsearching congress abstracts, personal communication with researchers and experts in the field and from literature lists of pharmaceutical companies. We also searched the trials registries World Health Organization (WHO) International Clinical Trials Registry Platform (ICTRP) and ClinicalTrials.gov for completed and ongoing trials (June 2015).

\section{Data collection and analysis}

\section{Selection of studies}

Two review authors (MD, DvdB) independently screened the search results and retrieved the full articles of all potentially relevant trials. We scrutinised each trial report to ensure that multiple publications from the same trial were included only once. We resolved disagreements through discussion and listed the excluded studies and the reasons for their exclusion.

\section{Data extraction and management}

Two review authors (MB, DvdB) independently extracted data according to a pre-specified protocol. Data extracted included study design, inclusion criteria, patients' characteristics, country in which the study was performed, intervention characteristics and outcome measures. Scored intervention characteristics were corticosteroid type, daily corticosteroid dose, duration of steroid therapy and timing of corticosteroid therapy initiation (before/ with the first dose of antibiotic therapy, or after first dose of antibiotic therapy). We resolved disagreements through discussion and contacted the corresponding publication author in the case of unclear or missing data.

For dichotomous outcomes, we recorded the number of participants experiencing the event and the number randomised in each treatment group. To allow an available-case analysis, we recorded the numbers of participants analysed in each treatment group and used them in the analyses. However, we also recorded the number of participants randomised into the treatment arms and used the discrepancy between the figures to calculate the loss to follow-up. Also, these figures allowed a worst-case scenario analysis to be carried out to investigate the effect of missing data.

\section{Assessment of risk of bias in included studies}

For each study we completed a 'Risk of bias' table, scoring for adequacy of sequence generation, allocation concealment, blinding, if incomplete data were addressed, selective reporting and other sources of bias (Higgins 2011). We excluded studies without adequate sequence generation from the meta-analyses.

\section{Measures of treatment effect}

All outcome measures were dichotomous. We used risk ratios (RR) with $95 \%$ confidence intervals $(\mathrm{Cl})$ as measures of treatment effect.

\section{Unit of analysis issues}

For studies using multiple treatment groups, we included only groups receiving corticosteroids or placebo in the meta-analysis.

\section{Dealing with missing data}

We contacted the corresponding publication author in the case of unclear or missing data. If details were not provided, results used in the analysis were as provided in the publication.

We scored missing data in the outcome measures severe hearing loss and neurological sequelae for each study if reported. We assessed whether missing data were equally distributed between treatment and control groups using the $\mathrm{Chi}^{2}$ test. These tests were two-tailed and we considered a $\mathrm{P}$ value of $<0.05$ significant.

\section{Assessment of heterogeneity}

We assessed heterogeneity in all analysis with the 12 statistic with a value of $>=50 \%$ taken to indicate statistical heterogeneity.

\section{Assessment of reporting biases}

We conducted visual inspection of the funnel plot of the studies for any obvious asymmetry that could indicate publication bias. 


\section{Data synthesis}

We analysed the data using Review Manager 5.3 (RevMan 2014). We performed meta-analyses using the Mantel-Haenszel method with a fixed-effect model when heterogeneity was absent. When significant heterogeneity was established we used a randomeffects model.

\section{Subgroup analysis and investigation of heterogeneity}

We performed subgroup analyses for children and adults, causative organisms, low-income versus high-income countries, time of administration of steroids and quality of studies. Two age groups were defined: patients younger than 16 years and those aged 16 years and older. Three categories of causative organisms were defined: $H$ influenzae,Neisseria meningitidis ( $N$ meningitidis) and $S$ pneumoniae. We analysed studies in two subsets divided into lowincome and high-income countries. Low-income countries had a United Nations Human Development Index of less than 0.7 and high-income countries had an index of 0.7 or higher (UNHDI 2009). Studies were divided into three categories of methodological quality: high, medium and low according to the score in the 'Risk of bias' table. If all questions in the 'Risk of bias' table were answered positively we categorised the study as high quality, three through five as medium quality and less than three questions answered positively as low quality.

In the subgroup analysis we used the inverse variance method with a fixed-effect model to detect significant heterogeneity between subgroups, using a $\mathrm{P}$ value of $<0.05$ and $\mathrm{I}^{2}$ statistic $=>50 \%$.

\section{Sensitivity analysis}

For trials with missing data, we conducted two analyses: an available-case analysis and a worst-case scenario analysis. We considered all participants who had dropped out of the corticosteroid group to have an unfavourable outcome whereas we considered those who had dropped out of the control group to have a favourable outcome. We conducted a sensitivity analysis by imputing the missing data in this way to determine whether the overall results were sensitive to this assumption.

We performed additional random-effects model analyses for all studies without significant heterogeneity determined by the 12 statistic ( ${ }^{2}$ statistic $\left.<50 \%\right)$ to see if results were valid with this method as well.

Finally, we performed the analyses for the primary outcome measures without studies with unclear or unknown sequence generation.

\section{RES U L T S}

\section{Description of studies}

\section{Results of the search}

Since the first publication of this review we have retrieved a total of 4421 records. After removing duplicates we identified 3559 records in the electronic databases.

In the previous publications of this review, Brouwer 2013, we identified 40 potentially eligible trials, of which two were described in one paper (Lebel 1988a; Lebel 1988b). Two papers presented data from one study (Sankar 2007; Singhi 2008). In this 2015 search we did not identify any new trials for inclusion.

\section{Included studies}

A total of 25 studies were eligible for inclusion in the meta-analysis (Characteristics of included studies). These studies included 4121 patients (2064 dexamethasone, 2057 placebo). Participants over 16 years were included in seven studies (1517 patients: 756 dexamethasone, 761 placebo) (Bhaumik 1998; de Gans 2002; Girgis 1989; Nguyen 2007; Scarborough 2007; Thomas 1999). In two studies, participants older than 12 years were considered adults (Bhaumik 1998; Girgis 1989). The study intervention consisted of dexamethasone in 22 out of 25 studies; dosages ranged from 0.4 to $1.5 \mathrm{mg} / \mathrm{kg} / \mathrm{d}$ and duration ranged from two to four days. In the other studies hydrocortisone, prednisolone or a combination of both were given and duration ranged from three to 14 days (Bademosi 1979; Bennett 1963; DeLemos 1969).

Study medication was administered before or with the first dose of antibiotics in 13 studies, and after the first dose in eight studies. In four studies the time of administration was not stated.

A sample size calculation was given in eight studies (de Gans 2002; Mathur 2013; Molyneux 2002; Nguyen 2007; Peltola 2007; Qazi 1996; Scarborough 2007; Thomas 1999).

Mortality rates ranged from $0 \%$ to $54 \%$. In one study participants who died during the first 18 hours of admission were excluded (Belsey 1969); nevertheless, we included these participants in the meta-analysis. Hearing was assessed by audiometry in seven studies in children and four studies in adults; other studies used brainstem evoked potentials (10) or age-specific behavioural measures (eight). Four studies assessed both short-term and longterm neurological sequelae (Lebel 1988a; Lebel 1988b; Lebel 1989; Wald 1995). Definitions of adverse events were heterogeneous and we recalculated the number of events for each study.

Ethical review by hospital committees was described in 18 (72\%) studies. Eighteen (72\%) studies described informed consent procedures. There were no disagreements on inclusion or exclusion of studies between the review authors extracting study data. No study authors needed to be contacted to provide additional information for this updated version of the review.

Ten studies were funded in part by pharmaceutical companies, which were often only providing study medication. Five studies were funded by charities, four by government funding organisations, and funding was not reported for nine studies.

\section{Excluded studies}

We excluded 16 trials (Characteristics of excluded studies). Three studies did not randomise between treatment and control groups (Marguet 1993; Ozen 2006; Tolaj 2010). Nine trials did not adequately generate a randomisation sequence and in most of these alternate allocation schemes were used (Ayaz 2008; Baldy 1986; Daoud 1999; Gijwani 2002; Gupta 1996; Jensen 1969; Lepper 1959; Passos 1979; Shembesh 1997). One study compared two dexamethasone regimens (Syrogiannopoulos 1994), one was a duplicate study (Singhi 2008), and one study provided insufficient data (communications during scientific meetings only) (Farina 1995). 


\section{Risk of bias in included studies}

\section{Summary of general risk of bias}

Four of 25 studies were free of bias, whereas the other 21 had one or more biases. Attrition, reporting and potential selection bias were most common, occurring in eight, 18 and 12 studies (Figure 1). 
Figure 1. 'Risk of bias' summary: review authors' judgements about each methodological quality item for each included study.

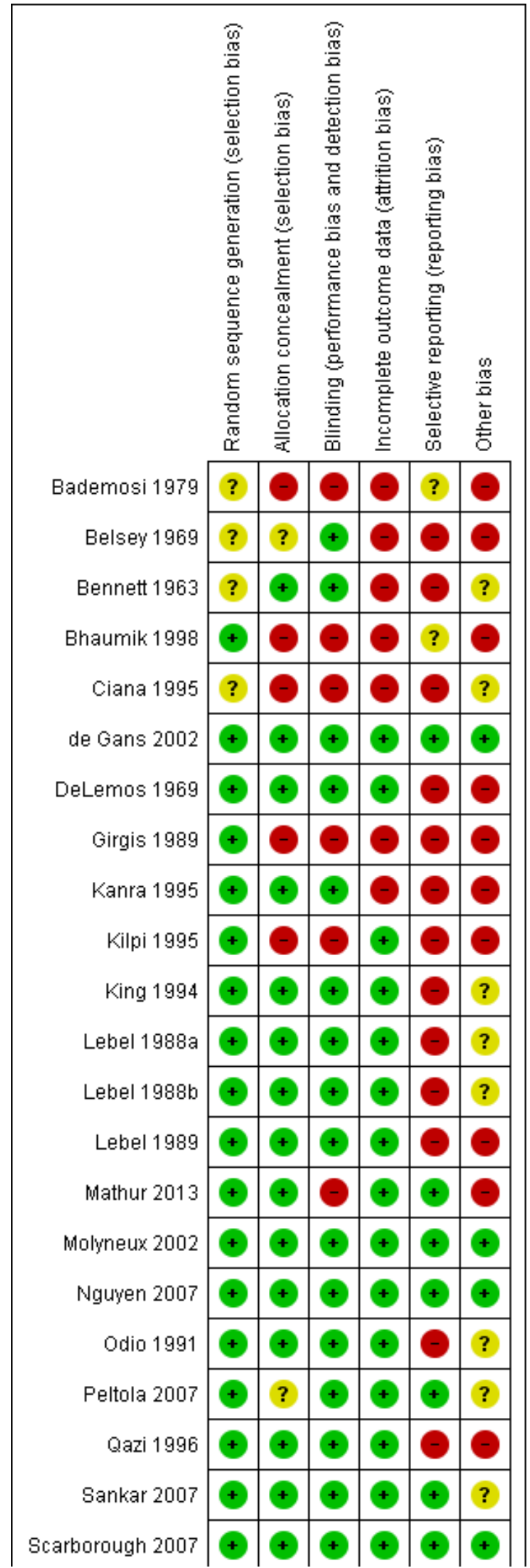


Figure 1. (Continued)

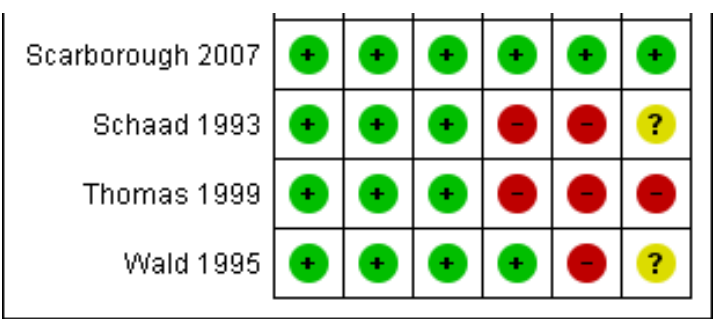

\section{Allocation}

The sequence generation for participant allocation was adequate in 20 studies. In five studies the method of sequence generation was unclear or not specified (Bademosi 1979; Belsey 1969; Bennett 1963; Ciana 1995; King 1994) (Figure 2; Figure 1). In five studies the treatment allocation was not concealed (Bademosi 1979; Bhaumik 1998; Ciana 1995; Girgis 1989; Kilpi 1995), and in one study treatment allocation concealment was unclear as participants were paired for placebo or dexamethasone
(Belsey 1969). A multicentre study performed in several South American countries compared two treatments in a $2 \times 2$ design, dexamethasone and glycerol with placebo, in four randomisation arms (glycerol-dexamethasone, glycerol-placebo, dexamethasoneplacebo, placebo-placebo). However, some centres did not include participants in the double placebo group, thereby disturbing the allocation concealment (Peltola 2007; van de Beek 2010). Data were extracted as derived from one study, comparing the dexamethasone-placebo versus placebo-placebo groups.

Figure 2. 'Risk of bias' graph: review authors' judgements about each methodological quality item presented as percentages across all included studies.

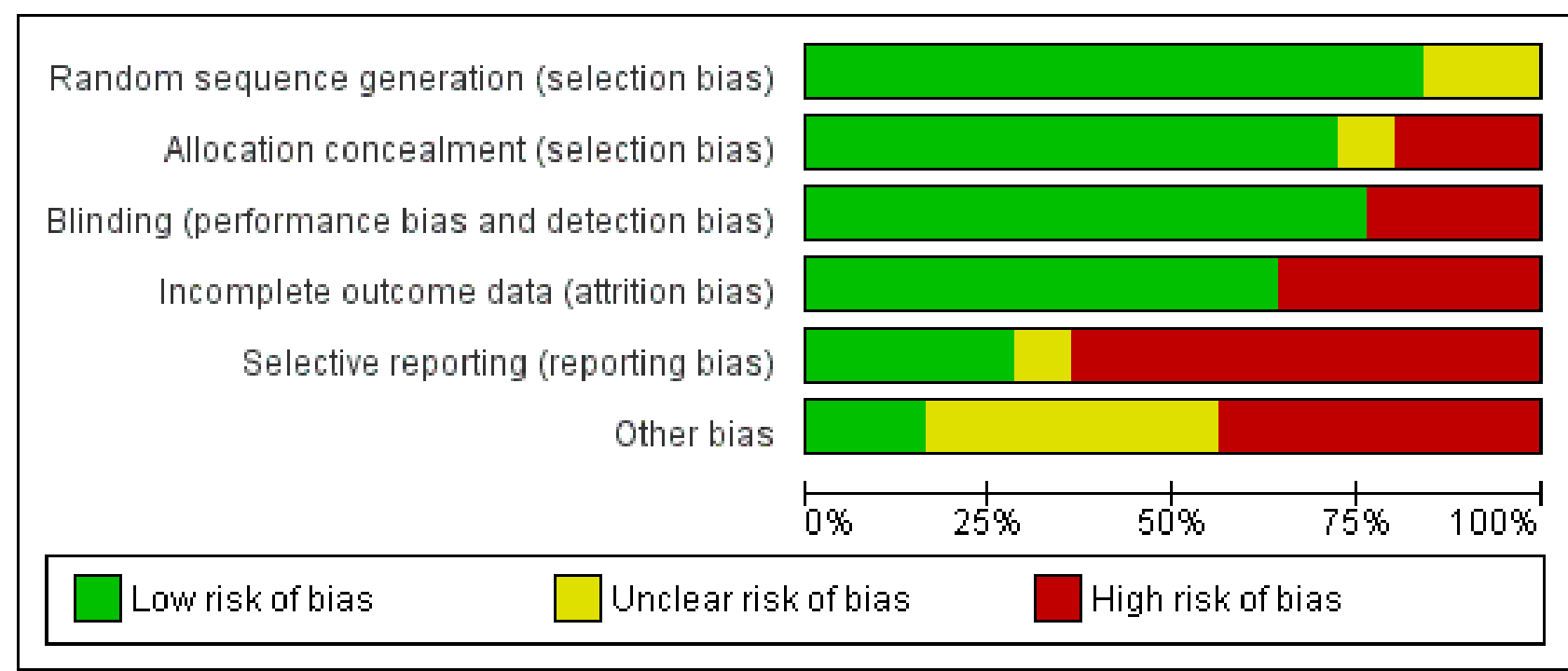

\section{Blinding}

Nineteen studies had a double-blind design and broke the treatment code after follow-up for the last participant was complete. Six studies did not use blinding (Bademosi 1979; Bhaumik 1998; Ciana 1995; Girgis 1989; Kilpi 1995; Mathur 2013).

\section{Incomplete outcome data}

Missing data were addressed in 16 studies and were not addressed in eight (Bademosi 1979; Belsey 1969; Bennett 1963; Bhaumik 1998; Girgis 1989; Kanra 1995; Schaad 1993; Thomas 1999). One study reported having complete data for all included participants (Mathur 2013). Out of 2694 survivors who were included in studies that analysed severe hearing loss, $216(8.0 \%)$ were not tested or had inconclusive test results. Data on any hearing loss were missing in 223 of $3029(7.4 \%)$ surviving participants included in studies that assessed hearing loss. Short-term neurological sequelae were assessed in 1695 of 1850 survivors included in studies that scored short-term sequelae; data on 155 (8.3\%) were missing. Data on long-term sequelae were missing in 157 of 1705 participants (9.2\%). The number of missing data was equally distributed between treatment and control group ( $P$ value for differences in missing data $>0.10$ for all analyses with missing data).

\section{Selective reporting}

An intention-to-treat (ITT) analysis was performed in six studies (de Gans 2002; Molyneux 2002; Nguyen 2007; Peltola 2007; Sankar 2007; Scarborough 2007), comprising 2147 out of 4041 participants (53\%). One study that reported no loss to follow-up or discontinuing treatment was analysed as ITT (Mathur 2013). In the other 18 studies only per-protocol data were available to be ascertained. The final analysis for mortality is equally based upon 
per-protocol figures (46\% of included participants) and ITT figures (56\%).

A study protocol with pre-specification of the analyses had not been published prior to publication of the complete study results for any of the included studies. None of the trials registered a study protocol in a trial registry.

Funnel plots of outcomes (mortality, any hearing loss, short-term neurological sequelae and long-term neurological sequelae and adverse events) did not show obvious asymmetry, except for severe hearing loss (Analysis 1.1; Analysis 1.2; Analysis 1.3; Analysis 1.4; Analysis 1.5; Analysis 1.6).

\section{Other potential sources of bias}

In 12 studies differences in baseline and clinical characteristics between treatment and control groups influenced comparability of groups (Bademosi 1979; Belsey 1969; Bhaumik 1998; DeLemos 1969; Kanra 1995; Kilpi 1995; Lebel 1989; Mathur 2013; Peltola 2007; Sankar 2007; Thomas 1999), indicating either insufficient sample size to equal out the random differences between randomisation arms or a selection bias. We found other indications of a selection bias in studies with high numbers of comatose participants or low numbers of culture-positive participants (Girgis 1989; Mathur 2013; Qazi 1996; Sankar 2007). Nine studies did not present sufficient participant characteristics to determine whether the participants in each randomisation arm were comparable.

\section{Effects of interventions}

See: Summary of findings for the main comparison Summary of findings table

\section{Primary outcomes}

\section{Mortality}

A lower overall number of deaths in the corticosteroid-treated group was observed compared to the placebo group (367 of 2064 $(17.8 \%)$ versus 408 out of 2057 (19.8\%), risk ratio (RR) 0.90, 95\% confidence interval $(\mathrm{Cl}) 0.80$ to $1.01, \mathrm{P}$ value $=0.07$ ), although the difference did not reach statistical significance (Bademosi 1979; Belsey 1969; Bennett 1963; Bhaumik 1998; Ciana 1995; de Gans 2002; DeLemos 1969; Girgis 1989; Kanra 1995; Kilpi 1995; King 1994; Lebel 1988a; Lebel 1988b; Lebel 1989; Mathur 2013; Molyneux 2002; Nguyen 2007; Odio 1991; Peltola 2007; Qazi 1996; Sankar 2007; Scarborough 2007; Schaad 1993; Thomas 1999; Wald 1995) (Analysis 1.1; Figure 3).

Figure 3. Forest plot of comparison: 1 All patients, outcome: 1.1 Mortality.

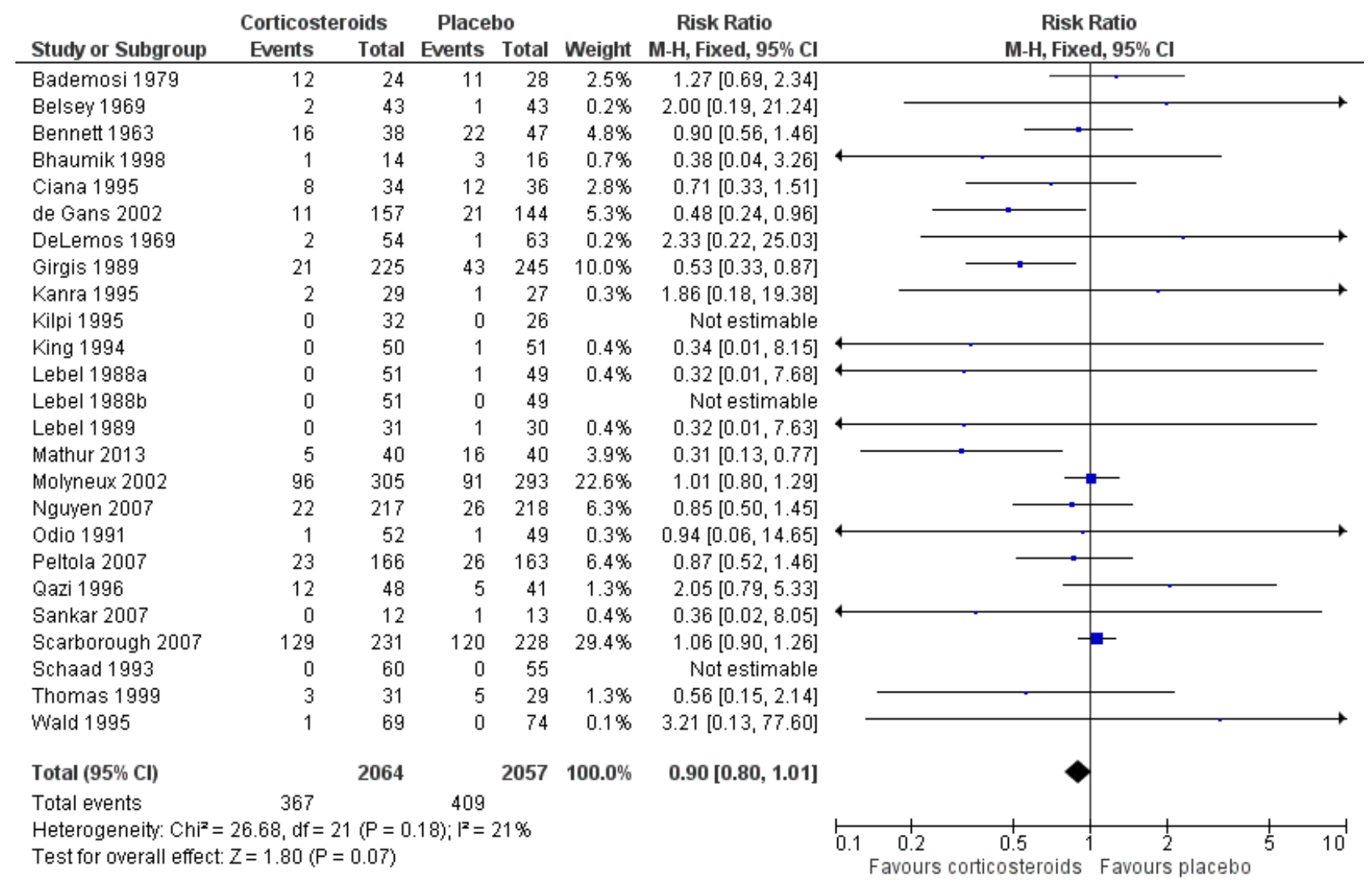

\section{Hearing loss}

The number of participants with hearing loss was significantly smaller in the corticosteroid-treated group than in the placebo group (any hearing loss: 197 of 1424 (14\%) versus 259 of 1361 (19\%), RR $0.74,95 \% \mathrm{Cl} 0.63$ to 0.87 ; severe hearing loss: 75 of $1234(6 \%)$ versus 112 of 1203 (9\%), RR 0.67, 95\% Cl 0.51 to 0.88 ) (Belsey 1969; Bhaumik 1998; de Gans 2002; Girgis 1989; Kanra 1995; Kilpi 1995; King 1994; Lebel 1988a; Lebel 1988b; Lebel 1989; Mathur 2013; Molyneux 2002; Nguyen 2007; Odio 1991; Peltola 2007; Qazi 1996; 
Sankar 2007; Scarborough 2007; Schaad 1993; Wald 1995) (Analysis

1.2; Analysis 1.3; Figure 4; Figure 5).

Figure 4. Forest plot of comparison: 1 All patients, outcome: 1.2 Severe hearing loss.

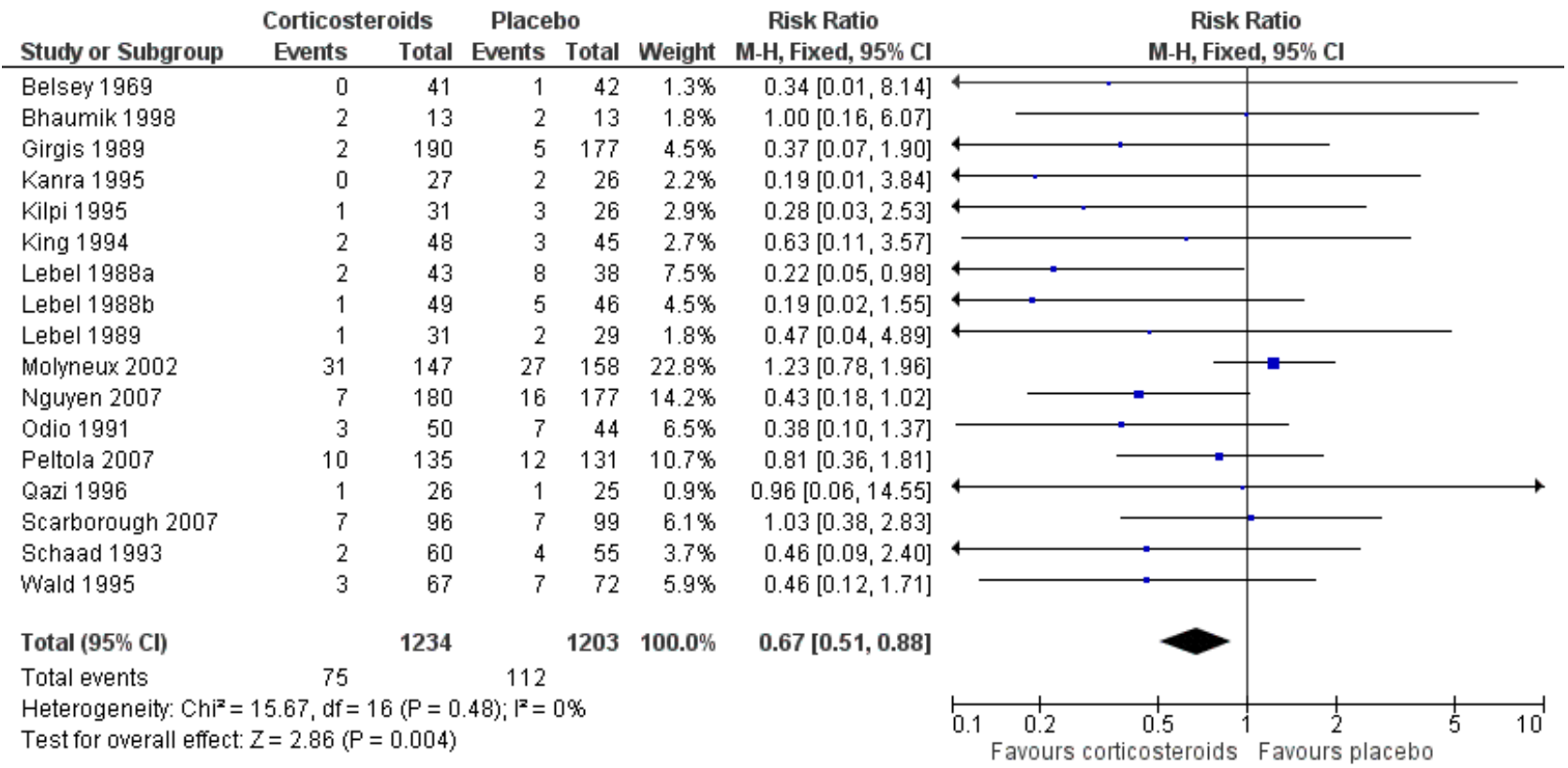

Figure 5. Forest plot of comparison: 1 All patients, outcome: 1.3 Any hearing loss.

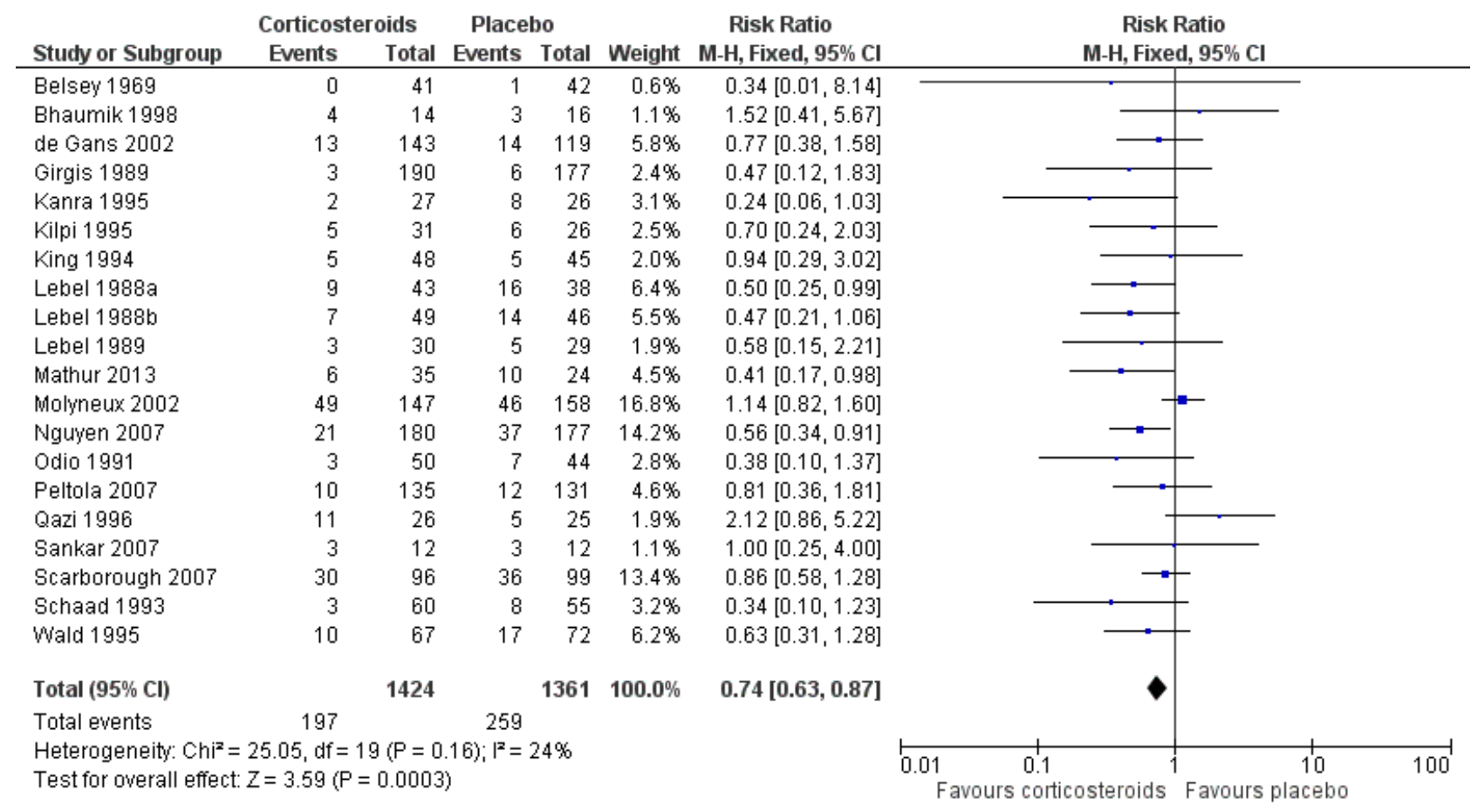

\section{Neurological sequelae}

Short-term neurologic sequelae (excluding hearing loss) were assessed in 13 studies including 1756 participants (Bhaumik 1998; Ciana 1995; de Gans 2002; Kanra 1995; Lebel 1988a; Lebel 1988b;
Lebel 1989; Molyneux 2002; Peltola 2007; Sankar 2007; Scarborough 2007; Thomas 1999; Wald 1995) (Analysis 1.4). Fewer sequelae were observed in the corticosteroid-treated group (161 of 900 (17.9\%) versus 185 of $856(21.6 \%)$, RR $0.83,95 \% \mathrm{Cl} 0.69$ to $1.00, \mathrm{P}$ value $=$ $0.05)$. Long-term neurological sequelae were assessed in 12 studies 
including 1652 participants (DeLemos 1969; Girgis 1989; Kanra 1995; Kilpi 1995; King 1994; Lebel 1988a; Lebel 1988b; Nguyen 2007; Odio 1991; Qazi 1996; Schaad 1993; Wald 1995) (Analysis 1.5). The occurrence of long-term sequelae was not significantly different between the corticosteroid-treated participants and the controls (125 of 836 (15.3\%) versus 136 of 816 (16.7\%), RR $0.90,95 \%$ Cl 0.74 to 1.10) (Analysis 1.5).

\section{Secondary outcome}

\section{Adverse events}

Adverse events were recorded in 20 studies: 16 evaluated gastrointestinal haemorrhage, 12 recurrent fever, six reactive arthritis, five herpes zoster, three persistent fever and one fungal infections (Belsey 1969; Bennett 1963; Bhaumik 1998; de Gans 2002; Kanra 1995; Kilpi 1995; King 1994; Lebel 1988a; Lebel 1988b; Lebel 1989; Mathur 2013; Nguyen 2007; Odio 1991; Peltola 2007; Qazi 1996; Sankar 2007; Scarborough 2007; Schaad 1993; Thomas 1999; Wald 1995) (Analysis 1.6; Figure 6). Participants treated with corticosteroids had an increase in recurrent fever (RR 1.27, 95\% $\mathrm{Cl} 1.09$ to 1.47). The rate of persistent fever was lower in the corticosteroid-treated patients ( $\mathrm{RR} 0.29,95 \% \mathrm{Cl} 0.12$ to 0.70 ). Other complications occurred in similar proportions of the treatment and control groups. 
Figure 6. Forest plot of comparison: 1 All patients, outcome: 1.6 Adverse events.

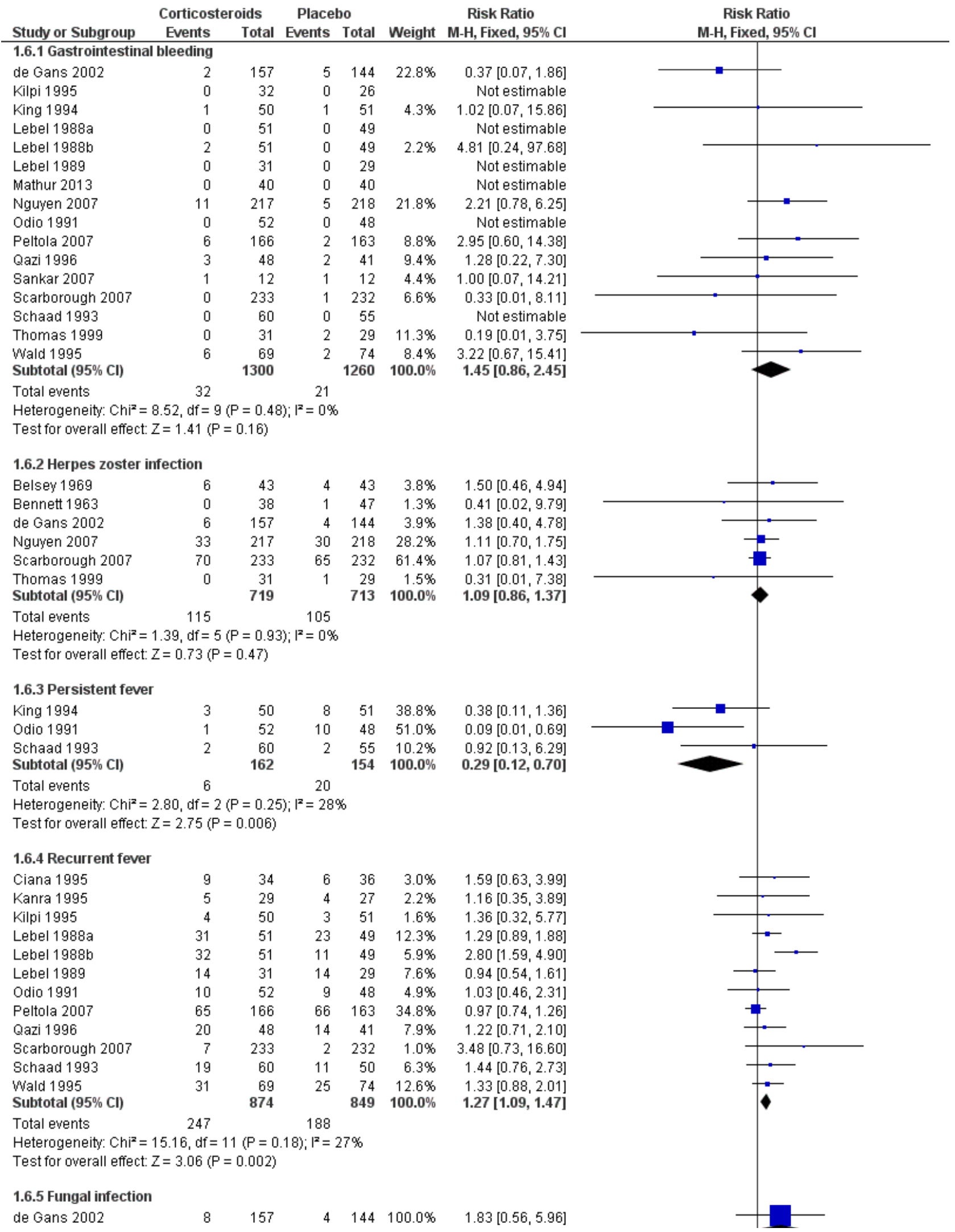


Figure 6. (Continued)

1.6.5 Fungal infection

\begin{tabular}{|c|c|c|}
\hline $\begin{array}{l}\text { de Gans } 2002 \\
\text { Subtotal }(95 \% \mathrm{Cl})\end{array}$ & 8 & $\begin{array}{l}157 \\
157\end{array}$ \\
\hline Total events & 8 & \\
\hline \multicolumn{3}{|c|}{ Heterogeneity: Not applicable } \\
\hline \multicolumn{3}{|c|}{ Test for overall effect: $Z=1.01(P=0.31)$} \\
\hline \multicolumn{3}{|l|}{ 1.6.6 Arthritis } \\
\hline Lebel 1988a & 1 & 51 \\
\hline Lebel 1988b & 0 & 51 \\
\hline Lebel 1989 & 1 & 31 \\
\hline Odio 1991 & 0 & 52 \\
\hline Schaad 1993 & 3 & 60 \\
\hline Wald 1995 & 2 & 69 \\
\hline Subtotal $(95 \% \mathrm{Cl})$ & & 314 \\
\hline
\end{tabular}

Total events $\quad 7 \quad 11$

Heterogeneity: $\mathrm{Chi}^{2}=5.94, \mathrm{df}=4(\mathrm{P}=0.20) ; \mathrm{I}^{2}=33 \%$

Test for overall effect: $Z=1.00(P=0.32)$

\section{$144-100.0 \%$ \\ $144100.0 \%$ \\ $1.83[0.56,5.96]$ \\ $1.83[0.56,5.96]$}

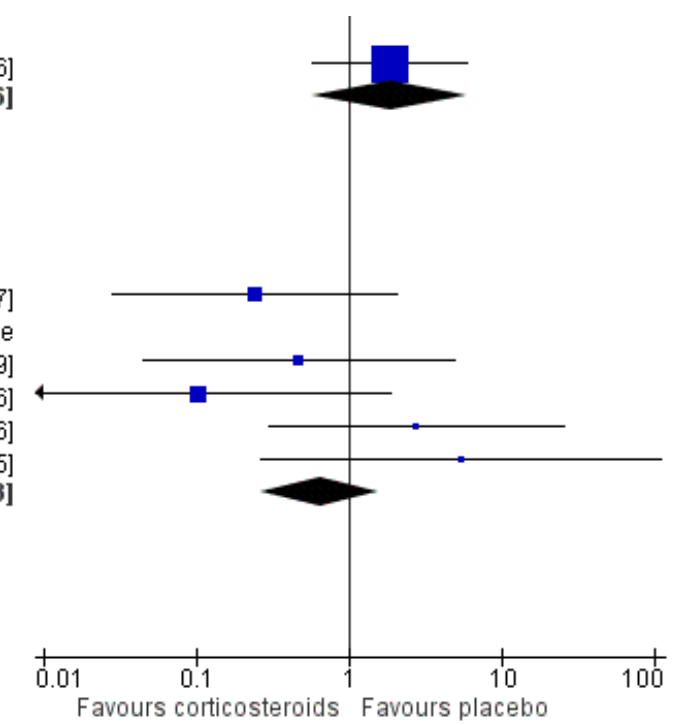

$33.0 \% \quad 0.24[0.03,2.07]$

Not estimable

$0.47[0.04,4.89]$

$0.10[0.01,1.86]$

$37.9 \%$

$8.4 \%$

$3.9 \%$

$100.0 \%$

$36[0.26,109.65]$

$0.64[0.27,1.53]$

\section{Subgroup analysis}

One hundred and sixty-seven children out of 1269 (13.1\%) in the corticosteroid-treated group died, compared to 182 of 1242 (14.7\%) in the placebo group (RR 0.89, 95\% Cl 0.74 to 1.07) (Belsey 1969; Ciana 1995; DeLemos 1969; Girgis 1989; Kanra 1995; Kilpi 1995; King 1994; Lebel 1988a; Lebel 1988b; Lebel 1989; Mathur 2013; Molyneux 2002; Peltola 2007; Qazi 1996; Sankar 2007; Schaad 1993; Mathur 2013) (Analysis 2.1).

Corticosteroids prevented hearing loss in children: any hearing loss was found in 146 of 1001 (14.6\%) corticosteroid-treated participants, compared to 196 of $960(20.4 \%)$ in the control group (RR $0.73,95 \% \mathrm{Cl} 0.61$ to 0.86 ); severe hearing loss was found in 57 of $772(7.3 \%)$ corticosteroid-treated participants, compared to 86 of $752(11.2 \%)$ in the control group (RR $0.67,95 \% \mathrm{Cl} 0.49$ to 0.91 ) (Analysis 2.3; Analysis 2.2).

For adults, study results on mortality were significantly heterogeneous $\left(1^{2}\right.$ statistic $\left.=54 \%\right)$. Using the random-effects model there was a non-significant reduction in mortality rate: 187 of $756(24.7 \%)$ died in the corticosteroid-treated group versus 215 of 761 (28.3\%; RR 0.74, 95\% Cl 0.53 to $1.05 ; \mathrm{P}=0.09$ ) (Bennett 1963; Bhaumik 1998; de Gans 2002; Girgis 1989; Nguyen 2007; Scarborough 2007; Thomas 1999) (Analysis 3.1). The rate of hearing loss in adults was lower in corticosteroid-treated participants as compared to controls ( 68 of 433 (15.7\%) versus 90 of 411 (21.9\%), RR $0.74,95 \% \mathrm{Cl} 0.56$ to 0.98 ; Analysis 3.2). There was a non-significant reduction in short-term neurologic sequelae in the corticosteroidtreated group (RR 0.72, 95\% Cl 0.51 to $1.01 ; \mathrm{P}=0.06$; Analysis 3.3).

Case-fatality rate varied according to causative micro-organism (Analysis 4.1). Out of 825 participants with $H$ influenzae meningitis, 87 died (10.5\%); compared to 371 of 1132 (32.8\%) participants with pneumococcal meningitis and 27 of 620 (4.3\%) participants with meningococcal meningitis. Corticosteroids protected against death in pneumococcal meningitis (RR $0.84,95 \% \mathrm{Cl} 0.72$ to 0.98) (Bademosi 1979; Bennett 1963; de Gans 2002; DeLemos 1969; Girgis 1989; Kanra 1995; Kilpi 1995; Lebel 1988a; Lebel 1988b; Molyneux 2002; Nguyen 2007; Odio 1991; Peltola 2007;
Scarborough 2007; Schaad 1993; Thomas 1999; Wald 1995). In meningococcal meningitis, corticosteroids were associated with a non-significant reduction in mortality (RR $0.71,95 \% \mathrm{Cl} 0.35$ to 1.46 ). For children with meningitis caused by $\mathrm{H}$ influenzae, hearing loss was significantly reduced by corticosteroids (RR $0.34,95 \% \mathrm{Cl} 0.20$ to 0.59; Analysis 4.3). For children with meningitis caused by bacteria other than Hinfluenzae, no significant beneficial effect was seen (RR $0.95,95 \% \mathrm{Cl} 0.65$ to 1.39 ; Analysis 4.2).

We analysed studies in two subsets divided into high-income (Belsey 1969; Bennett 1963; DeLemos 1969; de Gans 2002; Kanra 1995; Kilpi 1995; King 1994; Lebel 1988a; Lebel 1988b; Lebel 1989; Nguyen 2007; Odio 1991; Peltola 2007; Schaad 1993; Thomas 1999; Wald 1995) and low-income countries (Bademosi 1979; Bhaumik 1998; Ciana 1995; Girgis 1989; Mathur 2013; Molyneux 2002; Qazi 1996; Scarborough 2007; Sankar 2007).

The risk ratio for mortality in high-income countries was 0.81 (95\% $\mathrm{Cl} 0.63$ to $1.05, \mathrm{P}=0.10$ ) in corticosteroid-treated participants and 0.87 (95\% Cl 0.67 to 1.15 ; random-effects model; $\mathrm{I}^{2}$ statistic $55 \%$; Analysis 5.1) in low-income countries, with no heterogeneity between subgroups.

In high-income countries the rates of severe hearing loss (RR 0.51, $95 \% \mathrm{Cl} 0.35$ to 0.73 ; Analysis 5.2), any hearing loss (RR $0.58,95 \% \mathrm{Cl}$ 0.45 to 0.73 ; Analysis 5.3) and short-term neurologic sequelae (RR $0.64,95 \% \mathrm{Cl} 0.48$ to 0.85 ; Analysis 5.4) were lower in corticosteroidtreated participants and showed significant heterogeneity with rates in the low-income subgroup (severe hearing loss RR 0.99, $95 \% \mathrm{Cl} 0.72$ to $1.38, \mathrm{I}^{2}$ statistic for subgroups $86 \%$; any hearing loss RR $0.89,95 \% \mathrm{Cl} 0.76$ to $1.04, \mathrm{I}^{2}$ statistic $89 \%$; short-term neurological sequelae RR $1.03,95 \% \mathrm{Cl} 0.81$ to $1.31, \mathrm{I}^{2}$ statistic $84 \%)$. Subgroup analysis for children in high-income countries showed a decrease in risk of severe hearing loss and neurologic sequelae in the corticosteroid group (severe hearing loss, RR 0.52 , $95 \% \mathrm{Cl} 0.35$ to 0.78 ; short-term sequelae, RR $0.67,95 \% \mathrm{Cl} 0.46$ to 0.97 ), whereas no difference was seen in low-income countries (severe hearing loss, RR $1.00,95 \% \mathrm{Cl} 0.69$ to $1.47, \mathrm{I}^{2}$ statistic for subgroups $81 \%$; short-term sequelae, RR $1.08,95 \% \mathrm{Cl} 0.81$ to 1.43 , $\mathrm{I}^{2}$ statistic for subgroups 75\%) (Analysis 5.5; Analysis 5.6; Analysis 
5.7; Analysis 5.8). For adults in high-income countries, no significant heterogeneity between subgroups was found (Analysis 5.9; Analysis 5.10).

Subgroup analysis on timing of corticosteroids (before or with the first dose of antibiotics versus after the first dose of antibiotics) showed similar results for mortality (RR $0.8795 \% \mathrm{Cl} 0.69$ to 1.09 (I2 statistic 52\%, random-effects model); RR $0.83,95 \% \mathrm{Cl}$ 0.55 to 1.26 ) (Analysis 6.1; Analysis 6.2; Analysis 6.3; Analysis 6.4). For subgroup analyses of severe hearing loss and shortterm neurological sequelae, administration after the first dose of antibiotics had slightly more favourable point estimates than studies with early administration of corticosteroids, but there was no significant heterogeneity between subgroups.

We analysed studies in three categories of study quality according to the studies' 'Risk of bias' score (Figure 1). Four studies including 1793 participants were categorised as high quality (de Gans 2002; Molyneux 2002; Nguyen 2007; Scarborough 2007), 14 studies with 1477 participants as medium quality (DeLemos 1969; Kanra 1995; King 1994; Lebel 1988a; Lebel 1988b; Lebel 1989; Mathur 2013; Odio 1991; Peltola 2007; Qazi 1996; Sankar 2007; Sankar 2007; Schaad 1993; Thomas 1999; Wald 1995), and seven studies including 851 participants as low quality (Bademosi 1979; Belsey 1969; Bennett 1963; Bhaumik 1998; Ciana 1995; Girgis 1989; Kilpi 1995). No significant heterogeneity was found between subgroups of study quality for mortality, any hearing loss and short-term neurological sequelae (Analysis 7.1; Analysis 7.3; Analysis 7.4). Severe hearing loss was reduced in studies of medium quality (RR $0.47,95 \% 0.29$ to 0.75 ; Analysis 7.2 ), but not in studies of high and low quality, with significant heterogeneity between subgroups ( 12 statistic for subgroups $70 \%$ ).

\section{Sensitivity analysis}

In the worst-case scenario analyses where participants with missing data on severe hearing loss or any hearing loss in the corticosteroid groups were considered to have an unfavourable outcome, corticosteroids had no effect on severe or any hearing loss (Analysis 8.1; Analysis 8.2). In these analyses, studies were significantly heterogeneous and therefore we used the randomeffects model. One study provided $46 \%$ of missing values in the severe hearing loss analysis and $45 \%$ of missing values in the analysis on any hearing loss (Molyneux 2002). The worstcase scenario for short-term and long-term neurological sequelae showed no beneficial effect of corticosteroids (Analysis 8.3; Analysis 8.4). None of the worst-case scenarios showed evidence of harm with corticosteroid therapy.

Using the random-effects model in analyses with no significant heterogeneity, the beneficial effect effects of corticosteroids remained significant in Analysis 1.2, Analysis 1.3, Analysis 1.6, Analysis 2.2, Analysis 2.3, Analysis 3.2, Analysis 4.3, Analysis 5.2, Analysis 5.3, Analysis 5.4, Analysis 5.6, Analysis 5.7, Analysis 6.3 and Analysis 7.2. The decrease in short-term neurological sequelae did not remain significant with the random-effects model, but did show a trend towards benefit (RR $0.83,95 \% \mathrm{Cl} 0.69$ to 1.00 ; $P=0.05)$. The beneficial effect of corticosteroids on mortality in pneumococcal meningitis found with the fixed-effect model did not remain significant in the random-effects model (RR $0.81,95 \% \mathrm{Cl}$ 0.61 to $1.08 ; P=0.16$; Analysis 4.1).
The sensitivity analyses of studies with adequate sequence generation only showed that the decrease in short-term neurological sequelae did not remain significant (RR $0.83,95 \% \mathrm{Cl}$ 0.69 to 1.01 ). Results for other primary outcome measures did not differ from the initial analyses.

\section{DISCUSSION}

\section{Summary of main results}

This meta-analysis showed a beneficial effect of adjunctive corticosteroids in acute bacterial meningitis. Overall, corticosteroids significantly reduced the rate of hearing loss (risk ratio (RR) $0.74,95 \%$ confidence interval $(\mathrm{Cl}) 0.63$ to 0.87 ), severe hearing loss ( $\mathrm{RR} 0.67,95 \% \mathrm{Cl} 0.51$ to 0.88 ) and short-term neurological sequelae (RR $0.83,95 \% \mathrm{Cl} 0.69$ to 1.00 ). The use of adjunctive corticosteroids was associated with a non-significant decrease in mortality (RR $0.90,95 \% \mathrm{Cl} 0.80$ to 1.01). Use of adjunctive corticosteroids was not associated with a decrease in long-term neurological sequelae (RR $0.90,95 \% \mathrm{Cl} 0.74$ to 1.10 ). Recurrent fever occurred more often in corticosteroid-treated participants (RR $1.27,95 \% \mathrm{Cl} 1.09$ to 1.47 ), but other adverse events were found in similar proportions of the treatment and control group.

Subgroup analyses for age showed that in children with bacterial meningitis, corticosteroids prevented severe hearing loss (RR 0.67, $95 \% \mathrm{Cl} 0.49$ to 0.91 ) and any hearing loss (RR $0.73,95 \% \mathrm{Cl} 0.61$ to 0.86$)$. In adults, the rate of any hearing loss was lower in the corticosteroid-treated group (RR $0.74,95 \% \mathrm{Cl} 0.56$ to 0.98 ); there was a non-significant reduction in mortality in adults receiving corticosteroids (RR $0.74,95 \% \mathrm{Cl} 0.53$ to 1.05 , $\mathrm{P}$ value $=0.09$ ).

Subgroup analysis for causative organism showed that corticosteroids reduce severe hearing loss in children with meningitis due to $H$ influenzae (RR $0.34,95 \% \mathrm{Cl} 0.20$ to 0.59), while no effect of corticosteroids on hearing loss was observed in children with non-Haemophilus meningitis. Subgroup analysis on $S$ pneumoniae showed a favourable effect of corticosteroids on mortality (RR $0.84,95 \% \mathrm{Cl} 0.72$ to 0.98 ). A non-significant reduction in mortality was found in the $N$. meningitidis meningitis subgroup (RR $0.71,95 \% \mathrm{Cl} 0.35$ to 1.46 ). No effect on mortality was shown in $H$ influenzae meningitis.

Subgroup analysis for high-income and low-income countries showed no significant effect on mortality for corticosteroid-treated participants in high-income and low-income countries overall. Corticosteroids were protective against severe hearing loss (RR $0.51,95 \% \mathrm{Cl} 0.35$ to 0.73 ), any hearing loss (RR $0.58,95 \% \mathrm{Cl}$ 0.45 to 0.73 ) and short-term neurological sequelae (RR 0.64 , $95 \% \mathrm{Cl} 0.48$ to 0.85 ) in high-income countries, with significant heterogeneity between subgroups. For children in high-income countries, corticosteroids showed a protective effect against severe hearing loss (RR $0.52,95 \% \mathrm{Cl} 0.35$ to 0.78 ) and short-term neurological sequelae (RR $0.67,95 \% \mathrm{Cl} 0.46$ to 0.97 ). No effect was observed in low-income countries.

The sensitivity analyses showed that corticosteroids would have no effect on severe or any hearing loss and short- or longterm neurological sequelae if all missing data were imputed as unfavourable events in the corticosteroid-treated participants. Corticosteroids were not associated with harm in this worst-case scenario. Further sensitivity analyses showed that the effect of 
corticosteroids on overall short-term neurological sequelae and mortality in pneumococcal meningitis would not be significant if the random-effects model was used. The beneficial effect on shortterm neurological sequelae changed to a trend towards benefit if only studies with adequate sequence generation were included.

\section{Overall completeness and applicability of evidence}

\section{Overall completeness}

The available studies do not address four important issues - the minimum duration of corticosteroid therapy, type of corticosteroids, the maximum length of time after parenteral antibiotic therapy for commencement of corticosteroid therapy and long-term effect of corticosteroid therapy. In most studies, a four-day regimen of dexamethasone ( 0.4 or $0.6 \mathrm{mg} / \mathrm{kg} /$ day) divided into four daily doses was used. One randomised, prospective study involving 118 children with bacterial meningitis showed a two-day and four-day regimen of dexamethasone to be similarly effective (Syrogiannopoulos 1994). In this study physicians were not blinded to the treatment groups. Long-term neurological sequelae, or moderate hearing impairment (or both), were found in $1.8 \%$ and $3.8 \%$ of patients treated with dexamethasone for two and four days, respectively. It is unlikely that a randomised controlled trial (RCT) will be performed to answer the question of whether a two-day or four-day regimen should be used in bacterial meningitis; such a clinical trial would need a very large number of patients enrolled to detect significant differences between groups. Since most studies used a four-day regimen (without increase of side effects) we advise the use of the four-day corticosteroid therapy.

Three studies used hydrocortisone and/or prednisolone; all others used dexamethasone. Clinical efficacy depends on glucocorticoid pharmacokinetics and pharmacodynamics; of glucocorticoids, dexamethasone has superior penetration in the cerebrospinal fluid (CSF) and a longer half life (Balis 1987). Therefore, dexamethasone is considered to be the corticosteroid of choice in bacterial meningitis.

Subgroup analyses for timing of corticosteroids (before or with the first dose of antibiotics versus after the first dose of antibiotic) showed no differences in efficacy of corticosteroids. In previous reports, administration of corticosteroids before or with the first dose of parenteral antibiotics seemed to be more effective than administration after the first dose of antibiotics (King 1994; Mclntyre 1997). A RCT involving 301 adults with bacterial meningitis in European countries showed a beneficial effect of the corticosteroid dexamethasone on unfavourable outcome and mortality (de Gans 2002). In this European study, dexamethasone or placebo was administered before or with the first dose of antibiotic (de Gans 2002). The beneficial effect of dexamethasone on mortality was most apparent in patients with pneumococcal meningitis. In a post hoc analysis of this study, the beneficial effect of dexamethasone on mortality in patients with pneumococcal meningitis was attributable to a reduction in systemic complications (van de Beek 2004a). Although speculative and not supported by clinical data, one implication of this finding might be that the effect of dexamethasone is not restricted to the first hours after administration (van de Beek 2006b).

A meta-analysis of individual patient data (van de Beek 2010) was performed with five recent large RCTs on adjunctive dexamethasone therapy in bacterial meningitis (de Gans 2002;
Molyneux 2002; Nguyen 2007; Peltola 2007; Scarborough 2007). Data from 2029 patients from five trials were included and the aim of this analysis was to establish whether any subgroups of patients with acute bacterial meningitis might benefit from adjunctive dexamethasone. Extensive exploration of 15 prespecified subgroups did not show robust evidence that a particular subgroup would benefit; although there was a benefit in adults aged over 55 years (McIntyre 2010; van de Beek 2010). There were no differences in efficacy of adjunctive dexamethasone with regard to the timing of corticosteroids.

In experimental pneumococcal meningitis, CSF bacterial concentrations appeared to be more important than the timing of dexamethasone therapy in influencing the antibacterial-induced inflammatory response (Lutsar 2003). Hence, there is a time period beyond which corticosteroid loses its effectiveness after the first (parenteral) administration of an antibiotic agent but this time interval has not been clearly defined. On the basis of the available evidence, dexamethasone should be preferably started before or with the first dose of antibiotic therapy.

A long-term follow-up study on adjunctive dexamethasone treatment in tuberculous meningitis showed the initial beneficial effect of adjunctive dexamethasone was abolished because of delayed mortality within five years (Török 2011). To assess the long-term effects of adjunctive corticosteroid treatment in bacterial meningitis and determine whether a similar phenomenon could be identified, a long-term follow-up study was performed in participants included in the European Dexamethasone Study (de Gans 2002; Fritz 2012). The study included 228 of 246 evaluable participants surviving the initial trial period. After a median followup of 13 years, mortality in the dexamethasone group was $22 \%$ compared to $33 \%$ in the placebo group $(P=0.029)$ (Fritz 2012). The authors conclude that the beneficial effect of dexamethasone that is obtained in the acute phase of the disease remains for years. This provides another reason to administer adjunctive corticosteroids in adult bacterial meningitis patients in high-income countries.

However, long-term follow-up studies of patients included in other RCTs are needed to confirm the persistence of benefit from adjunctive dexamethasone.

\section{Applicability of evidence}

In children with acute bacterial meningitis, corticosteroids reduced hearing loss from $20.4 \%$ to $14.6 \%$ and severe hearing loss from $11.2 \%$ to $7.3 \%$. A large proportion of included children had meningitis due to $H$ influenzae type $B$, which has been virtually eliminated in high-income countries since routine vaccination of children against this bacterium started (McIntyre 2012; Peltola 2000; van de Beek 2006b). Nevertheless, subgroup analysis in children in high-income countries showed a protective effect of adjunctive corticosteroids on severe hearing loss overall and a favourable point estimate for severe hearing loss due to non-Haemophilus meningitis. The results of this review support the use of adjunctive corticosteroids in children in high-income countries with meningitis due to all micro-organisms based on the lack of evidence of adverse events (in general and microorganism specific) of dexamethasone in the corticosteroid-treated group. However, as conclusive evidence is lacking for this subgroup, administration of corticosteroids to children with meningitis due to bacteria other than $\mathrm{H}$ influenzae remains controversial. 
Only one study in this analysis involved children with neonatal meningitis and showed a beneficial effect of corticosteroids on outcomes (Mathur 2013). However, the study was relatively small and treatment groups were not well balanced with regards to patient age, culture positivity and causative micro-organisms. Additional RCTs evaluating corticosteroids in neonatal meningitis need to be performed before definitive conclusions can be drawn on the role of dexamethasone treatment in neonatal meningitis.

On the basis of the benefits of corticosteroid therapy in the adult population in high-income countries, dexamethasone should be commenced in adults with suspected or proven communityacquired bacterial meningitis in high-income countries (van de Beek 2006a). For adults in low-income countries, the use of corticosteroids is neither beneficial nor harmful.

The use of steroids was associated with fewer cases of persistent fever and more cases of recurrent fever, but not with serious adverse events. However, definitions of adverse events used in the studies were heterogeneous and most studies had no specified criteria in advance, so under-ascertainment is likely.

Concerns have been raised over the interference by corticosteroids in CSF eradication of meningeal pathogens by reducing the blood-brain barrier permeability and thereby the penetration of antibiotics in the subarachnoid space. Therapeutic failures have been described in adults treated with standard doses of vancomycin and adjunctive dexamethasone (Viladrich 1991). However, two studies showed with repeated lumbar punctures that, in both adults and children, treatment with dexamethasone did not reduce vancomycin levels in the CSF (Klugman 1995; Ricard 2007). Although these results are reassuring, patients with pneumococcal meningitis who are treated with vancomycin and dexamethasone should still be carefully observed throughout therapy (van de Beek 2006a).

In adults who survive acute bacterial meningitis, cognitive impairment occurs frequently (van de Beek 2002; van de Beek 2006a). As corticosteroids may potentiate ischaemic injury to neurons (Sapolsky 1985), it is important to know whether corticosteroids have beneficial effects on hearing loss and mortality but worsen cerebral cortical functioning (van de Beek 2006b). Neuropsychological outcome was evaluated in patients included in the European Dexamethasone Study who survived pneumococcal or meningococcal meningitis (Weisfelt 2006). In 87 out of 99 eligible patients, $46(53 \%)$ of whom were treated with dexamethasone and $41(47 \%)$ of whom received placebo, no significant differences in outcome were found between patients in the dexamethasone and placebo groups (medium time between meningitis and testing was eight years). In another study on long-term neuropsychological outcomes and dexamethasone in children, children who contracted pneumococcal meningitis and were treated with corticosteroids showed better academic achievements compared with children with pneumococcal meningitis who were not treated with adjunctive corticosteroids (Ozen 2006).

\section{Quality of the evidence}

Of the 25 randomised clinical trials included in the meta-analysis four were of high quality, 14 of medium quality and seven of low quality. Although the number of high-quality studies was low, the number of participants in these studies accounted for $45 \%$ of participants included in the meta-analysis. Studies were mostly categorised as medium or low quality due to a lack of addressing missing data or because no intention-to-treat analysis was performed. For the analysis on severe hearing loss, significant heterogeneity between trials of high, medium and low quality was found. As studies of high quality showed no effect the results of this meta-analysis should interpreted with caution.

The sensitivity analysis showed that in a worst-case scenario dexamethasone would have no beneficial or harmful effect on hearing loss or neurological sequelae. However, this analysis was heavily influenced by a single study accounting for $46 \%$ of missing values. When this study was left out a trend towards benefit of dexamethasone on any hearing loss was found (Molyneux 2002). Further sensitivity analyses showed that the effect of corticosteroids on overall short-term neurological sequelae and mortality in pneumococcal meningitis would not be significant if the random-effects model was used.

\section{Potential biases in the review process}

Several biases may have diminished the reliability of our results. The first confounding factor is selection bias. Several studies on childhood meningitis had exceptionally low mortality rates; nine studies had mortality rates of $3 \%$ or less. Mortality rates of childhood bacterial meningitis in previous reported studies ranged from $8 \%$ to $20 \%$ (Baraff 1993; Bohr 1983). Inclusion of studies in the meta-analysis with less severe illness, as reflected in the very low case-fatality rates, will probably underestimate the protective effect of corticosteroids (Glasziou 1995). Five studies had very high mortality rates (over $25 \%$ ). For patients admitted in a late state of disease, adjuvant corticosteroids are less protective and might even be harmful (Prasad 1995). Inclusion of such patients might again lead to an underestimation of the treatment effect.

A second bias is introduced when participants are withdrawn (Prasad 1995; Qazi 1996). The analysis was based upon per-protocol figures, as intention-to-treat (ITT) figures were only available for six studies (24\%). A total of 211 participants were withdrawn after the randomisation process, often for unknown reasons. Reasons for withdrawal include ineligibility according to the trial criteria or inability to complete the treatment protocol (Prasad 1995). Withdrawals on the grounds on ineligibility may have been influenced by knowledge of outcome; if so, this would advantage the corticosteroid regimen. Excluding participants because of an inability to complete the course of corticosteroids due to side effects (for example, upper gastrointestinal bleeding) clearly introduces bias in favour of the study medication, whereas withdrawals due to loss to follow-up might favour the placebo group. In the Egyptian study, which was not placebo-controlled and not double-blinded, only three pathogens were cultured from the cerebral spinal fluid of enrolled participants, suggesting withdrawal of participants with other bacteria culture from CSF and those with negative CSF cultures (Girgis 1989).

A third bias is introduced by competing risks. The comparisons of hearing loss and neurologic sequelae (other than hearing loss) were made excluding all participants who died. Since mortality is possibly a treatment-related outcome, the treatment groups that exclude fatality cases may not be comparable. Competing risks in this analysis will lead to an underestimation of the treatment effect of corticosteroids. 
Finally, the included studies were heterogeneous with respect to the study protocols. The first study was published in 1963 (Bennett 1963), the last in 2012 (Mathur 2013). Several different study interventions were used. Therefore, study population effect sizes were calculated as risk ratios.

\section{Agreements and disagreements with other studies or reviews}

Four meta-analyses on the use of adjunctive dexamethasone in adults were published, two in 2009 (Assiri 2009; Vardakas 2009) and two in 2012 (Borchorst 2012; Bernardo 2012). The first metaanalysis (Vardakas 2009) concluded that dexamethasone was associated with a non-significant decrease in mortality, but when the trial from Malawi was left out the decrease in mortality did reach significance. The reasons for excluding the Malawian trial were a HIV-positive population, high mortality, poor general status and low human development index (HDI) $(<0.5)$. However, other countries that were included had only slightly higher HDIs at the time of inclusion (Girgis 1989, Egypt 0.53; Bhaumik 1998 India 0.53, Scarborough 2007 Malawi 0.49). Several subgroup analyses showed that dexamethasone was most beneficial in patients with definite meningitis, in high- and medium-income countries and patients with a short duration of symptoms. Out of four analyses eight subgroups consisted of only one or two studies, limiting the value of the meta-analysis. Analyses on mortality and hearing loss in high- and medium-income countries were similar to our results. The study by Bennett 1963 was not included in this meta-analysis for unknown reasons. The second metaanalysis included four recent trials in adults (de Gans 2002; Nguyen 2007; Scarborough 2007; Thomas 1999) and concluded that dexamethasone reduced mortality in high-income countries (Assiri 2009). The third meta-analysis (Borchorst 2012) included 29 randomised studies and had similar conclusions as the Cochrane 2010 meta-analysis (Brouwer 2010a), which were that adjunctive dexamethasone was beneficial in adults in high-income countries, especially in patients with pneumococcal meningitis. The fourth meta-analysis (Bernardo 2012) included only paediatric studies and concluded that adjunctive dexamethasone was not associated with a reduction in mortality, hearing loss or sequelae (Bernardo 2012). The reason why seven studies included in the Cochrane 2013 updated meta-analysis were not included in the meta-analysis of paediatric studies was not specified (Brouwer 2013). According to the classification of study quality used, most of these studies were of similar quality to those that were included.

The difference in efficacy of corticosteroids between highand low-income countries was mainly driven by two large studies from Malawi (Molyneux 2002; Scarborough 2007), together representing $60 \%$ of included participants from low-income countries. Participants included in these studies were often HIV-positive, presented late in the disease course or received inappropriate antibiotic therapy (Molyneux 2002; Scarborough 2007). There may be several reasons for the difference in efficacy of corticosteroids such as delayed presentation, clinical severity, underlying anaemia, malnutrition, the antibiotics used, HIV infection or other unidentified differences between populations. Recently, genetic factors were suggested to influence the patient's response to corticosteroids (Brouwer 2012). A study compared characteristics of children with culture-positive communityacquired bacterial meningitis in the Children's Unit, Queen Elizabeth Central Hospital, Blantyre, Malawi and in the Royal
Liverpool Children's Hospital, UK from time periods before the introduction of vaccines (Molyneux 2006). Children in Malawi presented later and were more often comatose and malnourished, compared to children in Britain. Mortality from bacterial meningitis in children in Malawi was much higher than in children in Britain ( $41 \%$ versus $7 \%$ ), even when infected with the same organism. Several studies have shown that a delay in initiation of antibiotic treatment is associated with worse outcome in bacterial meningitis (McMillan 2001; Køster-Rasmussen 2008; Proulx 2005). A metaanalysis on timing of steroids with respect to initial symptoms could not be performed because outcome data were not specified for patients presenting early or late during clinical course in any of the studies. Nevertheless, we stress the need for early diagnosis and treatment.

A meta-analysis of individual patient data was performed with five large RCTs (de Gans 2002; Molyneux 2002; Nguyen 2007; Peltola 2007; Scarborough 2007; van de Beek 2010). Data from 2029 patients from five trials were included in the analysis (833 $(41.0 \%)$ aged $<15$ years). HIV infection was confirmed or likely in $580(28.6 \%)$ patients and bacterial meningitis was confirmed in 1639 (80.8\%). Dexamethasone was not associated with a significant reduction in death (270 of 1019 (26.5\%) on dexamethasone versus 275 of $1010(27.2 \%)$ on placebo; odds ratio (OR) $0.97,95 \% \mathrm{Cl}$ 0.79 to 1.19), death or severe neurological sequelae or bilateral severe deafness $(42.3 \%$ versus $44.3 \%$; OR $0.92,95 \% \mathrm{Cl} 0.76$ to $1.11)$, death or any neurological sequelae or any hearing loss (54.2\% versus $57.4 \%$; OR $0.89,95 \% \mathrm{Cl} 0.74$ to 1.07 ), or death or severe bilateral hearing loss $(36.4 \%$ versus $38.9 \%$; OR 0.89 , $95 \% \mathrm{Cl} 0.73$ to 1.69). However, dexamethasone reduced hearing loss among survivors (24.1\% versus $29.5 \%$; OR $0.77,95 \% \mathrm{Cl} 0.60$ to $0.99, \mathrm{P}=0.04)$. Dexamethasone had no effect in any of the pre-specified subgroups, including specific causative organisms, pre-dexamethasone antibiotic treatment, HIV status or age. The differences between Malawi and the other clinical settings call into question the appropriateness of summary measures that combine the results, even if statistical tests of heterogeneity are deemed acceptable. Mortality rates in the two studies from Malawi were three to five-fold higher than in the studies from Europe, South America and Vietnam (de Gans 2002; Molyneux 2002; Nguyen 2007; Peltola 2007; Scarborough 2007). In subgroups of the individual patient data meta-analysis, there were several instances in which the 12 statistic was more than $50 \%$, which indicates at least moderate heterogeneity (Mclntyre 2010). This current Cochrane review confirms the beneficial effect of corticosteroids on hearing loss that was found in the subgroups of the individual meta-analysis (van de Beek 2010). Treatment with adjunctive corticosteroids was not associated with harm. In order to establish with certainty whether or not dexamethasone has a place in the treatment of bacterial meningitis, a large multinational RCT in that subgroup would be necessary. Such a trial would need to include approximately 13,500 participants to show an odds ratio (OR) of 0.9 with a power of $90 \%$ in a population with $27 \%$ risk of death in the placebo group, and is therefore unlikely to be performed or finished in the next decade. Meanwhile, results of our analysis support the use of corticosteroids in children and adults with communityacquired bacterial meningitis in high-income countries.

\section{Implementation studies}

Seven studies evaluated the implementation of adjunctive dexamethasone treatment and its effect on the outcome of bacterial meningitis (Bodilsen 2014; Brouwer 2010b; Castelblanco 
2014; Cornelis 2011; Heckenberg 2012b; Koopmans 2013; Peterković 2012). Three studies compared the prognosis of adult pneumococcal, meningococcal and Listeria monocytogenes meningitis between two nationwide prospective cohort studies; one was performed before and the other after the implementation of adjunctive dexamethasone (Brouwer 2010b; Heckenberg 2012b; Koopmans 2013). The studies showed that after the introduction of adjunctive dexamethasone, $84 \%$ of patients with pneumococcal meningitis, $89 \%$ of adults with meningococcal meningitis and $53 \%$ of $L$ monocytogenes meningitis received the recommended four-day regimen ( $40 \mathrm{mg} /$ day in four doses). The mortality from pneumococcal meningitis decreased from $30 \%$ to $20 \%$ after the introduction of dexamethasone $(\mathrm{P}$ value $=0.001)$ and the rate of hearing loss decreased from $22 \%$ to $12 \%$ ( $P$ value $=0.001$ ) (Brouwer 2010b). Meningococcal disease mortality declined from $7 \%$ to $4 \%$ and hearing loss from $8 \%$ to $3 \%$, but these differences did not reach statistical significance (Heckenberg 2012b). No evidence of harm from dexamethasone was identified in studies on pneumococcal and meningococcal meningitis. The beneficial effect of dexamethasone on pneumococcal meningitis was similar to that identified in the European Dexamethasone Study (de Gans 2002). For listerial meningitis, an increase in unfavourable outcome from $27 \%$ to $61 \%$ was observed between the first and second cohort study (Koopmans 2013). In a multivariate analysis bacterial genotype was found to be the main cause of the poorer prognosis. Dexamethasone was not associated with a change in mortality, hearing loss or sequelae in listerial meningitis. However, as adjunctive dexamethasone treatment was another major change between cohorts, it was suggested to discontinue dexamethasone when $L$ monocytogenes is identified. A nationwide retrospective study from Denmark showed dexamethasone was administered to $60 \%$ of meningitis cases between 2008 and 2012 compared to 37\% between 2003 and 2007 (Bodilsen 2014). Dexamethasone treatment was associated with a significant decrease in the risk of an unfavourable outcome (33\% versus $53 \%)$ and mortality (15\% versus $24 \%$ ). The implementation studies provide additional (class III) evidence that adjunctive dexamethasone is beneficial in adults with bacterial meningitis in high-income countries.

In a population-based observational study from the USA, incidence and mortality of bacterial meningitis due to the five most common pathogens between 1997 and 2010 were studied in a network database (Castelblanco 2014). The study showed that over time mortality declined. This was attributed to the publication of the IDSA guideline of 2004, which advised adjunctive dexamethasone for all suspected bacterial meningitis cases (Castelblanco 2014). However, data on dexamethasone use were not available and therefore a causal relation could not be established.

Retrospective studies in Belgium and Croatia evaluated whether the use of dexamethasone improved prognosis in adults
(Peterković 2012), or both adults and children (Cornelis 2011). Both studies showed no effect of dexamethasone. However, in both studies the rationale to give or withhold dexamethasone was unclear and therefore confounding by indication (patients with severe sickness get more medication, i.e. dexamethasone, but still have a worse prognosis) is a major problem in these studies, as is the retrospective design.

\section{AUTHORS'CONCLUSIONS}

\section{Implications for practice}

In summary, the consistency and degree of benefit identified in this analysis merits the use of corticosteroids in adults and children with acute bacterial meningitis in high-income countries, although the strength of the evidence is not optimal. We recommend a four-day regimen of dexamethasone $(0.6 \mathrm{mg} / \mathrm{kg}$ daily) given before or with the first dose of antibiotics.

\section{Implications for research}

1. Although additional evidence from well-designed randomised controlled trials (RCTs) would be optimal, this is impractical for reasons of cost and logistics.

2. Further follow-up studies in countries where dexamethasone has been implemented may provide additional circumstantial evidence on the effectiveness of adjunctive dexamethasone.

3. The role of corticosteroids in neonatal meningitis is currently unclear due to the different spectrum of causative microorganisms and the lack of applicable RCT data. Additional RCTs in neonatal meningitis are needed.

4. Case series are needed to determine the effect of adjunctive dexamethasone therapy in patients with pneumococcal meningitis caused by highly penicillin- or cephalosporinresistant strains.

\section{ACKNOWLEDGEMENTS}

Diederik van de Beek is supported by grants from the Netherlands Organization for Health Research and Development (ZonMw; NWO Veni grant 2006 (916.76.023); NWO Vidi grant 2010 (016.116.358)), the Academic Medical Center (AMC Fellowship 2008) and European Research Council (ERC Starting Grant (281156)). Matthijs Brouwer is supported by a grant from the Netherlands Organization for Health Research and Development (ZonMw; NWO Veni grant 2012 (916.13.078)).

We wish to thank the following people for commenting on the 2010 updated review: Amy Zelmer, Andrew Herxheimer, Mark Coulthard, Mark Jones and Inge Axelsson. We also thank the following people for commenting on this 2013 updated review: Marilyn Bamford, Ram Yogev, Elaind Beller and Inge Axelsson. 


\section{R E F E R E N C E S}

\section{References to studies included in this review}

Bademosi 1979 \{published data only\}

Bademosi O, Osuntokun BO. Prednisolone in the treatment of pneumococcal meningitis. Tropical and Geographical Medicine 1979;31(1):53-6.

\section{Belsey 1969 \{published data only\}}

Belsey MA, Hoffpauir CW, Smith MH. Dexamethasone in the treatment of acute bacterial meningitis: the effect of study design on the interpretation of results. Pediatrics 1969;44(4):503-13.

\section{Bennett 1963 \{published data only\}}

Bennett IL, Finland M, Hamburger M, Kass EH, Lepper M, Waisbren BA. The effectiveness of hydrocortisone in the management of severe infections. JAMA 1963;183(6):462-5.

\section{Bhaumik 1998 \{published data only\}}

Bhaumik S, Behari M. Role of dexamethasone as adjunctive therapy in acute bacterial meningitis in adults. Neurology India 1998;46:225-8.

\section{Ciana 1995 \{published data only\}}

Ciana G, Parmar N, Antonio C, Pivetta S, Tamburlini G, Cuttini M. Effectiveness of adjunctive treatment with steroids in reducing short-term mortality in a high-risk population of children with bacterial meningitis. Journal of Tropical Pediatrics 1995;41(3):164-8.

\section{de Gans 2002 \{published data only\}}

de Gans J, van de Beek D. Dexamethasone in adults with bacterial meningitis. New England Journal of Medicine 2002;347(20):1549-56.

\section{DeLemos 1969 \{published data only\}}

DeLemos RA, Haggerty RJ. Corticosteroids as an adjunct to treatment in bacterial meningitis. A controlled clinical trial. Pediatrics 1969;44(1):30-4.

\section{Girgis 1989 \{published data only\}}

Girgis NI, Farid Z, Mikhail IA, Farrag I, Sultan Y, Kilpatrick ME. Dexamethasone treatment for bacterial meningitis in children and adults. Pediatric Infectious Disease Journal 1989;8(12):848-51.

\section{Kanra 1995 \{published data only\}}

Kanra GY, Ozen H, Secmeer G, Ceyhan M, Ecevit Z, Belgin E. Beneficial effects of dexamethasone in children with pneumococcal meningitis. Pediatric Infectious Disease Journal 1995;14(6):490-4.

\section{Kilpi 1995 \{published data only\}}

Kilpi T, Peltola H, Jauhiainen T, Kallio MJ. Oral glycerol and intravenous dexamethasone in preventing neurologic and audiologic sequelae of childhood bacterial meningitis. The Finnish Study Group. Pediatric Infectious Disease Journal 1995;14(4):270-8.
King 1994 \{published data only\}

King SM, Law B, Langley JM, Heurter H, Bremner D, Wang EE, et al. Dexamethasone therapy for bacterial meningitis: better never than late?. Canadian Journal of Infectious Diseases 1994;5:210-5.

\section{Lebel 1988a \{published data only\}}

Lebel MH, Freij BJ, Syrogiannopoulos GA, Chrane DF, Hoyt MJ, Stewart SM, et al. Dexamethasone therapy for bacterial meningitis. Results of two double-blind, placebo-controlled trials. New England Journal of Medicine 1988;319(15):964-71.

\section{Lebel 1988b \{published data only\}}

Lebel MH, Freij BJ, Syrogiannopoulos GA, Chrane DF, Hoyt MJ, Stewart SM, et al. Dexamethasone therapy for bacterial meningitis. Results of two double-blind, placebo-controlled trials. New England Journal of Medicine 1988;319(15):964-71.

\section{Lebel 1989 \{published data only\}}

Lebel MH, Hoyt MJ, Waagner DC, Rollins NK, Finitzo T, McCracken GH Jr, et al. Magnetic resonance imaging and dexamethasone therapy for bacterial meningitis. American Journal of Diseases of Children 1989;143(3):301-6.

\section{Mathur 2013 \{published data only\}}

* Mathur NB, Garg A, Mishra TK. Role of dexamethasone in neonatal meningitis: a randomized controlled trial. Indian Journal of Pediatrics 2013;80(2):102-7.

\section{Molyneux 2002 \{published data only\}}

Molyneux EM, Walsh AL, Forsyth H, Tembo M, Mwenechanya J, Kayira K, et al. Dexamethasone treatment in childhood bacterial meningitis in Malawi: a randomised controlled trial. Lancet 2002;360(9328):211-8.

Nguyen 2007 \{published data only\}

Nguyen TH, Tran TH, Thwaites G, Ly VC, Dinh XS, Ho Dang TN, et al. Dexamethasone in Vietnamese adolescents and adults with bacterial meningitis. New England Journal of Medicine 2007;357:2431-40.

\section{Odio 1991 \{published data only\}}

Odio CM, Faingezicht I, Paris M, Nassar M, Baltodano A, Rogers $\mathrm{J}$, et al. The beneficial effects of early dexamethasone administration in infants and children with bacterial meningitis. New England Journal of Medicine 1991;324(22):1525-31.

\section{Peltola 2007 \{published data only\}}

Peltola H, Roine I, Fernández J, Zavala I, Ayala SG, Mata AG, et al. Adjuvant glycerol and/or dexamethasone to improve the outcomes of childhood bacterial meningitis: a prospective, randomized, double-blind, placebo-controlled trial. Clinical Infectious Diseases 2007;45:1277-86.

\section{Qazi 1996 \{published data only\}}

Qazi SA, Khan MA, Mughal N, Ahmad M, Joomro B, Sakata Y, et al. Dexamethasone and bacterial meningitis in Pakistan. Archives of Disease in Childhood 1996;75(6):482-8. 
Sankar 2007 \{published data only\}

Sankar J, Singhi P, Bansal A, Ray P, Singhi S. Role of dexamethasone and oral glycerol in reducing hearing and neurological sequelae in children with bacterial meningitis. Indian Pediatrics 2007;44:649-56.

\section{Scarborough 2007 \{published data only\}}

Scarborough M, Gordon SB, Whitty CJ, French N, Njalale Y, Chitani A, et al. Corticosteroids for bacterial meningitis in adults in sub-Saharan Africa. New England Journal of Medicine 2007;357:2441-50.

\section{Schaad 1993 \{published data only\}}

Schaad UB, Lips U, Gnehm HE, Blumberg A, Heinzer I, Wedgwood J. Dexamethasone therapy for bacterial meningitis in children. Swiss Meningitis Study Group. Lancet 1993;342(8869):457-61.

\section{Thomas 1999 \{published data only\}}

Thomas R, Le Tulzo Y, Bouget J, Camus C, Michelet C, Le Corre P, et al. Trial of dexamethasone treatment for severe bacterial meningitis in adults. Adult Meningitis Steroid Group. Intensive Care Medicine 1999;25(5):475-80.

Wald 1995 \{published data only\}

Wald ER, Kaplan SL, Mason EOJ, Sabo D, Ross L, Arditi M, et al. Dexamethasone therapy for children with bacterial meningitis. Meningitis Study Group. Pediatrics 1995;95(1):21-8.

\section{References to studies excluded from this review}

Ayaz 2008 \{published data only\}

Ayaz C, Celen MK, Geyik MF, Ulug M. The efficacy of dexamethasone treatment in adult patients with acute bacterial meningitis. Neurosciences 2008;13:146-50.

\section{Baldy 1986 \{published data only\}}

Baldy JL, Passos JN. Dexamethasone in the treatment of meningococcal meningitis. Revista Paulista de Medicina 1986;104(2):61-5.

\section{Daoud 1999 \{published data only\}}

Daoud AS, Batieha A, Al-Sheyyab M, Abuekteish F, Obeidat A, Mahafza T. Lack of effectiveness of dexamethasone in neonatal bacterial meningitis. European Journal of Pediatrics 1999;158(3):230-3.

\section{Farina 1995 \{published data only\}}

Farina JSL, Alencastro R, Dalligna C, Rotta NT. Dexamethasone and bacterial meningitis: a randomised controlled trial in Brazilian children and a meta-analysis study. Neurology 1995;45(A349):45.

\section{Gijwani 2002 \{published data only\}}

Gijwani D, Kumhar MR, Singh VB, Chadda VS, Soni PK, Nayak KC, et al. Dexamethasone therapy for bacterial meningitis in adults: a double blind placebo control study. Neurology India 2002;50(1):63-7.
Gupta 1996 \{published data only\}

Gupta A, Singh NK. Dexamethasone in adults with bacterial meningitis. Journal of the Association of Physicians of India 1996;44(2):90-2.

\section{Jensen 1969 \{published data only\}}

Jensen K, Ranek L, Rosdahl N. Bacterial meningitis; a review of 356 cases with special reference to corticosteroid and antiserum treatment. Scandinavian Journal of Infectious Diseases 1969;1(1):21-30.

Lepper 1959 \{published data only\}

Lepper M, Spies HW. Treatment of pneumococcic meningitis. Archives of Internal Medicine 1959;104(3):253-9.

Marguet 1993 \{published data only\} Marguet C, Mallet $\mathrm{E}$. Value of dexamethasone in purulent meningitis in children. Apropos of a comparative study of 85 children. Archives Français Pediatrie 1993;50(2):111-7.

\section{Ozen 2006 \{published data only\}}

Ozen M, Kanra G, Kara A, Bakar EE, Ceyhan M, Secmeer G, et al. Long-term beneficial effects of dexamethasone on intellectual and neuropsychological outcome of children with pneumococcal meningitis. Scandinavian Journal of Infectious Diseases 2006;38(2):104-9.

\section{Passos 1979 \{published data only\}}

Passos JN, Baldy JL. Evaluation of the use of dexamethasone in the therapeutic schedule for purulent meningitis. Revista do Instituto de Medicina Tropical de São Paulo 1979;21(2):90-8.

Peltola 2004 \{unpublished data only\}

Peltola $\mathrm{H}$. Childhood bacterial meningitis relieved better by glycerol than dexamethasone. 44th ICAAC, Chicago. Chicago, 2004.

\section{Shembesh 1997 \{published data only\}}

Shembesh NM, Elbargathy SM, Kashbur IM, Rao BN, Mahmoud KS. Dexamethasone as an adjunctive treatment of bacterial meningitis. Indian Journal of Pediatrics 1997;64(4):517-22.

\section{Singhi 2008 \{published data only\}}

Singhi S, Järvinen A, Peltola H. Increase in serum osmolality is possible mechanism for the beneficial effects of glycerol in childhood bacterial meningitis. Pediatric Infectious Disease Journal 2008;27:892-6.

\section{Syrogiannopoulos 1994 \{published data only\}}

Syrogiannopoulos GA, Lourida AN, Theodoridou MC, Pappas IG, Babilis, GC, Economidis JJ, et al. Dexamethasone therapy for bacterial meningitis in children: 2- versus 4-day regimen. Journal of Infectious Diseases 1994;169(4):853-8.

\section{Tolaj 2010 \{published data only\}}

Tolaj I, Dreshaj S, Qehaja E, Tolaj J, Doda-Ejupi T, Mehmeti M. Dexamethasone as adjuvant therapy in the treatment of invasive meningococcal diseases. Medicinski Arhiv 2010;64(4):228-30. 


\section{Additional references}

\section{Assiri 2009}

Assiri AM, Alasmari FA, Zimmerman VA, Baddour LM, Erwin PJ, Tleyjeh IM. Corticosteroid administration and outcome of adolescents and adults with acute bacterial meningitis: a metaanalysis. Mayo Clinic Proceedings 2009;84(5):403-9.

\section{Balis 1987}

Balis FM, Lester CM, Chrousos GP, Heideman RL, Poplack DG. Differences in cerebrospinal fluid penetration of corticosteroids: possible relationship to the prevention of meningeal leukemia. Journal of Clinical Oncology 1987;5:202-7.

\section{Baraff 1993}

Baraff LJ, Lee SI, Schriger DL. Outcomes of bacterial meningitis in children: a meta-analysis. Pediatric Infectious Disease Journal 1993;12(5):389-94.

\section{Bernardo 2012}

Bernardo WM, Aires FT, Sá FP. Effectiveness of the association of dexamethasone with antibiotic therapy in pediatric patients with bacterial meningitis. Revista da Associação Médica Brasileira 2012;58(3):319-22.

\section{Bodilsen 2014}

Bodilsen J, Dalager-Pedersen M, Schønheyder HC, Nielsen H. Dexamethasone treatment and prognostic factors in community-acquired bacterial meningitis: a Danish retrospective population-based cohort study. Scandinavian Journal of Infectious Diseases 2014;46:418-25.

\section{Bohr 1983}

Bohr V, Hansen B, Jessen O, Johnsen N, Kjersem H, Kristensen HS, et al. Eight hundred and seventy-five cases of bacterial meningitis. Part I of a three-part series: clinical data, prognosis, and the role of specialised hospital departments. Journal of Infection 1983;7(1):21-30.

\section{Borchorst 2012}

Borchorst S, Moller $\mathrm{K}$. The role of dexamethasone in the treatment of bacterial meningitis - a systematic review. Acta Anaesthesiologica Scandinavica 2012;56:1210-21.

\section{Brouwer 2010b}

Brouwer MC, Heckenberg SG, de Gans J, Spanjaard L, Reitsma JB, van de Beek D. Nationwide implementation of adjunctive dexamethasone therapy for pneumococcal meningitis. Neurology 2010;75(17):1533-9.

\section{Brouwer 2010c}

Brouwer MC, Tunkel AR, van de Beek D. Epidemiology, diagnosis, and antimicrobial treatment of acute bacterial meningitis. Clinical Microbiology Reviews 2010;23(3):467-92.

\section{Brouwer 2012}

Brouwer MC, van der Ende A, Baas F, van de Beek D. Genetic variation in $\mathrm{GLCCl} 1$ and dexamethasone in bacterial meningitis. Journal of Infection 2012;65(5):465-7.

\section{Castelblanco 2014}

Castelblanco RL, Lee M, Hasbun R. Epidemiology of bacterial meningitis in the USA from 1997 to 2010: a population-based observational study. Lancet Infectious Diseases 2014;14:813-9.

\section{Cornelis 2011}

Cornelis AS, Hachimi-Idrissi S. The use of dexamethasone in bacterial meningitis in children and adults: a retrospective analysis. ISRN Pediatrics 2011;2011:380283.

\section{Fritz 2012}

Fritz D, Brouwer MC, van de Beek D. Dexamethasone and long-term survival in bacterial meningitis. Neurology 2012;79(22):2177-9.

\section{Geiman 1992}

Geiman BJ, Smith AL. Dexamethasone and bacterial meningitis. A meta-analysis of randomized clinical trials. Western Journal of Medicine 1992;157:27-31.

\section{Glasziou 1995}

Glasziou PP, Irwig LM. An evidence based approach to individualising treatment. BMJ 1995;311(7016):1356-9.

\section{Havens 1989}

Havens PL, Wendelberger KJ, Hoffman GM, Lee MB, Chusid MJ. Corticosteroids as adjunctive therapy in bacterial meningitis. A meta-analysis of clinical trials. American Journal of Diseases of Children 1989;143:1051-5.

\section{Heckenberg 2012a}

Heckenberg SG, Brouwer MC, van der Ende A, Hensen EF, van de Beek D. Hearing loss in adults surviving pneumococcal meningitis is associated with otitis and pneumococcal serotype. Clinical Microbiology and Infection 2012;18(9):849-55.

\section{Heckenberg 2012b}

Heckenberg SG, Brouwer MC, van der Ende A, van de Beek D. Adjunctive dexamethasone in adults with meningococcal meningitis. Neurology 2012;79(15):1563-9.

\section{Higgins 2011}

Higgins JPT, Green S (editors). Cochrane Handbook for Systematic Reviews of Interventions. Version 5.1.0 [updated March 2011]. The Cochrane Collaboration, 2011. Available from www.cochrane-handbook.org. Chichester, UK: Wiley-Blackwell.

\section{Klugman 1995}

Klugman KP, Friedland IR, Bradley JS. Bactericidal activity against cephalosporin-resistant Streptococcus pneumoniae in cerebrospinal fluid of children with acute bacterial meningitis. Antimicrobial Agents and Chemotherapy 1995;39(9):1988-92.

\section{Koopmans 2013}

Koopmans MM, Brouwer MC, Bijlsma MW, Bovenkerk S, Keijzers W, van der Ende A, et al. Listeria monocytogenes sequence type 6 and increased rate of unfavorable outcome in meningitis: epidemiologic cohort study. Clinical Infectious Diseases 2013;57:247-53. 


\section{Køster-Rasmussen 2008}

Køster-Rasmussen R, Korshin A, Meyer CN. Antibiotic treatment delay and outcome in acute bacterial meningitis. Journal of Infection 2008;57:449-54.

\section{Lefebvre 2011}

Lefebvre C, Manheimer E, Glanville J. Chapter 6: Searching for studies. In: Higgins JPT, Green S (editors). Cochrane Handbook for Systematic Reviews of Interventions Version 5.1.0 [updated March 2011]. The Cochrane Collaboration, 2011. Available from www.cochrane-handbook.org.

\section{Lutsar 2003}

Lutsar I, Friedland IR, Jafri HS, Wubbel L, Ahmed A, Trujillo M, et al. Factors influencing the anti-inflammatory effect of dexamethasone therapy in experimental pneumococcal meningitis. Journal of Antimicrobial Chemotherapy 2003;52(4):651-5.

\section{McIntyre 1997}

McIntyre PB, Berkey CS, King SM, Schaad UB, Kilpi T, Kanra GY, et al. Dexamethasone as adjunctive therapy in bacterial meningitis. A meta-analysis of randomized clinical trials since 1988. JAMA 1997;278(11):925-31.

\section{McIntyre 2010}

McIntyre P. Adjunctive dexamethasone in meningitis: does value depend on clinical setting?. Lancet Neurology 2010;9:229-31.

\section{McIntyre 2012}

McIntyre PB, O'Brien KL, Greenwood B, van de Beek D. Effect of vaccines on bacterial meningitis world-wide. Lancet 2012;380(9854):1703-11.

\section{McMillan 2001}

McMillan DA, Lin CY, Aronin SI, Quagliarello VJ. Communityacquired bacterial meningitis in adults: categorization of causes and timing of death. Clinical Infectious Diseases 2001;33:969-75.

\section{Molyneux 2006}

Molyneux E, Riordan FA, Walsh A. Acute bacterial meningitis in children presenting to the Royal Liverpool Children's Hospital, Liverpool, UK and the Queen Elizabeth Central Hospital in Blantyre, Malawi: a world of difference. Annals of Tropical Paediatrics 2006;26(1):29-37.

\section{Peltola 2000}

Peltola H. Worldwide Haemophilus influenzae type B disease at the beginning of the 21st century: global analysis of the disease burden 25 years after the use of the polysaccharide vaccine and a decade after the advent of conjugates. Clinical Microbiology Reviews 2000;13(2):302-17.

\section{Peterković 2012}

Peterković V, Trkulja V, Kutleša M, Krajinović V, Lepur D. Dexamethasone for adult community-acquired bacterial meningitis: 20 years of experience in daily practice. Journal of Neurology 2012;259(2):225-36.

\section{Prasad 1995}

Prasad K, Haines T. Dexamethasone treatment for acute bacterial meningitis: how strong is the evidence for routine use?. Journal of Neurology, Neurosurgery and Psychiatry 1995;59(1):31-7.

\section{Proulx 2005}

Proulx N, Fréchette D, Toye B, Chan J, Kravcik S. Delays in the administration of antibiotics are associated with mortality from adult acute bacterial meningitis. QJM 2005;94:291-8.

\section{RevMan 2014 [Computer program]}

The Nordic Cochrane Centre, The Cochrane Collaboration. Review Manager (RevMan). Version 5.3. Copenhagen: The Nordic Cochrane Centre, The Cochrane Collaboration, 2014.

\section{Ricard 2007}

Ricard JD, Wolff M, Lacherade JC, Mourvillier B, Hidri N, Barnaud $\mathrm{G}$, et al. Levels of vancomycin in cerebrospinal fluid of adult patients receiving adjunctive corticosteroids to treat pneumococcal meningitis: a prospective multicenter observational study. Clinical Infectious Diseases 2007;44:250-5.

\section{Sapolsky 1985}

Sapolsky RM, Pulsinelli WA. Glucocorticoids potentiate ischemic injury to neurons: therapeutic implications. Science 1985;229(4720):1397-400.

\section{Scheld 1980}

Scheld WM, Dacey RG, Winn HR, Welsh JE, Jane JA, Sande MA. Cerebrospinal fluid outflow resistance in rabbits with experimental meningitis. Alterations with penicillin and methylprednisolone. Journal of Clinical Investigation 1980;66(2):243-53.

\section{Tauber 1985}

Tauber MG, Khayam-Bashi H, Sande MA. Effects of ampicillin and corticosteroids on brain water content, cerebrospinal fluid pressure, and cerebrospinal fluid lactate levels in experimental pneumococcal meningitis. Journal of Infectious Diseases 1985;151(3):528-34.

\section{Török 2011}

Török ME, Nguyen DB, Tran TH, Nguyen TB, Thwaites GE, Hoang TQ, et al. Dexamethasone and long-term outcome of tuberculous meningitis in Vietnamese adults and adolescents. PLoS One 2011;6(12):e27821.

\section{UNHDI 2009}

United Nations Human Development Index. Human Development Index. http://hdr.undp.org/en/statistics/ 2009 (accessed 25 November 2009).

\section{van de Beek 2002}

van de Beek D, Schmand B, De Gans J, Weisfelt M, Vaessen H, Dankert J, et al. Cognitive impairment in adults with good recovery after bacterial meningitis. Journal of Infectious Diseases 2002;186(7):1047-52. 


\section{van de Beek 2004a}

van de Beek D, de Gans J. Dexamethasone and pneumococcal meningitis. Annals of Internal Medicine 2004;141(4):327.

\section{van de Beek 2004b}

van de Beek D, de Gans J, Spanjaard L, Weisfelt M, Reitsma JB, Vermeulen M. Clinical features and prognostic factors in adults with bacterial meningitis. New England Journal of Medicine 2004;351(18):1849-59.

\section{van de Beek 2006a}

van de Beek D, de Gans J, Tunkel AR, Wijdicks EFM. Communityacquired bacterial meningitis in adults. New England Journal of Medicine 2006;354(1):44-53. [MEDLINE: 16394301]

\section{van de Beek 2006b}

van de Beek D, de Gans J. Dexamethasone in adults with community-acquired bacterial meningitis. Drugs 2006;66(4):415-27

\section{van de Beek 2010}

van de Beek D, Farrar JJ, de Gans J, Mai NT, Molyneux EM, Peltola $\mathrm{H}$, et al. Adjunctive dexamethasone in bacterial meningitis: a meta-analysis of individual patient data. Lancet Neurology 2010;9:254-63.

\section{Vardakas 2009}

Vardakas KZ, Matthaiou DK, Falagas ME. Adjunctive dexamethasone therapy for bacterial meningitis in adults: a meta-analysis of randomized controlled trials. European Journal of Neurology 2009;16:662-73.

\section{Viladrich 1991}

Viladrich PF, Gudiol F, Linares J, Pallares R, Sabate I, Rufi G, et al. Evaluation of vancomycin for therapy of adult pneumococcal meningitis. Antimicrobial Agents and Chemotherapy

1991;35(12):2467-72.

\section{CHARACTERISTICS OF STUDIES}

Characteristics of included studies [ordered by study ID]

\section{Weisfelt 2006}

Weisfelt M, Hoogman M, van de Beek D, de Gans J, Dresschler WA, Schmand B. Dexamethasone and longterm outcome in adults with bacterial meningitis. Annals of Neurology 2006;60(4):456-68.

\section{References to other published versions of this review}

\section{Beek 1999}

Beek D van de, Gans J de, McIntyre P, Prasad K. Corticosteroids as adjunctive therapy in acute bacterial meningitis.

Cochrane Database of Systematic Reviews 1998, Issue 3. [DOI: 10.1002/14651858.CD001170]

\section{Brouwer 2010a}

Brouwer MC, McIntyre P, de Gans J, Prasad K, van de Beek D. Corticosteroids for acute bacterial meningitis. Cochrane Database of Systematic Reviews 2010, Issue 9. [DOI: 10.1002/14651858.CD004405.pub3]

\section{Brouwer 2013}

Brouwer MC, McIntyre P, Prasad K, van de Beek D. Corticosteroids for acute bacterial meningitis. Cochrane Database of Systematic Reviews 2013, Issue 6. [DOI: 10.1002/14651858.CD004405.pub4]

\section{van de Beek 2003}

van de Beek D, de Gans J, McIntyre P, Prasad K. Corticosteroids in acute bacterial meningitis. Cochrane Database of Systematic Reviews 2003, Issue 3. [DOI: 10.1002/14651858.CD004405.pub2]

\section{van de Beek 2007}

van de Beek D, de Gans J, McIntyre P, Prasad K. Corticosteroids for acute bacterial meningitis. Cochrane Database of Systematic Reviews 2007, Issue 1. [DOI: 10.1002/14651858.CD004405.pub2]

* Indicates the major publication for the study

\section{Bademosi 1979}

\begin{tabular}{ll}
\hline Methods & Randomised, unblinded \\
\hline Participants & $\begin{array}{l}10 \text { to } 59 \text { years; bacteriologically proven pneumococcal meningitis; } 52 \text { participants (27 male, } 25 \text { female; } \\
24 \text { received steroids, } 28 \text { placebo); Nigeria }\end{array}$ \\
\hline Interventions & Hydrocortisone, $100 \mathrm{mg}$; followed by prednisolone $60 \mathrm{mg} / \mathrm{d}$, $14 \mathrm{~d}$; before or with antibiotics (AB) \\
\hline Outcomes & Mortality \\
\hline Notes & AB - sulf/pen, mortality $44 \%$ \\
& Funding - not reported
\end{tabular}


Bademosi 1979 (Continued)

\begin{tabular}{|c|c|c|}
\hline Bias & Authors' judgement & Support for judgement \\
\hline $\begin{array}{l}\text { Random sequence genera- } \\
\text { tion (selection bias) }\end{array}$ & Unclear risk & Randomisation procedure is not specified \\
\hline $\begin{array}{l}\text { Allocation concealment } \\
\text { (selection bias) }\end{array}$ & High risk & The treatment allocation is not concealed \\
\hline $\begin{array}{l}\text { Blinding (performance } \\
\text { bias and detection bias) } \\
\text { All outcomes }\end{array}$ & High risk & The study is not blinded \\
\hline $\begin{array}{l}\text { Incomplete outcome data } \\
\text { (attrition bias) } \\
\text { All outcomes }\end{array}$ & High risk & Incomplete outcome data not addressed \\
\hline $\begin{array}{l}\text { Selective reporting (re- } \\
\text { porting bias) }\end{array}$ & Unclear risk & No information provided \\
\hline Other bias & High risk & Limited data presented; unevenly distributed severity of disease \\
\hline
\end{tabular}

\section{Belsey 1969}

\begin{tabular}{ll}
\hline Methods & Randomised, double-blind \\
\hline Participants & 0 to 17 years; purulent meningitis; 86 participants (40 male, 46 female; 43 DXM, 43 placebo; USA \\
\hline Interventions & DXM $1.2 \mathrm{mg} / \mathrm{m}^{2} / \mathrm{d}, 4 \mathrm{~d}$; timing unclear \\
\hline Outcomes & Mortality, hearing loss, adverse events (herpes zoster infections) \\
\hline Notes & $\begin{array}{l}\text { AB - chlor/sulf/pen, mortality } 3 \% \\
\text { Other - matching of patients and controls in } 48 \text { categories } \\
\end{array}$ \\
\hline
\end{tabular}

\section{Risk of bias}

\begin{tabular}{lll}
\hline Bias & Authors' judgement & Support for judgement \\
\hline $\begin{array}{l}\text { Random sequence genera- } \\
\text { tion (selection bias) }\end{array}$ & Unclear risk & Randomisation procedure not specified \\
\hline $\begin{array}{l}\text { Allocation concealment } \\
\text { (selection bias) }\end{array}$ & Unclear risk & No information on allocation concealment is provided \\
\hline $\begin{array}{l}\text { Blinding (performance } \\
\text { bias and detection bias) } \\
\text { All outcomes }\end{array}$ & Low risk & Double-blinded trial \\
\hline $\begin{array}{l}\text { Incomplete outcome data } \\
\text { (attrition bias) } \\
\text { All outcomes }\end{array}$ & High risk & Incomplete outcome data not addressed \\
\hline
\end{tabular}


Belsey 1969 (Continued)

Selective reporting (reporting bias)

High risk

16 randomised patients that could not be matched were not included; patients dying $<18$ hours of hospitalisation were excluded from the analysis. No intention-to-treat analysis

Bennett 1963

\begin{tabular}{ll}
\hline Methods & Randomised, double-blind \\
\hline Participants & $\begin{array}{l}\text { All ages; life-threatening infectious diseases, subgroup meningitis; } 85 \text { participants (gender not reported } \\
\text { for meningitis subgroup; 38 hydrocortisone/47 placebo); USA }\end{array}$ \\
\hline Interventions & Hydrocortisone scheme, $7 \mathrm{~d}$; after AB \\
\hline Outcomes & Mortality \\
\hline Notes & AB - not specified, mortality 45\% \\
& Funding - not reported \\
\hline
\end{tabular}

\section{Risk of bias}

Bias

Authors' judgement Support for judgement

Random sequence genera- Unclear risk Randomisation procedure not specified

tion (selection bias)

\begin{tabular}{|c|c|c|}
\hline $\begin{array}{l}\text { Allocation concealment } \\
\text { (selection bias) }\end{array}$ & Low risk & Allocation was concealed \\
\hline $\begin{array}{l}\text { Blinding (performance } \\
\text { bias and detection bias) } \\
\text { All outcomes }\end{array}$ & Low risk & The study was double-blind \\
\hline $\begin{array}{l}\text { Incomplete outcome data } \\
\text { (attrition bias) } \\
\text { All outcomes }\end{array}$ & High risk & Incomplete outcome data not addressed \\
\hline $\begin{array}{l}\text { Selective reporting (re- } \\
\text { porting bias) }\end{array}$ & High risk & $\begin{array}{l}\text { No intention-to-treat analysis for suspected bacterial meningitis patients. } \\
\text { Selection of culture-proven bacterial meningitis patients from a large cohort of } \\
\text { severely ill patients }\end{array}$ \\
\hline Other bias & Unclear risk & $\begin{array}{l}\text { Baseline characteristics and treatment specifications of DXM and control } \\
\text { groups are not reported }\end{array}$ \\
\hline
\end{tabular}

Bhaumik 1998

\begin{tabular}{ll}
\hline Methods & Randomised, unblinded \\
\hline Participants & $\begin{array}{l}12 \text { to } 75 \text { years; suspected bacterial meningitis with CSF criteria; } 30 \text { participants (26 male, } 4 \text { female; } 14 \\
\text { DXM, } 16 \text { placebo); India }\end{array}$ \\
\hline
\end{tabular}


Bhaumik 1998 (Continued)

\begin{tabular}{ll} 
Interventions & DXM $16 \mathrm{mg} /$ day, $4 \mathrm{~d}$, plus $3 \mathrm{~d}$ scheme; after AB \\
\hline Outcomes & Mortality, neurological sequelae, adverse events (not specified) \\
\hline Notes & AB - pen/chlor or ceph, mortality $13 \%$ \\
& Funding - not reported
\end{tabular}

\section{Risk of bias}

\begin{tabular}{lll}
\hline Bias & Authors' judgement & Support for judgement \\
\hline $\begin{array}{l}\text { Random sequence genera- } \\
\text { tion (selection bias) }\end{array}$ & Low risk & Randomised table chart \\
\hline $\begin{array}{l}\text { Allocation concealment } \\
\text { (selection bias) }\end{array}$ & High risk & The treatment allocation was not concealed \\
\hline $\begin{array}{l}\text { Blinding (performance } \\
\text { bias and detection bias) } \\
\text { All outcomes }\end{array}$ & High risk & The study is not blinded \\
\hline $\begin{array}{l}\text { Incomplete outcome data } \\
\text { (attrition bias) } \\
\text { All outcomes }\end{array}$ & High risk & Incomplete outcome data not addressed \\
\hline $\begin{array}{l}\text { Selective reporting (re- } \\
\text { porting bias) }\end{array}$ & Unclear risk & No intention-to-treat analysis \\
\hline \begin{tabular}{l} 
Other bias \\
\hline
\end{tabular} & High risk & Unevenly distributed baseline and clinical characteristics \\
\hline
\end{tabular}

\section{Ciana 1995}

\begin{tabular}{ll}
\hline Methods & Randomised, unblinded \\
\hline Participants & $\begin{array}{l}\text { 2 months to } 6 \text { years; suspected bacterial meningitis with CSF criteria; } 70 \text { participants (gender not re- } \\
\text { ported; } 34 \text { DXM, } 36 \text { placebo); Mozambique }\end{array}$ \\
\hline Interventions & DXM 0.4 mg/kg, $3 \mathrm{~d}$; timing unclear \\
\hline Outcomes & Mortality, neurological sequelae, adverse events (recurrent fever) \\
\hline Notes & AB - ampi/chlor, mortality 28\% \\
& Funding - not reported
\end{tabular}

\section{Risk of bias}

\begin{tabular}{lll}
\hline Bias & Authors' judgement & Support for judgement \\
\hline $\begin{array}{l}\text { Random sequence genera- } \\
\text { tion (selection bias) }\end{array}$ & Unclear risk & Randomisation procedure not specified \\
\hline $\begin{array}{l}\text { Allocation concealment } \\
\text { (selection bias) }\end{array}$ & High risk & The treatment allocation was not concealed \\
\hline
\end{tabular}


Ciana 1995 (Continued)

Blinding (performance $\quad$ High risk
bias and detection bias)

All outcomes

\begin{tabular}{lll}
\hline $\begin{array}{l}\text { Incomplete outcome data } \\
\text { (attrition bias) } \\
\text { All outcomes }\end{array}$ & High risk & Incomplete outcome data not addressed \\
\hline $\begin{array}{l}\text { Selective reporting (re- } \\
\text { porting bias) }\end{array}$ & High risk & $\begin{array}{l}\text { Patient retrospectively excluded because of different diagnosis; high number } \\
\text { of comatose patients compared to other trials. No intention-to-treat analysis }\end{array}$ \\
\hline Other bias & Unclear risk & Limited clinical data available \\
\hline
\end{tabular}

\section{de Gans 2002}

\begin{tabular}{ll}
\hline Methods & Randomised, double-blind \\
\hline Participants & $\begin{array}{l}\text { Older than } 16 \text { years; suspected bacterial meningitis with CSF criteria; } 301 \text { participants (169 male, } 132 \\
\text { female; } 157 \text { DXM and } 144 \text { placebo); Netherlands, Belgium, Denmark, Austria, Germany }\end{array}$ \\
\hline
\end{tabular}

\begin{tabular}{ll}
\hline Interventions & DXM $40 \mathrm{mg} / \mathrm{d}, 4 \mathrm{~d}$; before or with $\mathrm{AB}$ \\
\hline Outcomes & $\begin{array}{l}\text { Mortality, neurological sequelae, adverse events (herpes zoster/fungal infections, gastrointestinal } \\
\text { bleeding, hyperglycaemia) }\end{array}$ \\
\hline Notes & $\mathrm{AB}$ - various, mortality $11 \%$ \\
& Funding - NV Organon provided study medication (pharmaceutical company) \\
\hline
\end{tabular}

\section{Risk of bias}

\begin{tabular}{|c|c|c|}
\hline Bias & Authors' judgement & Support for judgement \\
\hline $\begin{array}{l}\text { Random sequence genera- } \\
\text { tion (selection bias) }\end{array}$ & Low risk & Computer-generated randomisation list, block size 6 \\
\hline $\begin{array}{l}\text { Allocation concealment } \\
\text { (selection bias) }\end{array}$ & Low risk & Allocation was concealed \\
\hline $\begin{array}{l}\text { Blinding (performance } \\
\text { bias and detection bias) } \\
\text { All outcomes }\end{array}$ & Low risk & The study was double-blind \\
\hline $\begin{array}{l}\text { Incomplete outcome data } \\
\text { (attrition bias) } \\
\text { All outcomes }\end{array}$ & Low risk & No loss to follow-up \\
\hline $\begin{array}{l}\text { Selective reporting (re- } \\
\text { porting bias) }\end{array}$ & Low risk & Inclusion chart provided. Intention-to-treat analysis \\
\hline Other bias & Low risk & No indication of other bias \\
\hline
\end{tabular}


DeLemos 1969

\begin{tabular}{ll}
\hline Methods & Randomised, double-blind \\
\hline Participants & $\begin{array}{l}1 \text { month to } 17 \text { years; diagnosis bacterial meningitis; } 117 \text { participants (gender not reported; } 54 \text { methyl- } \\
\text { prednisolone, } 63 \text { placebo); USA }\end{array}$ \\
\hline Interventions & Methylprednisolone $120 \mathrm{mg} / \mathrm{d}, 3 \mathrm{~d}$; after AB \\
\hline Outcomes & Mortality \\
\hline Notes & $\mathrm{AB}$ - chlor/sulf/pen, mortality $3 \%$ \\
& Funding - not reported
\end{tabular}

\section{Risk of bias}

\begin{tabular}{|c|c|c|}
\hline Bias & Authors' judgement & Support for judgement \\
\hline $\begin{array}{l}\text { Random sequence genera- } \\
\text { tion (selection bias) }\end{array}$ & Low risk & Randomised, block size 12 \\
\hline $\begin{array}{l}\text { Allocation concealment } \\
\text { (selection bias) }\end{array}$ & Low risk & Allocation was concealed \\
\hline $\begin{array}{l}\text { Blinding (performance } \\
\text { bias and detection bias) } \\
\text { All outcomes }\end{array}$ & Low risk & The study was double-blind \\
\hline $\begin{array}{l}\text { Incomplete outcome data } \\
\text { (attrition bias) } \\
\text { All outcomes }\end{array}$ & Low risk & Incomplete outcome data addressed \\
\hline $\begin{array}{l}\text { Selective reporting (re- } \\
\text { porting bias) }\end{array}$ & High risk & No intention-to-treat analysis \\
\hline Other bias & High risk & Antibiotic pretreatment unevenly distributed between randomisation arms \\
\hline
\end{tabular}

Girgis 1989

\begin{tabular}{ll}
\hline Methods & Randomised, unblinded \\
\hline Participants & $\begin{array}{l}\text { 3 months to 70 years; diagnosis bacterial meningitis; } 470 \text { participants (gender specified 429 - 278 male, } \\
151 \text { female; 225 DXM, 245 placebo); Egypt }\end{array}$ \\
\hline Interventions & DXM 16 to $24 \mathrm{mg} / \mathrm{d}, 4 \mathrm{~d}$; before or with AB \\
\hline Outcomes & Mortality, hearing loss, neurological sequelae \\
\hline Notes & AB - chlor/ampi, mortality 15\% \\
& $\begin{array}{l}\text { Funding - United States naval medical research and development command (government funding } \\
\text { body) }\end{array}$ \\
\hline
\end{tabular}

\section{Risk of bias}


Girgis 1989 (Continued)

\begin{tabular}{lll}
$\begin{array}{l}\text { Random sequence genera- } \\
\text { tion (selection bias) }\end{array}$ & Low risk & Pre-designed randomisation chart \\
\hline $\begin{array}{l}\text { Allocation concealment } \\
\text { (selection bias) }\end{array}$ & High risk & The treatment allocation was not concealed \\
\hline $\begin{array}{l}\text { Blinding (performance } \\
\text { bias and detection bias) } \\
\text { All outcomes }\end{array}$ & High risk & Study was not blinded \\
\hline $\begin{array}{l}\text { Incomplete outcome data } \\
\text { (attrition bias) } \\
\text { All outcomes }\end{array}$ & High risk & Incomplete outcome data not addressed \\
\hline $\begin{array}{l}\text { Selective reporting (re- } \\
\text { porting bias) }\end{array}$ & High risk & No intention-to-treat analysis \\
\hline $\begin{array}{l}\text { Other bias } \\
\text { High risk }\end{array}$ & $\begin{array}{l}\text { The very high number of comatose patients compared to other studies sug- } \\
\text { gests a selection bias }\end{array}$ \\
\hline
\end{tabular}

\section{Kanra 1995}

\begin{tabular}{ll}
\hline Methods & Randomised, double-blind \\
\hline Participants & $\begin{array}{l}2 \text { to } 6 \text { years; bacteriologically proven pneumococcal meningitis; } 53 \text { participants (32 male, } 21 \text { female; } 27 \\
\text { DXM, } 26 \text { no dexamethasone); Turkey }\end{array}$ \\
\hline Interventions & DXM $0.6 \mathrm{mg} / \mathrm{kg} / \mathrm{d}, 4 \mathrm{~d}$; before or with AB \\
\hline Outcomes & Mortality, hearing loss, neurological sequelae, adverse events (recurrent fever) \\
\hline Notes & AB - sulf/ampi, mortality $5 \%$ \\
& Funding - not reported \\
\hline
\end{tabular}

\section{Risk of bias}

\begin{tabular}{lll}
\hline Bias & Authors' judgement & Support for judgement \\
\hline $\begin{array}{l}\text { Random sequence genera- } \\
\text { tion (selection bias) }\end{array}$ & Low risk & Computer-generated randomisation list \\
\hline $\begin{array}{l}\text { Allocation concealment } \\
\text { (selection bias) }\end{array}$ & Low risk & Allocation was concealed \\
\hline $\begin{array}{l}\text { Blinding (performance } \\
\text { bias and detection bias) }\end{array}$ & Low risk & Study was double-blind \\
$\begin{array}{l}\text { All outcomes } \\
\begin{array}{l}\text { Incomplete outcome data } \\
\text { (attrition bias) } \\
\text { All outcomes }\end{array}\end{array}$ & High risk & Incomplete outcome data not addressed \\
\hline $\begin{array}{l}\text { Selective reporting (re- } \\
\text { porting bias) }\end{array}$ & High risk & No intention-to-treat analysis; selection of pneumococcal meningitis patients \\
\hline
\end{tabular}


Kanra 1995 (Continued)
Other bias
High risk
Unevenly distributed severity of disease (Glasgow Coma Scale) at admission
(control group better)

Kilpi 1995

\begin{tabular}{ll}
\hline Methods & Randomised, unblinded \\
\hline Participants & $\begin{array}{l}\text { 3 months to } 15 \text { years; suspected bacterial meningitis with CSF criteria; } 58 \text { participants (gender not re- } \\
\text { ported; } 32 \mathrm{DXM}, 26 \text { placebo); Finland }\end{array}$ \\
\hline Interventions & DXM $1.5 \mathrm{mg} / \mathrm{kg} / \mathrm{d}, 3 \mathrm{~d}$; before or with AB \\
\hline Outcomes & Mortality, hearing loss, neurological sequelae, adverse events (gastrointestinal bleeding) \\
\hline Notes & AB - ceph, mortality 2\% \\
& Other - trial also evaluated adjunctive glycerol and combined adjunctive glycerol and DXM therapy \\
& Funding - Arvo and Leo Ylppö foundation (charity) \\
\hline
\end{tabular}

\section{Risk of bias}

\begin{tabular}{lll}
\hline Bias & Authors' judgement & Support for judgement \\
\hline $\begin{array}{l}\text { Random sequence genera- } \\
\text { tion (selection bias) }\end{array}$ & Low risk & Computer-generated list of random therapy assignments \\
\hline $\begin{array}{l}\text { Allocation concealment } \\
\text { (selection bias) }\end{array}$ & High risk & The treatment allocation was not concealed \\
\hline $\begin{array}{l}\text { Blinding (performance } \\
\text { bias and detection bias) } \\
\text { All outcomes }\end{array}$ & High risk & Study was not blinded \\
\hline $\begin{array}{l}\text { Incomplete outcome data } \\
\text { (attrition bias) } \\
\text { All outcomes }\end{array}$ & Low risk & Incomplete outcome data addressed \\
\hline $\begin{array}{l}\text { Selective reporting (re- } \\
\text { porting bias) }\end{array}$ & High risk & No intention-to-treat analysis \\
\hline $\begin{array}{l}\text { Other bias } \\
\text { High risk }\end{array}$ & & $\begin{array}{l}\text { High number of pre-treated patients compared to other studies. Unevenly dis- } \\
\text { tributed between randomisation arms }\end{array}$ \\
\hline
\end{tabular}

King 1994

\begin{tabular}{ll}
\hline Methods & Randomised, double-blind \\
\hline Participants & $\begin{array}{l}1 \text { month to } 13 \text { years; suspected bacterial meningitis with CSF or blood criterion; also patients with sus- } \\
\text { pected bacterial meningitis who were too unstable for lumbar puncture; } 101 \text { participants (gender not } \\
\text { reported; } 50 \text { DXM, } 51 \text { placebo); Canada }\end{array}$ \\
\hline Interventions & DXM $0.6 \mathrm{mg} / \mathrm{kg} / \mathrm{d}, 4 \mathrm{~d}$; after AB \\
\hline
\end{tabular}


King 1994 (Continued) Mortality, hearing loss, neurological sequelae, adverse events (gastrointestinal bleeding, persistent
fever, recurrent fever)

Notes $\quad A B$ - various, mortality $1 \%$

Funding - Physicians' Services Incorporated Foundation (charity)

\section{Risk of bias}

\begin{tabular}{|c|c|c|}
\hline Bias & Authors' judgement & Support for judgement \\
\hline $\begin{array}{l}\text { Random sequence genera- } \\
\text { tion (selection bias) }\end{array}$ & Low risk & Stratified computer-generated randomisation \\
\hline $\begin{array}{l}\text { Allocation concealment } \\
\text { (selection bias) }\end{array}$ & Low risk & Allocation was concealed \\
\hline $\begin{array}{l}\text { Blinding (performance } \\
\text { bias and detection bias) } \\
\text { All outcomes }\end{array}$ & Low risk & The study was double-blind \\
\hline $\begin{array}{l}\text { Incomplete outcome data } \\
\text { (attrition bias) } \\
\text { All outcomes }\end{array}$ & Low risk & Incomplete outcome data addressed \\
\hline $\begin{array}{l}\text { Selective reporting (re- } \\
\text { porting bias) }\end{array}$ & High risk & $\begin{array}{l}\text { No intention-to-treat analysis; more patients were excluded in the dexametha- } \\
\text { sone group because of final diagnosis other than bacterial meningitis }\end{array}$ \\
\hline Other bias & Unclear risk & Insufficient information to determine other bias \\
\hline
\end{tabular}

\section{Lebel 1988a}

\begin{tabular}{ll}
\hline Methods & Randomised, double-blind \\
\hline Participants & $\begin{array}{l}\text { 2 months to } 16 \text { years; suspected or proven bacterial meningitis; } 100 \text { participants (50 male, } 50 \text { female; } \\
51 \text { DXM, } 49 \text { placebo); USA }\end{array}$ \\
\hline Interventions & DXM 0.6 mg/kg/d, $4 \mathrm{~d} ;$ after AB \\
\hline Outcomes & Mortality, hearing loss, neurological sequelae, adverse events (gastrointestinal bleeding, recurrent \\
& fever, arthritis) \\
\hline Notes & AB - ceph, mortality 2\% \\
& Funding - Glaxo and Roche Laboratories (pharmaceutical company) \\
\hline
\end{tabular}

\section{Risk of bias}

\begin{tabular}{lll}
\hline Bias & Authors' judgement & Support for judgement \\
\hline $\begin{array}{l}\text { Random sequence genera- } \\
\text { tion (selection bias) }\end{array}$ & Low risk & Computer-generated randomisation list \\
\hline $\begin{array}{l}\text { Allocation concealment } \\
\text { (selection bias) }\end{array}$ & Low risk & Allocation was concealed \\
\hline
\end{tabular}


Lebel 1988a (Continued)

Blinding (performance Low risk $\quad$ The study was double-blind
bias and detection bias)

All outcomes

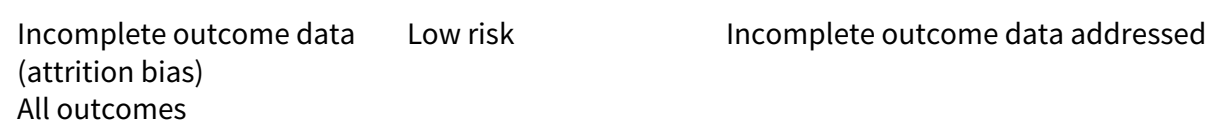

Selective reporting (re- High risk $\quad$ No intention-to-treat analysis
porting bias)

\begin{tabular}{ll}
\hline Other bias $\quad$ Unclear risk $\quad$ Insufficient information to determine other bias \\
\hline
\end{tabular}

\section{Lebel 1988b}

\begin{tabular}{|c|c|c|}
\hline Methods & \multicolumn{2}{|c|}{ Randomised, double-blind } \\
\hline Participants & \multicolumn{2}{|c|}{$\begin{array}{l}2 \text { months to } 16 \text { years; suspected or proven bacterial meningitis; } 100 \text { participants ( } 55 \text { male, } 45 \text { female; } \\
51 \text { DXM, } 49 \text { placebo); USA }\end{array}$} \\
\hline Interventions & \multicolumn{2}{|c|}{ DXM $0.6 \mathrm{mg} / \mathrm{kg} / \mathrm{d}, 4 \mathrm{~d}$; after $\mathrm{AB}$} \\
\hline Outcomes & \multicolumn{2}{|c|}{$\begin{array}{l}\text { Mortality, hearing loss, neurological sequelae, adverse events (gastrointestinal bleeding, recurrent } \\
\text { fever, arthritis) }\end{array}$} \\
\hline Notes & \multicolumn{2}{|l|}{$A B$ - ceph, mortality $2 \%$} \\
\hline & \multicolumn{2}{|c|}{ Funding - Glaxo and Roche Laboratories (pharmaceutical company) } \\
\hline \multicolumn{3}{|l|}{ Risk of bias } \\
\hline Bias & Authors' judgement & Support for judgement \\
\hline $\begin{array}{l}\text { Random sequence genera- } \\
\text { tion (selection bias) }\end{array}$ & Low risk & Computer-generated randomisation list \\
\hline $\begin{array}{l}\text { Allocation concealment } \\
\text { (selection bias) }\end{array}$ & Low risk & Allocation was concealed \\
\hline $\begin{array}{l}\text { Blinding (performance } \\
\text { bias and detection bias) } \\
\text { All outcomes }\end{array}$ & Low risk & The study was double-blind \\
\hline $\begin{array}{l}\text { Incomplete outcome data } \\
\text { (attrition bias) } \\
\text { All outcomes }\end{array}$ & Low risk & Incomplete outcome data addressed \\
\hline $\begin{array}{l}\text { Selective reporting (re- } \\
\text { porting bias) }\end{array}$ & High risk & No intention-to-treat analysis \\
\hline Other bias & Unclear risk & Insufficient information to determine other bias \\
\hline
\end{tabular}


Lebel 1989

\begin{tabular}{ll}
\hline Methods & Randomised, double-blind \\
\hline Participants & 2 months to 16 years; suspected or proven bacterial meningitis; 61 participants (38 male, 23 female; 30 \\
DXM, 31 placebo); USA
\end{tabular}

\begin{tabular}{ll}
\hline Interventions & DXM $0.6 \mathrm{mg} / \mathrm{kg} / \mathrm{d}, 4 \mathrm{~d} ;$ after $\mathrm{AB}$ \\
\hline Outcomes & $\begin{array}{l}\text { Mortality, hearing loss, neurological sequelae, adverse events (gastrointestinal bleeding, recurrent } \\
\text { fever, arthritis) }\end{array}$ \\
\hline Notes & $\mathrm{AB}$ - ceph, mortality $2 \%$ \\
& Funding - in part by Glaxo (pharmaceutical company) \\
\hline
\end{tabular}

\section{Risk of bias}

\begin{tabular}{lll}
\hline Bias & Authors' judgement & Support for judgement \\
\hline $\begin{array}{l}\text { Random sequence genera- } \\
\text { tion (selection bias) }\end{array}$ & Low risk & Computer-generated randomisation list \\
\hline $\begin{array}{l}\text { Allocation concealment } \\
\text { (selection bias) }\end{array}$ & Low risk & Allocation was concealed \\
\hline $\begin{array}{l}\text { Blinding (performance } \\
\text { bias and detection bias) } \\
\text { All outcomes }\end{array}$ & Low risk & The study was double-blind \\
\hline $\begin{array}{l}\text { Incomplete outcome data } \\
\text { (attrition bias) } \\
\text { All outcomes }\end{array}$ & Low risk & Incomplete outcome data addressed \\
\hline $\begin{array}{l}\text { Selective reporting (re- } \\
\text { porting bias) }\end{array}$ & High risk & No intention-to-treat analysis \\
\hline $\begin{array}{l}\text { Other bias } \\
\text { High risk }\end{array}$ & $\begin{array}{l}\text { Unevenly distributed number of antimicrobial resistance rates between treat- } \\
\text { ment groups (control group worse) }\end{array}$ \\
\hline
\end{tabular}

\section{Mathur 2013}

\begin{tabular}{ll}
\hline Methods & Randomised, unblinded \\
\hline Participants & $\begin{array}{l}\text { Neonates (not defined); suspected meningitis with CSF criteria; } 80 \text { participants (51 male, } 39 \text { female; } 40 \\
\text { DXM, } 40 \text { placebo); India }\end{array}$ \\
\hline Interventions & DXM $0.6 \mathrm{mg} / \mathrm{kg} / \mathrm{d}, 2$ days, with AB \\
\hline Outcomes & Mortality, hearing loss, CSF parameters of inflammation at $24 \mathrm{~h}$, disease severity \\
\hline Notes & AB - ceph/amikacine + meropenem in severe cases, mortality $26 \%$ \\
& Funding - none reported \\
\hline
\end{tabular}

\section{Risk of bias}


Mathur 2013 (Continued)

\begin{tabular}{|c|c|c|}
\hline Bias & Authors' judgement & Support for judgement \\
\hline $\begin{array}{l}\text { Random sequence genera- } \\
\text { tion (selection bias) }\end{array}$ & Low risk & Web-based randomisation \\
\hline $\begin{array}{l}\text { Allocation concealment } \\
\text { (selection bias) }\end{array}$ & Low risk & Allocation was concealed \\
\hline $\begin{array}{l}\text { Blinding (performance } \\
\text { bias and detection bias) } \\
\text { All outcomes }\end{array}$ & High risk & No blinding \\
\hline $\begin{array}{l}\text { Incomplete outcome data } \\
\text { (attrition bias) } \\
\text { All outcomes }\end{array}$ & Low risk & Data complete, no patients lost to follow-up or discontinued treatment \\
\hline $\begin{array}{l}\text { Selective reporting (re- } \\
\text { porting bias) }\end{array}$ & Low risk & Data complete, no patients lost to follow-up or discontinued treatment \\
\hline Other bias & High risk & $\begin{array}{l}\text { Differences in causative bacteria and culture-positive cases between treat- } \\
\text { ment groups }\end{array}$ \\
\hline
\end{tabular}

Molyneux 2002

\begin{tabular}{ll}
\hline Methods & Randomised, double-blind \\
\hline Participants & $\begin{array}{l}\text { 2 months to } 13 \text { years; suspected bacterial meningitis with CSF criteria; } 598 \text { participants (337 male, } 261 \\
\text { female; } 307 \mathrm{DXM}, 295 \text { placebo); Malawi }\end{array}$ \\
\hline Interventions & DXM $0.8 \mathrm{mg} / \mathrm{kg} / \mathrm{d}, 2 \mathrm{~d}$; before or with AB \\
\hline Outcomes & Mortality, hearing loss, neurological sequelae \\
\hline Notes & AB - pen/chlor, mortality 31\% \\
& Funding - Child and Adolescent Health and Development Division of WHO \\
\hline
\end{tabular}

\section{Risk of bias}

\begin{tabular}{lll}
\hline Bias & Authors' judgement & Support for judgement \\
\hline $\begin{array}{l}\text { Random sequence genera- } \\
\text { tion (selection bias) }\end{array}$ & Low risk & Block randomisation \\
\hline $\begin{array}{l}\text { Allocation concealment } \\
\text { (selection bias) }\end{array}$ & Low risk & Allocation was concealed \\
\hline $\begin{array}{l}\text { Blinding (performance } \\
\text { bias and detection bias) } \\
\text { All outcomes }\end{array}$ & Low risk & The study was double-blind \\
\hline $\begin{array}{l}\text { Incomplete outcome data } \\
\text { (attrition bias) } \\
\begin{array}{l}\text { All outcomes } \\
\hline\end{array}\end{array}$ & Low risk & Incomplete outcome data addressed \\
\hline
\end{tabular}


Molyneux 2002 (Continued)

Selective reporting (re- Low risk Intention-to-treat analysis
porting bias)

Other bias Low risk No indication of other bias

\section{Nguyen 2007}

\begin{tabular}{ll}
\hline Methods & Randomised, double-blind \\
\hline Participants & $\begin{array}{l}\text { Older than } 14 \text { years; culture-proven bacterial meningitis or suspected bacterial meningitis with CSF cri- } \\
\text { teria; } 435 \text { participants ( } 317 \text { male, } 118 \text { female; } 217 \text { DXM, } 218 \text { placebo); Vietnam }\end{array}$ \\
\hline Interventions & DXM $0.8 \mathrm{mg} / \mathrm{kg} / \mathrm{d}, 4 \mathrm{~d}$; before or with AB \\
\hline Outcomes & $\begin{array}{l}\text { Mortality, hearing loss, neurological sequelae, adverse events (herpes zoster infection, gastrointestinal } \\
\text { bleeding) }\end{array}$ \\
\hline Notes & AB - various; mortality $11 \%$ \\
& Funding - Wellcome Trust (charity)
\end{tabular}

\section{Risk of bias}

\begin{tabular}{|c|c|c|}
\hline Bias & Authors' judgement & Support for judgement \\
\hline $\begin{array}{l}\text { Random sequence genera- } \\
\text { tion (selection bias) }\end{array}$ & Low risk & Computer-generated randomisation list, block size 100 \\
\hline $\begin{array}{l}\text { Allocation concealment } \\
\text { (selection bias) }\end{array}$ & Low risk & Allocation was concealed \\
\hline $\begin{array}{l}\text { Blinding (performance } \\
\text { bias and detection bias) } \\
\text { All outcomes }\end{array}$ & Low risk & The study was double-blind \\
\hline $\begin{array}{l}\text { Incomplete outcome data } \\
\text { (attrition bias) } \\
\text { All outcomes }\end{array}$ & Low risk & Incomplete outcome data addressed \\
\hline $\begin{array}{l}\text { Selective reporting (re- } \\
\text { porting bias) }\end{array}$ & Low risk & Intention-to-treat analysis \\
\hline Other bias & Low risk & No indication of other bias \\
\hline
\end{tabular}

\section{Odio 1991}

\begin{tabular}{ll}
\hline Methods & Randomised, double-blind \\
\hline Participants & $\begin{array}{l}\text { 6 weeks to } 16 \text { years; culture-proven bacterial meningitis or suspected bacterial meningitis with CSF in- } \\
\text { flammation; } 101 \text { participants ( } 59 \text { male, } 42 \text { female; } 52 \text { DXM, } 49 \text { placebo); USA }\end{array}$ \\
\hline Interventions & DXM $0.6 \mathrm{mg} / \mathrm{kg} / \mathrm{d}, 4 \mathrm{~d}$; before or with AB \\
\hline
\end{tabular}


Odio 1991 (Continued)

Outcomes Mortality, hearing loss, neurological sequelae, adverse events (gastrointestinal bleeding, persistent fever, recurrent fever, arthritis)

Notes

$A B$ - ceph, mortality - $2 \%$

Funding - Hoechst-Roussel Pharmaceuticals (pharmaceutical company)

\section{Risk of bias}

\begin{tabular}{|c|c|c|}
\hline Bias & Authors' judgement & Support for judgement \\
\hline $\begin{array}{l}\text { Random sequence genera- } \\
\text { tion (selection bias) }\end{array}$ & Low risk & Computer-generated randomisation list \\
\hline $\begin{array}{l}\text { Allocation concealment } \\
\text { (selection bias) }\end{array}$ & Low risk & Allocation was concealed \\
\hline $\begin{array}{l}\text { Blinding (performance } \\
\text { bias and detection bias) } \\
\text { All outcomes }\end{array}$ & Low risk & The study was double-blind \\
\hline $\begin{array}{l}\text { Incomplete outcome data } \\
\text { (attrition bias) } \\
\text { All outcomes }\end{array}$ & Low risk & Incomplete outcome data addressed \\
\hline $\begin{array}{l}\text { Selective reporting (re- } \\
\text { porting bias) }\end{array}$ & High risk & No intention-to-treat analysis \\
\hline Other bias & Unclear risk & Insufficient information to determine other bias \\
\hline
\end{tabular}

\section{Peltola 2007}

\begin{tabular}{ll}
\hline Methods & Randomised, double-blind \\
\hline Participants & $\begin{array}{l}2 \text { months to } 16 \text { years; proven or suspected bacterial meningitis with CSF criteria; } 329 \text { participants } \\
\text { (191 male, } 138 \text { female; } 166 \mathrm{DXM}, 163 \text { placebo); Argentina, Ecuador,Venezuela, Dominican Republic, } \\
\text { Paraguay, Brazil }\end{array}$ \\
\hline Interventions & DXM 0.6 $\mathrm{mg} / \mathrm{kg} / \mathrm{d}, 4 \mathrm{~d}$; before or with AB \\
\hline Outcomes & Mortality, neurological sequelae, hearing loss, adverse events (gastrointestinal bleeding, recurrent \\
\hline fever $)$ & AB - ceph, mortality 15\% \\
Other - trial also evaluated adjunctive glycerol and combined adjunctive glycerol and DXM therapy \\
Funding - Alfred Kordelin, Paivikki and Sakari Sohlberg, and Sigfrid Juselius Funds (charities). Glax- \\
OSmithKline, Farmacia Ahumada, Laboratorio de Chile (pharmaceutical companies)
\end{tabular}

\section{Risk of bias}

\begin{tabular}{lll}
\hline Bias & Authors' judgement & Support for judgement \\
\hline $\begin{array}{l}\text { Random sequence genera- } \\
\text { tion (selection bias) }\end{array}$ & Low risk & Randomisation list, block size 24 \\
\hline \hline
\end{tabular}


Peltola 2007 (Continued)

$\begin{array}{ll}\begin{array}{l}\text { Allocation concealment } \\ \text { (selection bias) }\end{array} & \begin{array}{l}\text { Partial allocation concealment: } 2 \text { hospitals did not allow double placebo treat- } \\ \text { ment }\end{array}\end{array}$

Blinding (performance Low risk The study was double-blind

bias and detection bias)

All outcomes

Incomplete outcome data Low risk Incomplete outcome data addressed
(attrition bias)

(attrition bias)

All outcomes

\begin{tabular}{lll}
$\begin{array}{l}\text { Selective reporting (re- } \\
\text { porting bias) }\end{array}$ & Low risk & Intention-to-treat analysis \\
\hline Other bias & Unclear risk & Unevenly distributed antibiotic pretreatment between randomisation arms
\end{tabular}

\section{Qazi 1996}

\begin{tabular}{ll}
\hline Methods & Randomised, double-blind \\
\hline Participants & $\begin{array}{l}\text { 2 months to } 12 \text { years; suspected bacterial meningitis with CSF criteria; } 89 \text { participants (54 male, } 35 \text { fe- } \\
\text { male; } 48 \text { DXM, } 41 \text { placebo); Pakistan }\end{array}$ \\
\hline Interventions & DXM $0.6 \mathrm{mg} / \mathrm{kg} / \mathrm{d}, 4 \mathrm{~d}$; before or with AB \\
\hline Outcomes & Mortality, hearing loss, neurological sequelae, adverse events (gastrointestinal bleeding) \\
\hline Notes & AB - ampi/chlor, mortality $19 \%$ \\
& $\begin{array}{l}\text { Funding - Department of Paediatrics and Child Health, Kurume University, Kurume, Japan and the } \\
\text { Japanese International Cooperation Agency (government funding body) }\end{array}$
\end{tabular}

\section{Risk of bias}

\begin{tabular}{|c|c|c|}
\hline Bias & Authors' judgement & Support for judgement \\
\hline $\begin{array}{l}\text { Random sequence genera- } \\
\text { tion (selection bias) }\end{array}$ & Low risk & Computer-generated randomisation list \\
\hline $\begin{array}{l}\text { Allocation concealment } \\
\text { (selection bias) }\end{array}$ & Low risk & Allocation was concealed \\
\hline $\begin{array}{l}\text { Blinding (performance } \\
\text { bias and detection bias) } \\
\text { All outcomes }\end{array}$ & Low risk & The study was double-blind \\
\hline $\begin{array}{l}\text { Incomplete outcome data } \\
\text { (attrition bias) } \\
\text { All outcomes }\end{array}$ & Low risk & Incomplete outcome data addressed \\
\hline $\begin{array}{l}\text { Selective reporting (re- } \\
\text { porting bias) }\end{array}$ & High risk & No intention-to-treat analysis \\
\hline Other bias & High risk & $\begin{array}{l}\text { High rate of culture-negative patients. High mortality but low rate of hearing } \\
\text { loss. More changes in antibiotic therapy in control population }\end{array}$ \\
\hline
\end{tabular}


Sankar 2007

\begin{tabular}{ll}
\hline Methods & Randomised, double-blind \\
\hline Participants & $\begin{array}{l}\text { 2 months to } 12 \text { years; suspected bacterial meningitis with CSF criteria; } 25 \text { participants (22 male, } 3 \text { fe- } \\
\text { male; } 12 \text { DXM, } 13 \text { placebo); India }\end{array}$ \\
\hline Interventions & DXM $0.9 \mathrm{mg} / \mathrm{kg}, 2 \mathrm{~d}$; timing unclear \\
\hline Outcomes & Mortality, neurological sequelae, adverse events (gastrointestinal bleeding) \\
\hline Notes & AB - ceph, mortality 4\% \\
& Other - trial also evaluated adjunctive glycerol and combined adjunctive glycerol and DXM therapy \\
& Funding - none reported \\
\hline
\end{tabular}

\section{Risk of bias}

\begin{tabular}{|c|c|c|}
\hline Bias & Authors' judgement & Support for judgement \\
\hline $\begin{array}{l}\text { Random sequence genera- } \\
\text { tion (selection bias) }\end{array}$ & Low risk & Random number table \\
\hline $\begin{array}{l}\text { Allocation concealment } \\
\text { (selection bias) }\end{array}$ & Low risk & Allocation was concealed \\
\hline $\begin{array}{l}\text { Blinding (performance } \\
\text { bias and detection bias) } \\
\text { All outcomes }\end{array}$ & Low risk & The study was double-blind \\
\hline $\begin{array}{l}\text { Incomplete outcome data } \\
\text { (attrition bias) } \\
\text { All outcomes }\end{array}$ & Low risk & Incomplete outcome data addressed \\
\hline $\begin{array}{l}\text { Selective reporting (re- } \\
\text { porting bias) }\end{array}$ & Low risk & Intention-to-treat analysis \\
\hline Other bias & Unclear risk & $\begin{array}{l}\text { Only } 1 \text { patient with positive culture in DXM randomisation arm. Unevenly dis- } \\
\text { tributed numbers in randomisation arms. Large differences in baseline charac- } \\
\text { teristics between randomisation arms }\end{array}$ \\
\hline
\end{tabular}

Scarborough 2007

\begin{tabular}{ll}
\hline Methods & Randomised, double-blind \\
\hline Participants & $\begin{array}{l}\text { Older than 15 years; suspected bacterial meningitis with CSF criteria; } 465 \text { participants (230 male, } 236 \\
\text { female; 233 DXM, 232placebo); Malawi }\end{array}$ \\
\hline Interventions & DXM $32 \mathrm{mg} /$ day, $4 \mathrm{~d}$; before or with AB \\
\hline Outcomes & $\begin{array}{l}\text { Mortality, neurological sequelae, hearing loss, adverse events (herpes zoster infection, gastrointestinal } \\
\text { bleeding, recurrent fever) }\end{array}$ \\
\hline Notes & AB - ceph, mortality 54\% \\
\hline
\end{tabular}


Scarborough 2007 (Continued)

Funding - Meningitis Research Foundation (charity), Emcure Pharmaceuticals and Cipla (pharmaceutical companies)

\section{Risk of bias}

\begin{tabular}{|c|c|c|}
\hline Bias & Authors' judgement & Support for judgement \\
\hline $\begin{array}{l}\text { Random sequence genera- } \\
\text { tion (selection bias) }\end{array}$ & Low risk & Computer-generated randomisation list, block size 8 \\
\hline $\begin{array}{l}\text { Allocation concealment } \\
\text { (selection bias) }\end{array}$ & Low risk & Allocation was concealed \\
\hline $\begin{array}{l}\text { Blinding (performance } \\
\text { bias and detection bias) } \\
\text { All outcomes }\end{array}$ & Low risk & The study was double-blind \\
\hline $\begin{array}{l}\text { Incomplete outcome data } \\
\text { (attrition bias) } \\
\text { All outcomes }\end{array}$ & Low risk & Incomplete outcome data addressed \\
\hline $\begin{array}{l}\text { Selective reporting (re- } \\
\text { porting bias) }\end{array}$ & Low risk & Intention-to-treat analysis \\
\hline Other bias & Low risk & No indication of other bias \\
\hline
\end{tabular}

\section{Schaad 1993}

\begin{tabular}{ll}
\hline Methods & Randomised, double-blind \\
\hline Participants & $\begin{array}{l}\text { 3 months to } 16 \text { years; suspected or proven bacterial; } 115 \text { participants (69 male, } 46 \text { female; } 60 \text { DXM, } 55 \\
\text { placebo); Switzerland }\end{array}$ \\
\hline Interventions & DXM 0.8 mg/kg/d, 2 d; before or with AB \\
\hline Outcomes & $\begin{array}{l}\text { Mortality, hearing loss, neurological sequelae, adverse events (gastrointestinal bleeding, recurrent } \\
\text { fever, persistent fever, arthritis) }\end{array}$ \\
\hline Notes & AB - ceph, mortality 0\% \\
& Funding - Merck Sharp \& Dohme-Chibret Ltd (pharmaceutical company) \\
\hline
\end{tabular}

\section{Risk of bias}

\begin{tabular}{lll}
\hline Bias & Authors' judgement & Support for judgement \\
\hline $\begin{array}{l}\text { Random sequence genera- } \\
\text { tion (selection bias) }\end{array}$ & Low risk & Computer-generated randomisation list \\
\hline $\begin{array}{l}\text { Allocation concealment } \\
\text { (selection bias) }\end{array}$ & Low risk & Allocation was concealed \\
\hline $\begin{array}{l}\text { Blinding (performance } \\
\text { bias and detection bias) } \\
\text { All outcomes }\end{array}$ & Low risk & The study was double-blind \\
\hline
\end{tabular}


Schaad 1993 (Continued)
Incomplete outcome data
High risk
Incomplete outcome data not addressed
(attrition bias)

All outcomes

Selective reporting (re- High risk $\quad$ No intention-to-treat analysis
porting bias)

\begin{tabular}{ll}
\hline Other bias $\quad$ Unclear risk $\quad$ Insufficient information to determine other bias \\
\hline
\end{tabular}

Thomas 1999

\begin{tabular}{ll}
\hline Methods & Randomised, double-blind \\
\hline Participants & $\begin{array}{l}17 \text { to } 99 \text { years; suspected bacterial meningitis with CSF criteria; } 60 \text { participants (34 male, } 26 \text { female; } 31 \\
\text { DXM, } 29 \text { placebo); France and Switzerland }\end{array}$ \\
\hline
\end{tabular}

\begin{tabular}{ll}
\hline Interventions & DXM $40 \mathrm{mg} / \mathrm{d}, 3 \mathrm{~d}$; after $\mathrm{AB}$ \\
\hline Outcomes & Mortality, neurological sequelae, adverse events (herpes zoster infection, gastrointestinal bleeding) \\
\hline Notes & $\mathrm{AB}$ - amox, mortality $13 \%$ \\
& $\begin{array}{l}\text { Funding - Institut National de la Sante et de la Recherche Medicale (government funding body), the } \\
\text { Beecham Institute and the Merck Sharp \& Dohme Chibret laboratory (pharmaceutical company) }\end{array}$ \\
\hline
\end{tabular}

\section{Risk of bias}

\begin{tabular}{lll}
\hline Bias & Authors' judgement & Support for judgement \\
\hline $\begin{array}{l}\text { Random sequence genera- } \\
\text { tion (selection bias) }\end{array}$ & Low risk & Stratified, equilibrated randomisation list \\
\hline $\begin{array}{l}\text { Allocation concealment } \\
\text { (selection bias) }\end{array}$ & Low risk & Allocation was concealed \\
\hline $\begin{array}{l}\text { Blinding (performance } \\
\text { bias and detection bias) } \\
\text { All outcomes }\end{array}$ & Low risk & The study was double-blind \\
\hline $\begin{array}{l}\text { Incomplete outcome data } \\
\text { (attrition bias) } \\
\begin{array}{l}\text { All outcomes } \\
\text { Selective reporting (re- }\end{array}\end{array}$ & High risk & High risk \\
\hline porting bias) & Incomplete outcome data not addressed \\
\hline $\begin{array}{l}\text { Other bias } \\
\text { High risk }\end{array}$ & No intention-to-treat analysis \\
\hline
\end{tabular}

Wald 1995

Methods Randomised, double-blind


Wald 1995 (Continued) Participants 2 months to 12 years; suspected bacterial meningitis with CSF criteria; 143 participants (79 male, 64 fe-
male; 69 DXM, 74 placebo); USA

Interventions DXM $0.6 \mathrm{mg} / \mathrm{kg} / \mathrm{d}, 4 \mathrm{~d}$; after $\mathrm{AB}$

Outcomes Mortality, hearing loss, neurological sequelae, adverse events (gastrointestinal bleeding, recurrent fever, arthritis)

\begin{tabular}{ll}
\hline Notes & AB - cephalosporin, mortality - $1 \%$ \\
Funding - Hoffman-LaRoche (pharmaceutical company) \\
\hline
\end{tabular}

\section{Risk of bias}

\begin{tabular}{|c|c|c|}
\hline Bias & Authors' judgement & Support for judgement \\
\hline $\begin{array}{l}\text { Random sequence genera- } \\
\text { tion (selection bias) }\end{array}$ & Low risk & Computer-generated randomisation list, block size 10 \\
\hline $\begin{array}{l}\text { Allocation concealment } \\
\text { (selection bias) }\end{array}$ & Low risk & Allocation was concealed \\
\hline $\begin{array}{l}\text { Blinding (performance } \\
\text { bias and detection bias) } \\
\text { All outcomes }\end{array}$ & Low risk & The study was double-blind \\
\hline $\begin{array}{l}\text { Incomplete outcome data } \\
\text { (attrition bias) } \\
\text { All outcomes }\end{array}$ & Low risk & Incomplete outcome data addressed \\
\hline $\begin{array}{l}\text { Selective reporting (re- } \\
\text { porting bias) }\end{array}$ & High risk & No intention-to-treat analysis \\
\hline Other bias & Unclear risk & $\begin{array}{l}\text { Distribution of resistant bacterial strains ( } 23 \text { out of } 143 \text { strains) between ran- } \\
\text { domisation arms is not reported }\end{array}$ \\
\hline
\end{tabular}

$A B$ : antibiotics

Amox: amoxicillin

Ampi: ampicillin

Ceph: cephalosporin

Chlor: chloramphenicol

CSF: cerebrospinal fluid

d: days

DXM: dexamethasone

$\mathrm{m}^{2}$ : square metre

Pen: penicillin

Sulf: sulfadiazine

Characteristics of excluded studies [ordered by study ID]

\begin{tabular}{ll}
\hline Study & Reason for exclusion \\
\hline Ayaz 2008 & Inadequate sequence generation \\
\hline Baldy 1986 & Inadequate sequence generation
\end{tabular}




\begin{tabular}{|c|c|}
\hline Study & Reason for exclusion \\
\hline Daoud 1999 & Inadequate sequence generation \\
\hline Farina 1995 & Not enough data for inclusion (abstract only) \\
\hline Gijwani 2002 & Inadequate sequence generation \\
\hline Gupta 1996 & Inadequate sequence generation \\
\hline Jensen 1969 & Inadequate sequence generation \\
\hline Lepper 1959 & Inadequate sequence generation \\
\hline Marguet 1993 & No randomisation \\
\hline Ozen 2006 & No randomisation \\
\hline Passos 1979 & Inadequate sequence generation \\
\hline Peltola 2004 & Not enough data for inclusion \\
\hline Shembesh 1997 & Inadequate sequence generation \\
\hline Singhi 2008 & Data previously published (Sankar 2007) \\
\hline Syrogiannopoulos 1994 & No placebo group, compared 2-day 4-day regimen of dexamethasone \\
\hline Tolaj 2010 & No randomisation \\
\hline
\end{tabular}

\section{DATA AND ANALYSES}

\section{Comparison 1. All patients}

\begin{tabular}{llllll}
\hline Outcome or subgroup title & $\begin{array}{l}\text { No. of } \\
\text { studies }\end{array}$ & $\begin{array}{l}\text { No. of } \\
\text { partici- } \\
\text { pants }\end{array}$ & Statistical method & Effect size \\
\hline 1 Mortality & 25 & 4121 & Risk Ratio (M-H, Fixed, 95\% Cl) & $0.90[0.80,1.01]$ \\
\hline 2 Severe hearing loss & 17 & 2437 & Risk Ratio (M-H, Fixed, 95\% Cl) & $0.67[0.51,0.88]$ \\
\hline 3 Any hearing loss & 20 & 2785 & Risk Ratio (M-H, Fixed, 95\% Cl) & $0.74[0.63,0.87]$ \\
\hline 4 Short-term neurological sequelae & 13 & 1756 & Risk Ratio (M-H, Fixed, 95\% Cl) & $0.83[0.69,1.00]$ \\
\hline 5 Long-term neurological sequelae & 13 & 1706 & Risk Ratio (M-H, Fixed, 95\% Cl) & $0.90[0.74,1.10]$ \\
\hline 6 Adverse events & 20 & & Risk Ratio (M-H, Fixed, 95\% Cl) & Subtotals only \\
\hline 6.1 Gastrointestinal bleeding & 16 & 2560 & Risk Ratio (M-H, Fixed, 95\% Cl) & $1.45[0.86,2.45]$ \\
\hline 6.2 Herpes zoster infection & 6 & 1432 & Risk Ratio (M-H, Fixed, 95\% Cl) & $1.09[0.86,1.37]$ \\
\hline
\end{tabular}




\begin{tabular}{lllll}
\hline Outcome or subgroup title & $\begin{array}{l}\text { No. of } \\
\text { studies }\end{array}$ & $\begin{array}{l}\text { No. of } \\
\text { partici- } \\
\text { pants }\end{array}$ & Statistical method & Effect size \\
\hline 6.3 Persistent fever & 3 & 316 & Risk Ratio (M-H, Fixed, 95\% Cl) & $0.29[0.12,0.70]$ \\
\hline 6.4 Recurrent fever & 12 & 1723 & Risk Ratio (M-H, Fixed, 95\% Cl) & $1.27[1.09,1.47]$ \\
\hline 6.5 Fungal infection & 1 & 301 & Risk Ratio (M-H, Fixed, 95\% Cl) & $1.83[0.56,5.96]$ \\
\hline 6.6 Arthritis & 6 & 618 & Risk Ratio (M-H, Fixed, 95\% Cl) & $0.64[0.27,1.53]$ \\
\hline
\end{tabular}

Analysis 1.1. Comparison 1 All patients, Outcome 1 Mortality.

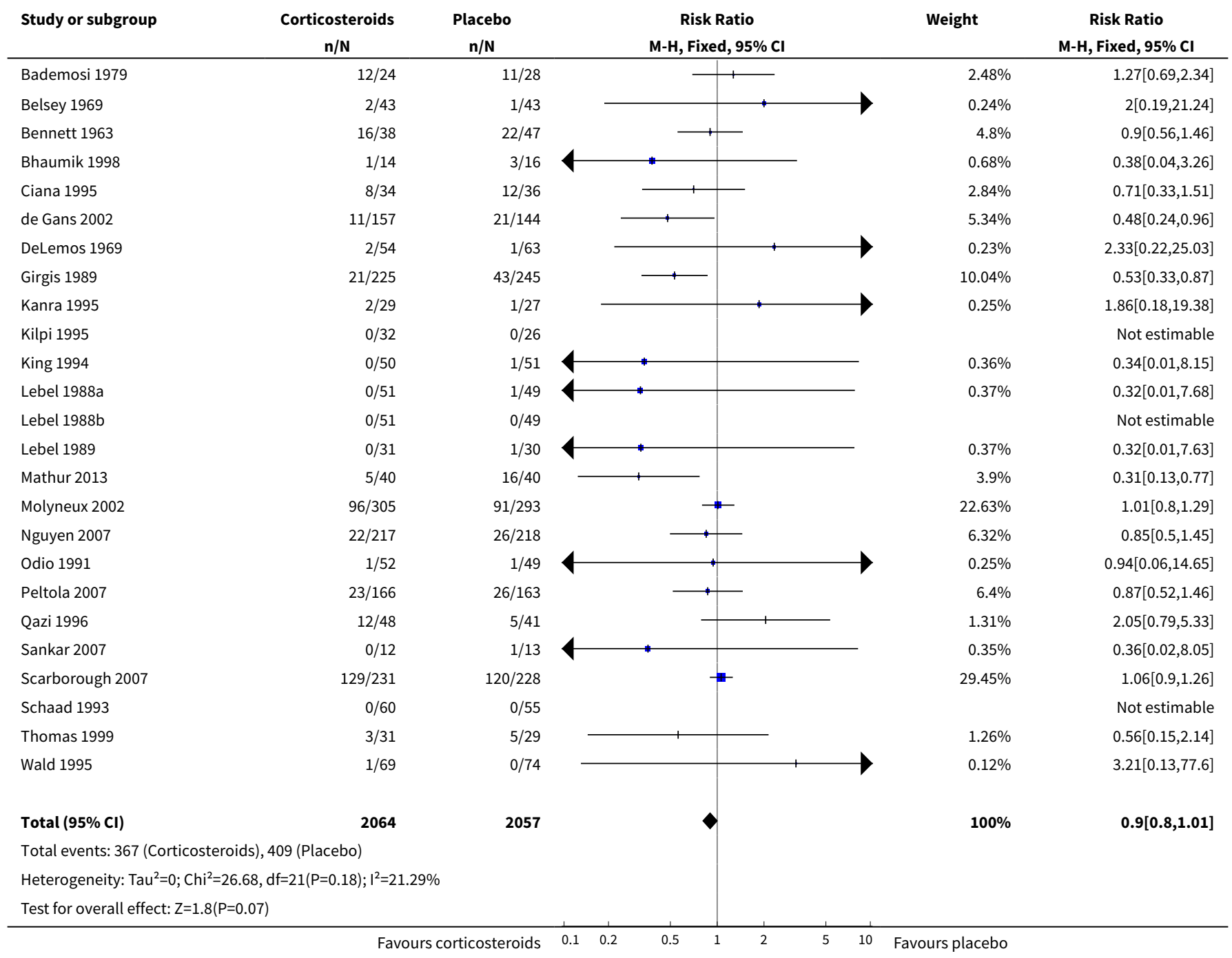


Analysis 1.2. Comparison 1 All patients, Outcome 2 Severe hearing loss.

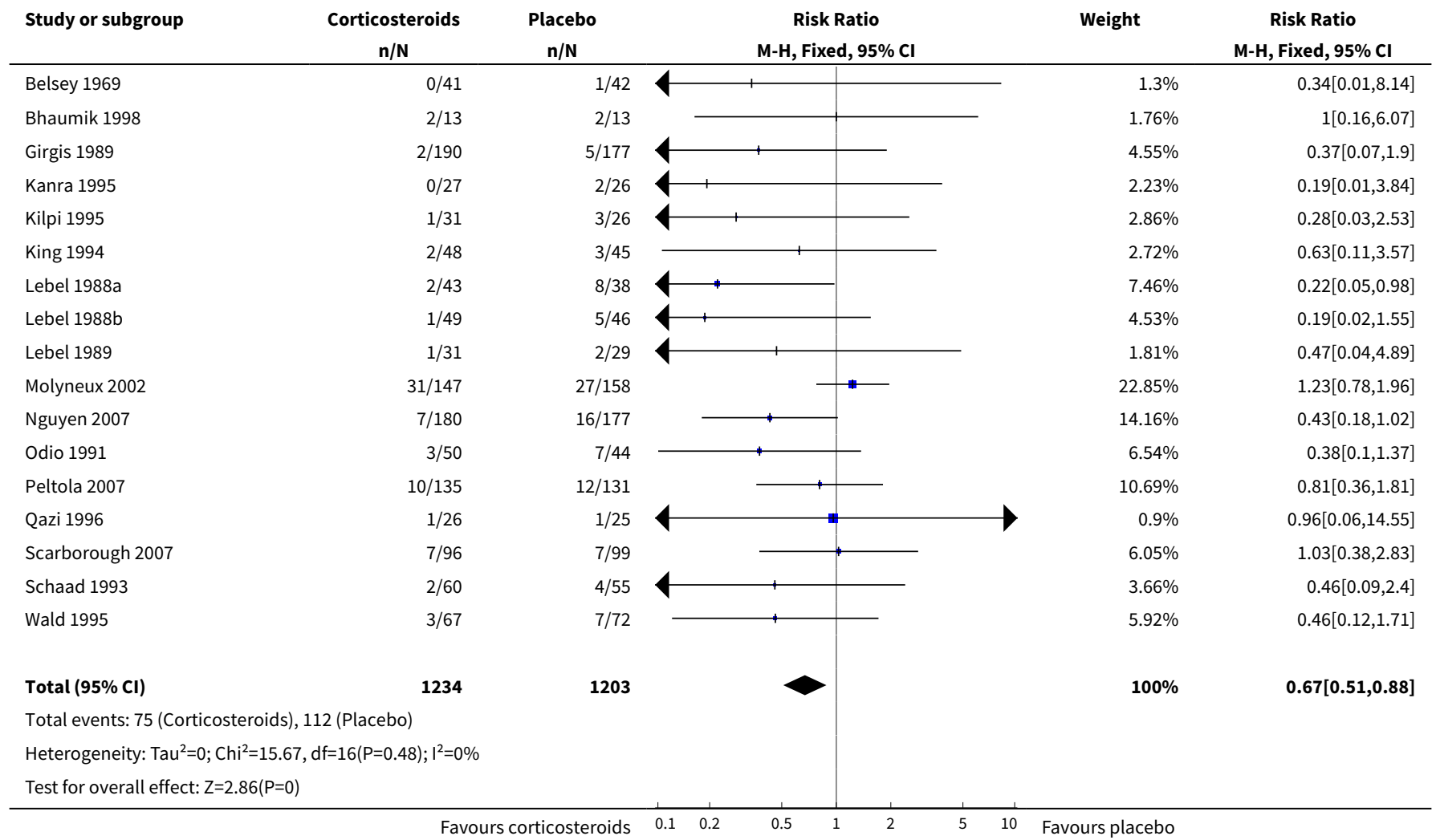

Analysis 1.3. Comparison 1 All patients, Outcome 3 Any hearing loss.

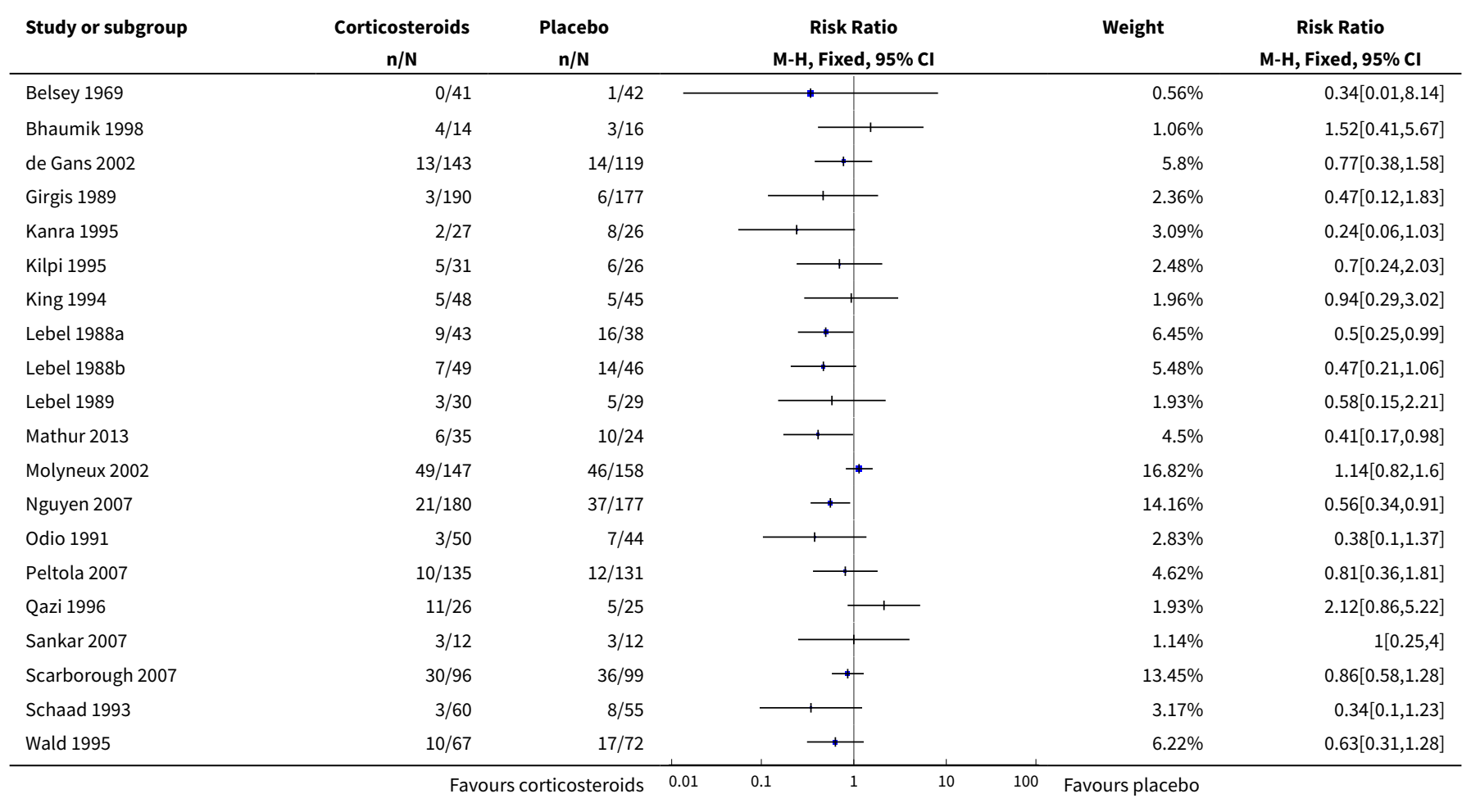




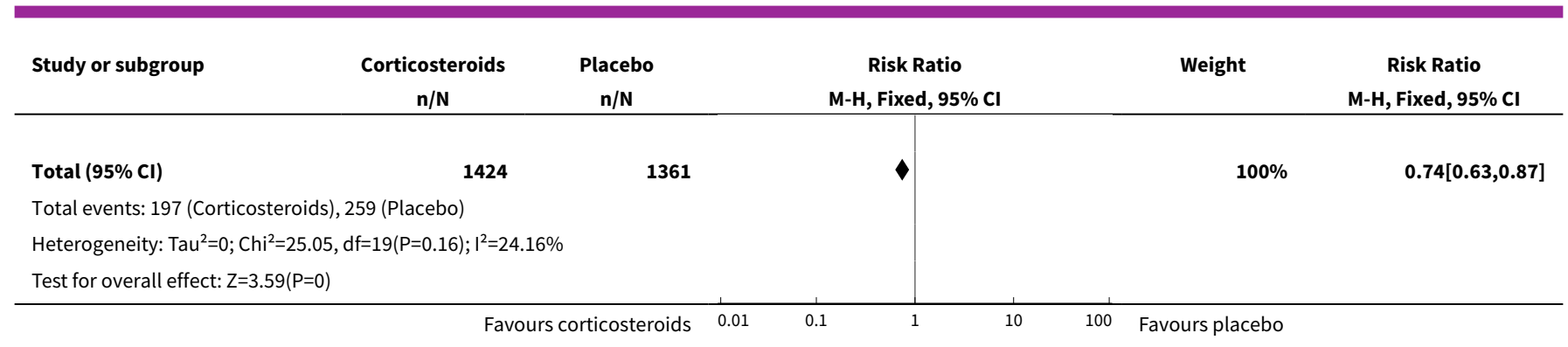

Analysis 1.4. Comparison 1 All patients, Outcome 4 Short-term neurological sequelae.

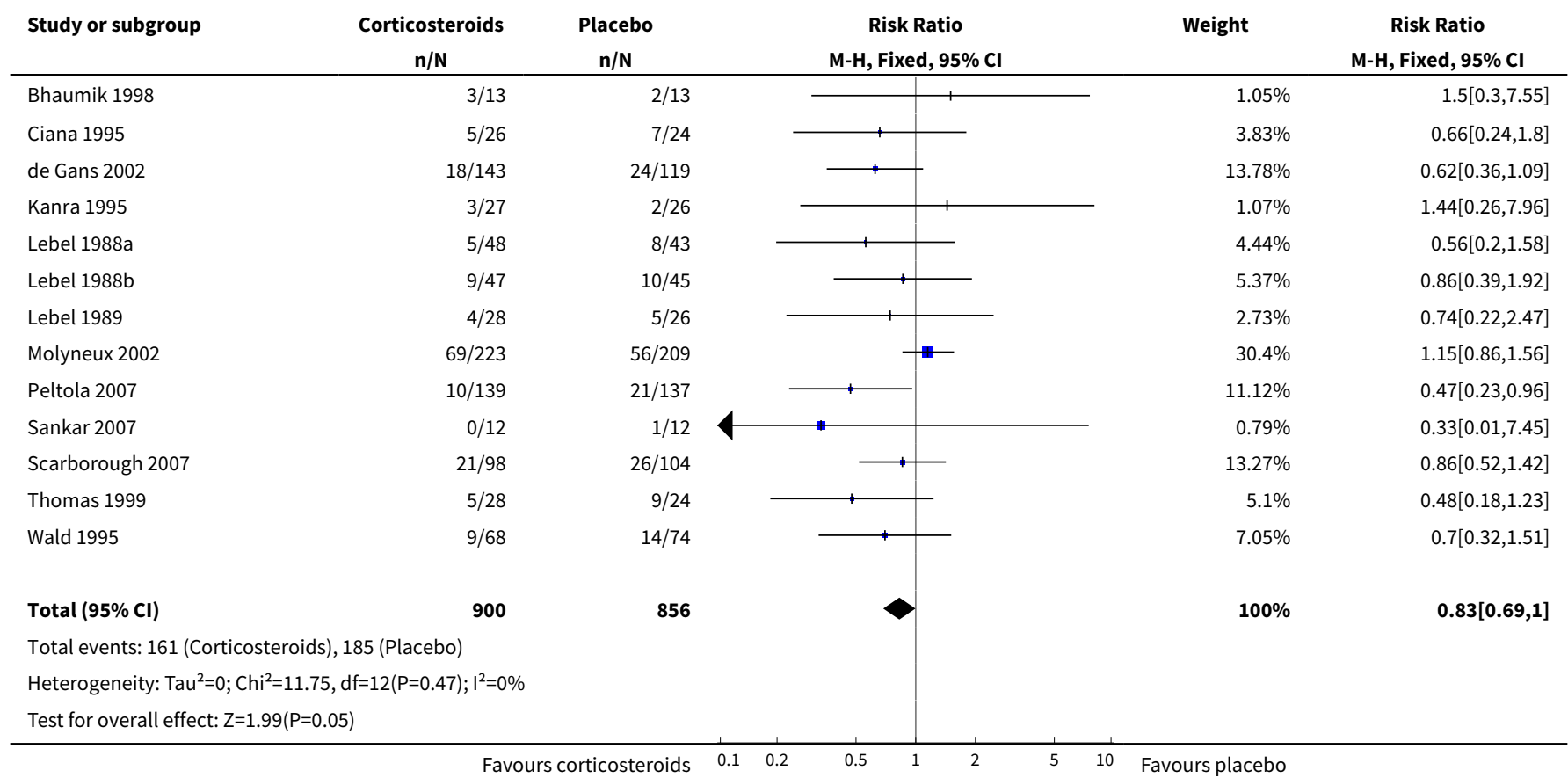

Analysis 1.5. Comparison 1 All patients, Outcome 5 Long-term neurological sequelae.

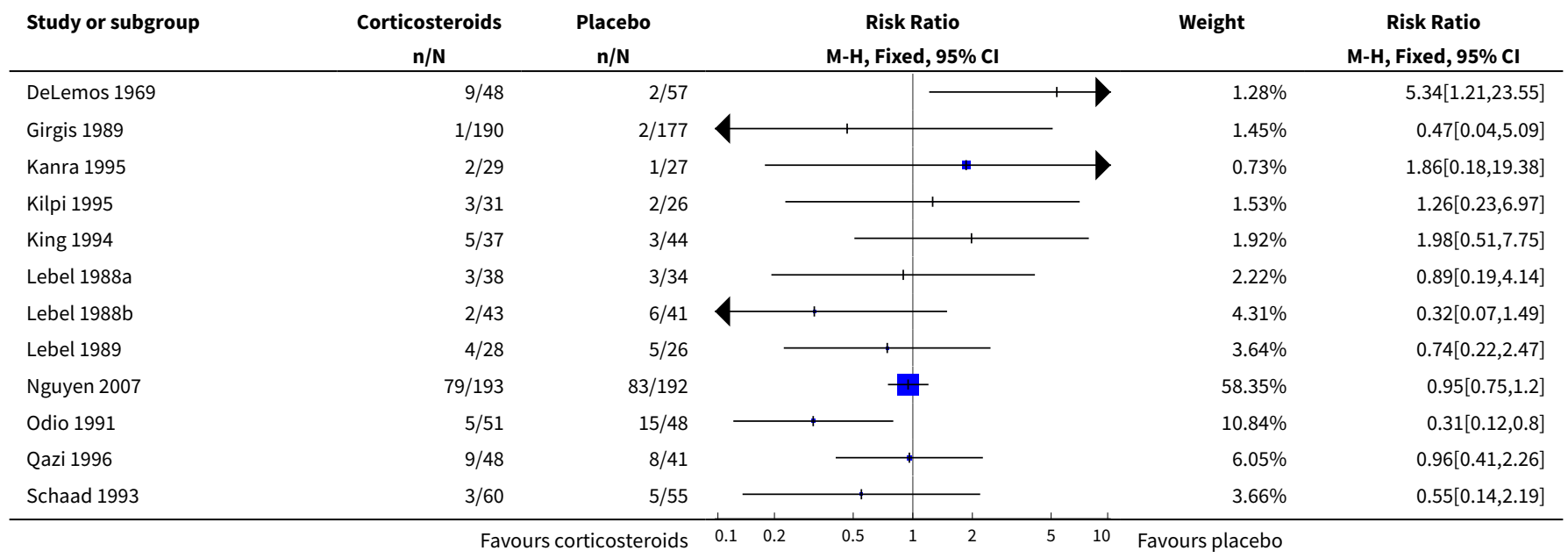




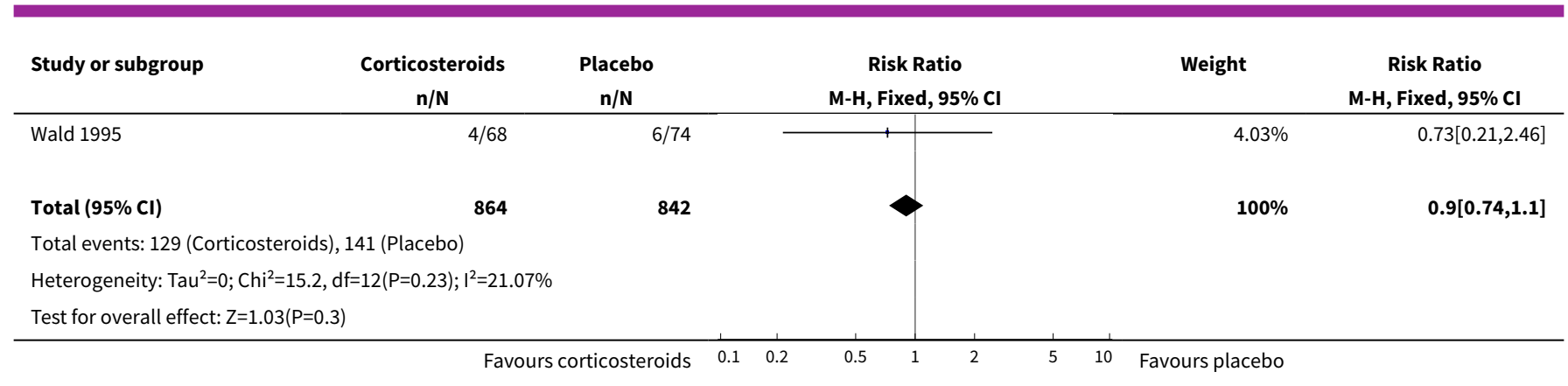

Analysis 1.6. Comparison 1 All patients, Outcome 6 Adverse events.

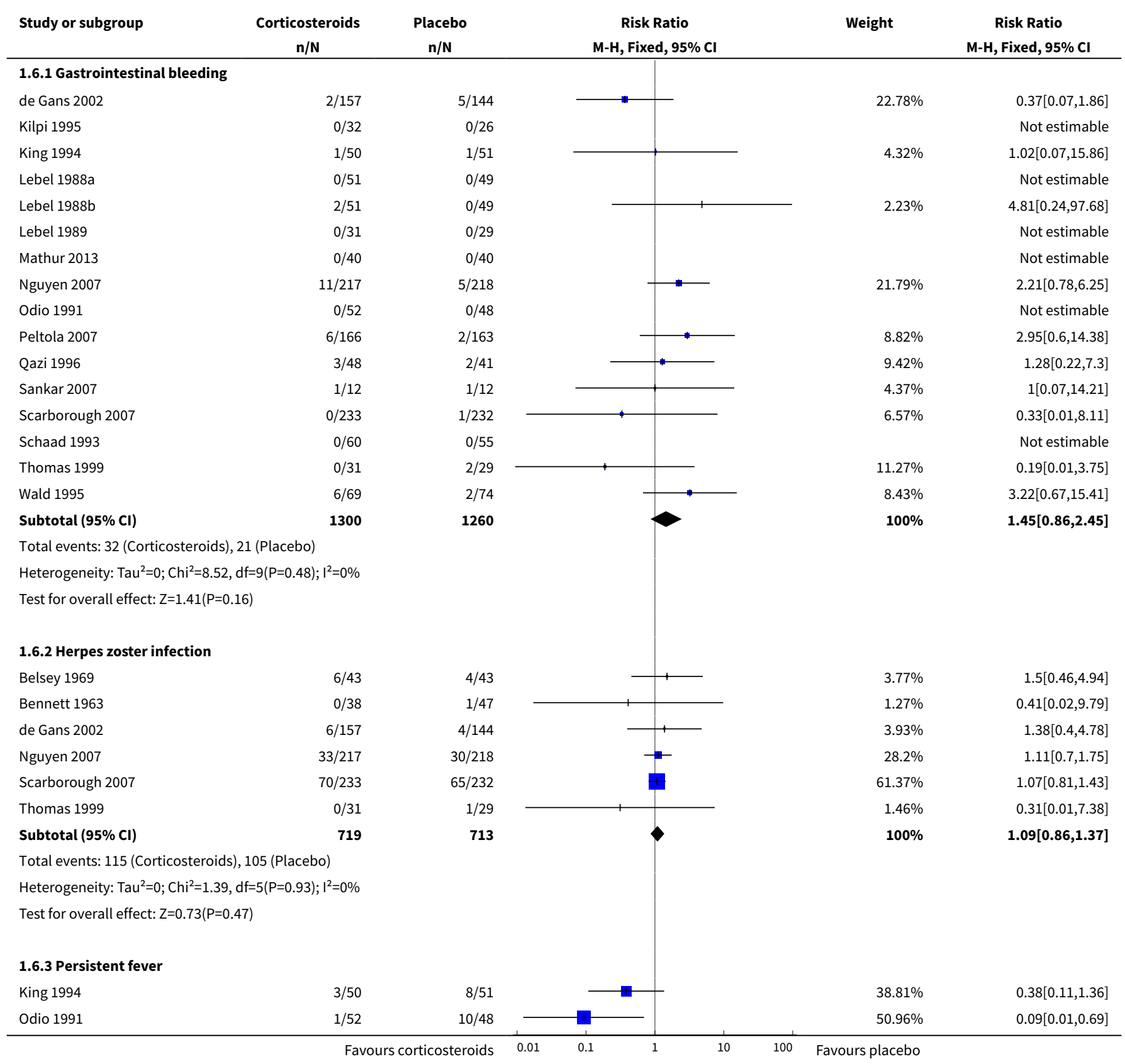




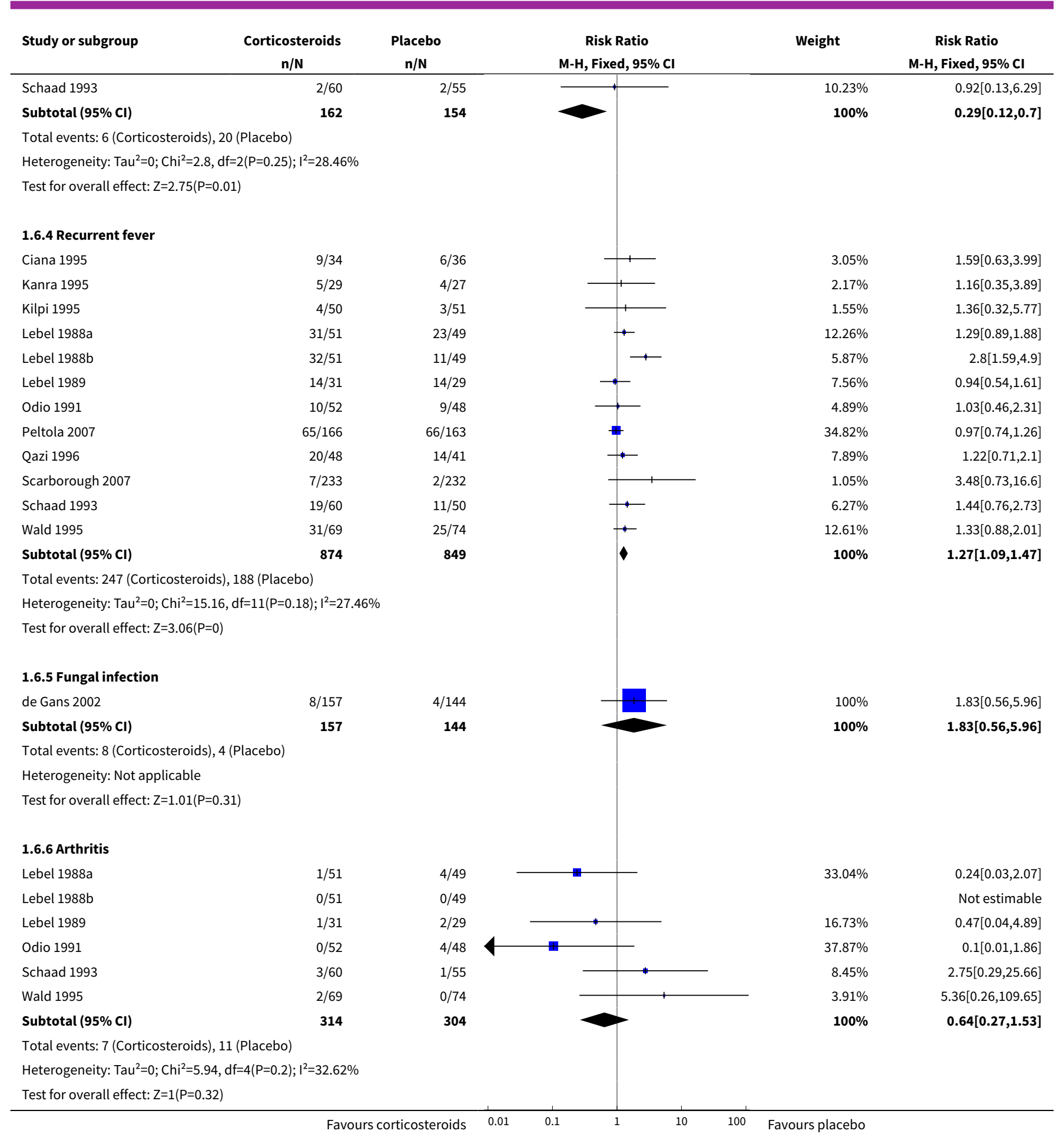




\section{Comparison 2. Children}

\begin{tabular}{lllll}
\hline Outcome or subgroup title & $\begin{array}{l}\text { No. of } \\
\text { studies }\end{array}$ & $\begin{array}{l}\text { No. of } \\
\text { partici- } \\
\text { pants }\end{array}$ & Statistical method & Effect size \\
\hline 1 Mortality & 18 & 2511 & Risk Ratio (M-H, Fixed, 95\% Cl) & $0.89[0.74,1.07]$ \\
\hline 2 Severe hearing loss & 14 & 1524 & Risk Ratio (M-H, Fixed, 95\% Cl) & $0.67[0.49,0.91]$ \\
\hline 3 Any hearing loss & 16 & 1961 & Risk Ratio (M-H, Fixed, 95\% Cl) & $0.73[0.61,0.86]$ \\
\hline
\end{tabular}

Analysis 2.1. Comparison 2 Children, Outcome 1 Mortality.

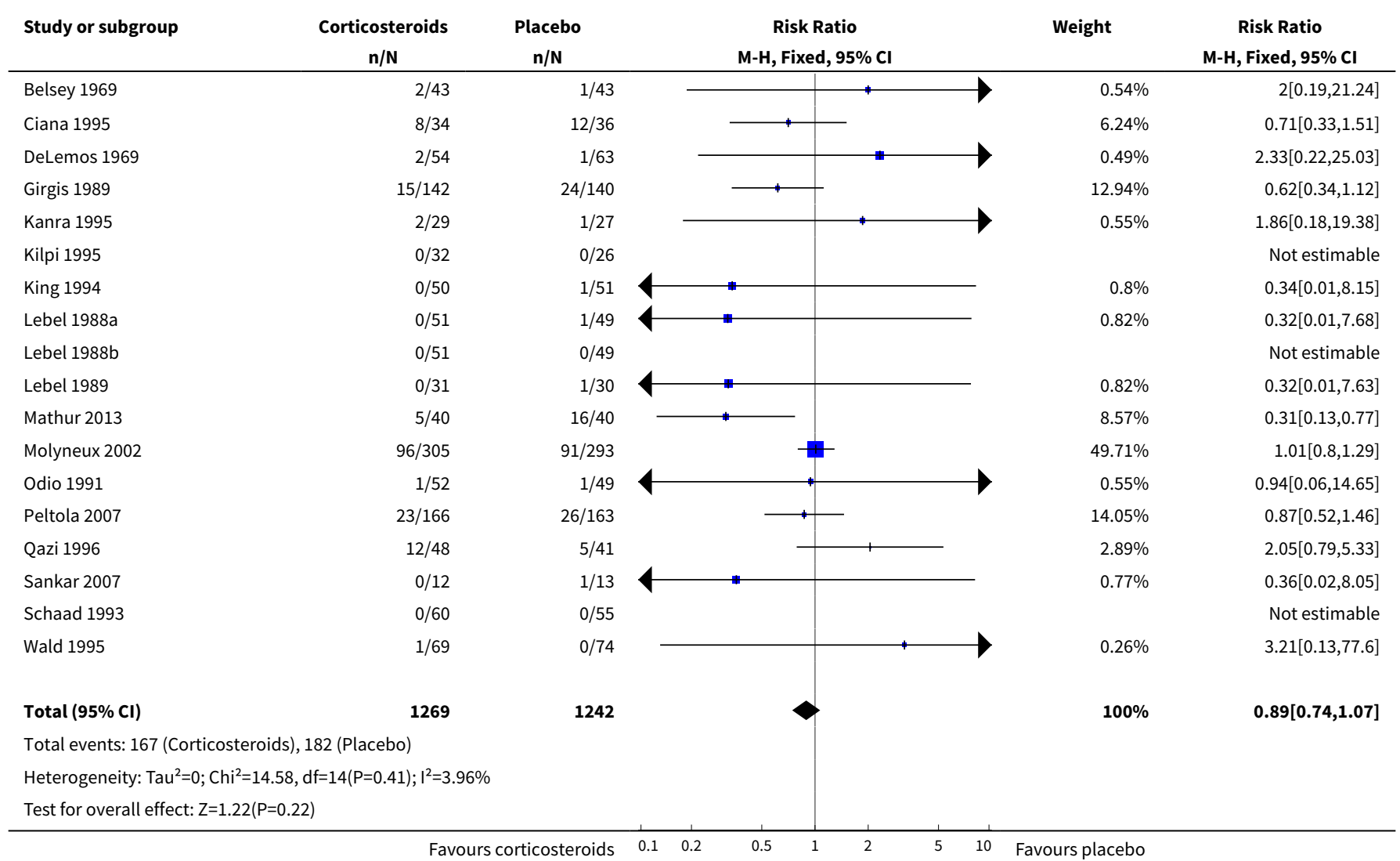

Analysis 2.2. Comparison 2 Children, Outcome 2 Severe hearing loss.

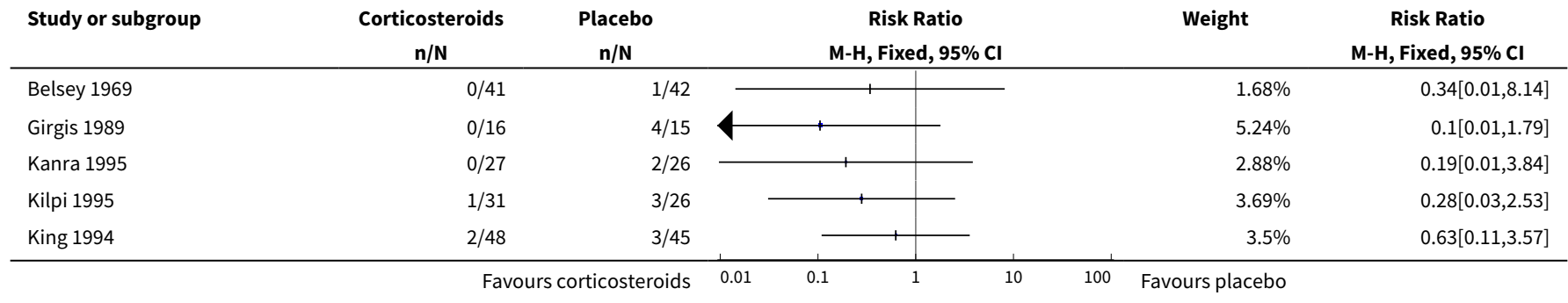




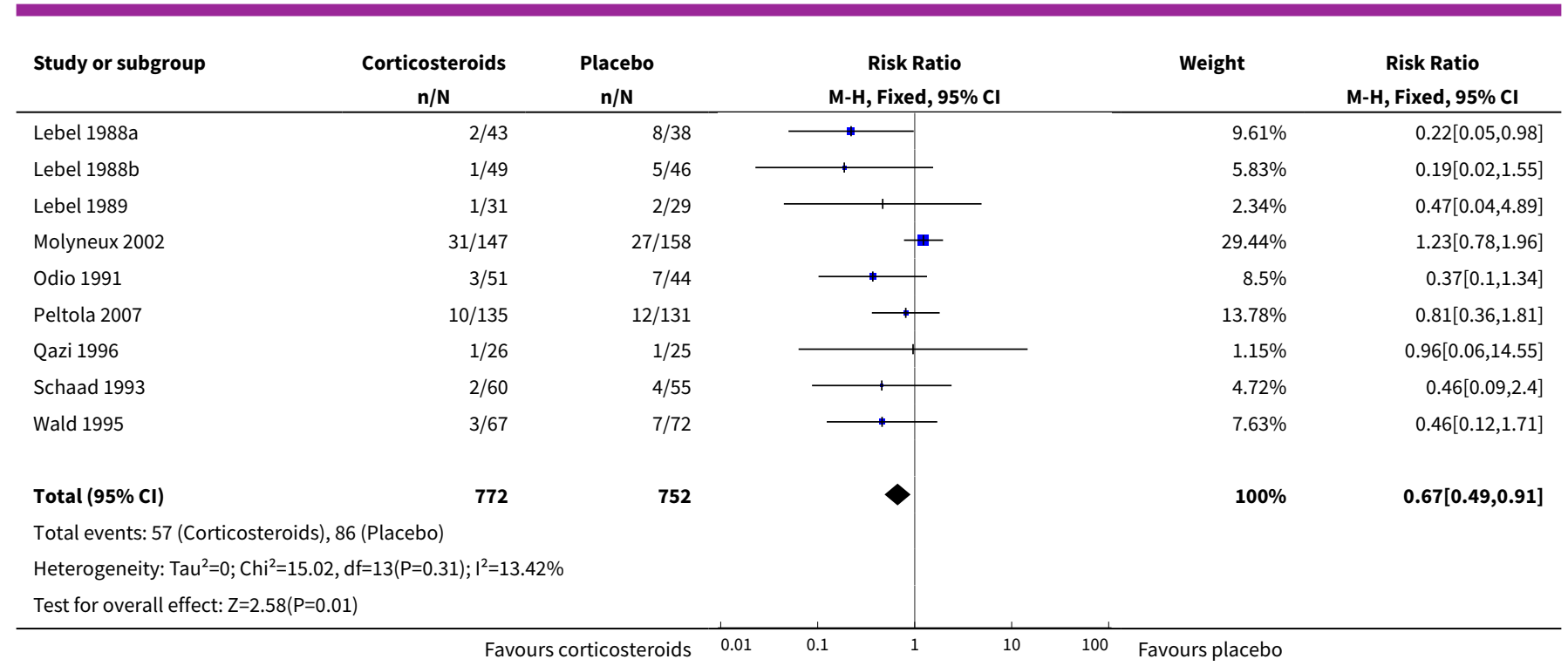

Analysis 2.3. Comparison 2 Children, Outcome 3 Any hearing loss.

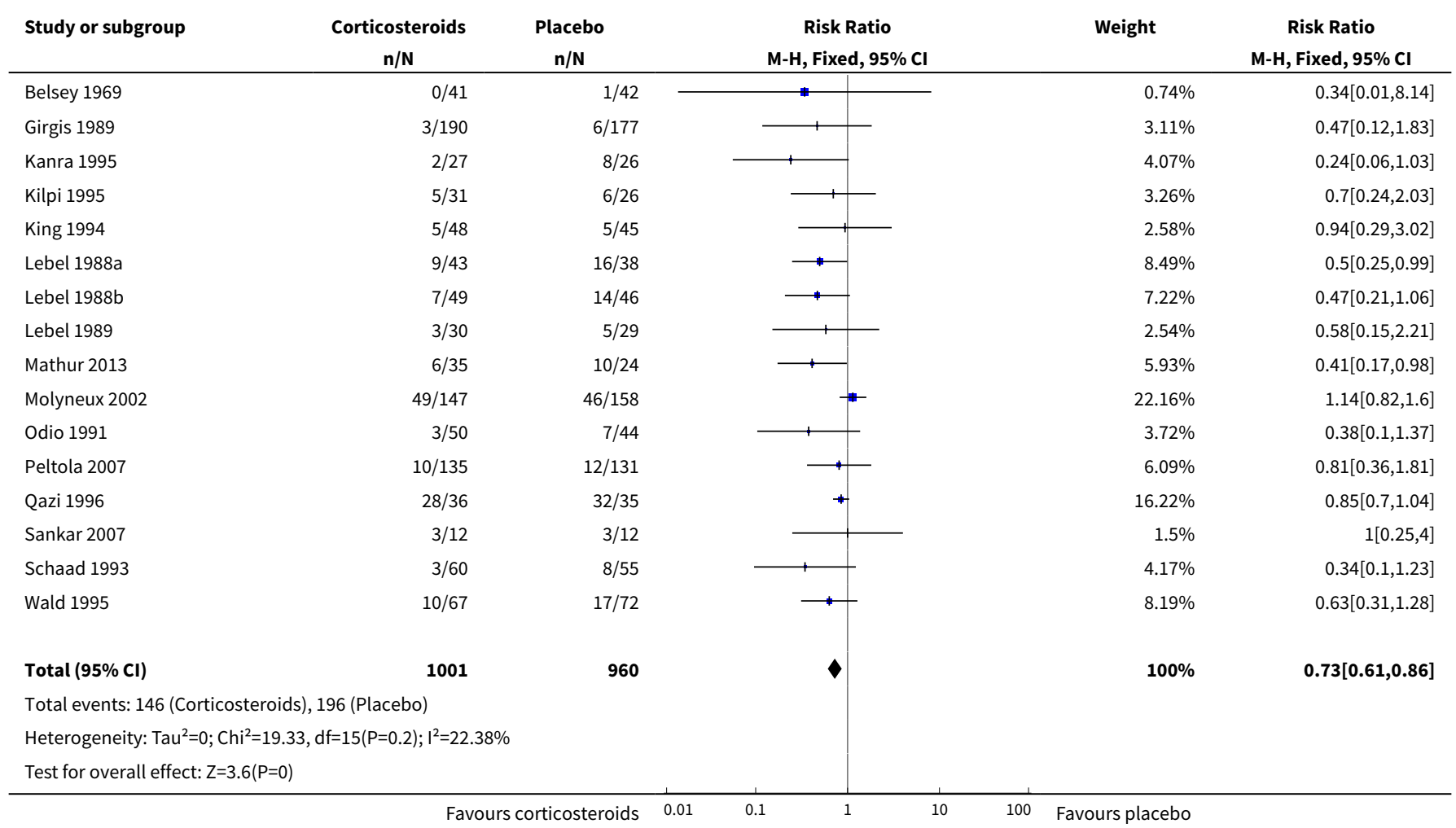




\section{Comparison 3. Adults}

\begin{tabular}{llllll}
\hline Outcome or subgroup title & $\begin{array}{l}\text { No. of } \\
\text { studies }\end{array}$ & $\begin{array}{l}\text { No. of } \\
\text { partici- } \\
\text { pants }\end{array}$ & Statistical method & Effect size \\
\hline 1 Mortality & 7 & 1517 & Risk Ratio (M-H, Random, 95\% Cl) & $0.74[0.53,1.05]$ \\
\hline 2 Any hearing loss & 4 & 844 & Risk Ratio (M-H, Fixed, 95\% Cl) & $0.74[0.56,0.98]$ \\
\hline 3 Short-term neurological sequelae & 4 & 542 & Risk Ratio (M-H, Fixed, 95\% Cl) & $0.72[0.51,1.01]$ \\
\hline
\end{tabular}

Analysis 3.1. Comparison 3 Adults, Outcome 1 Mortality.

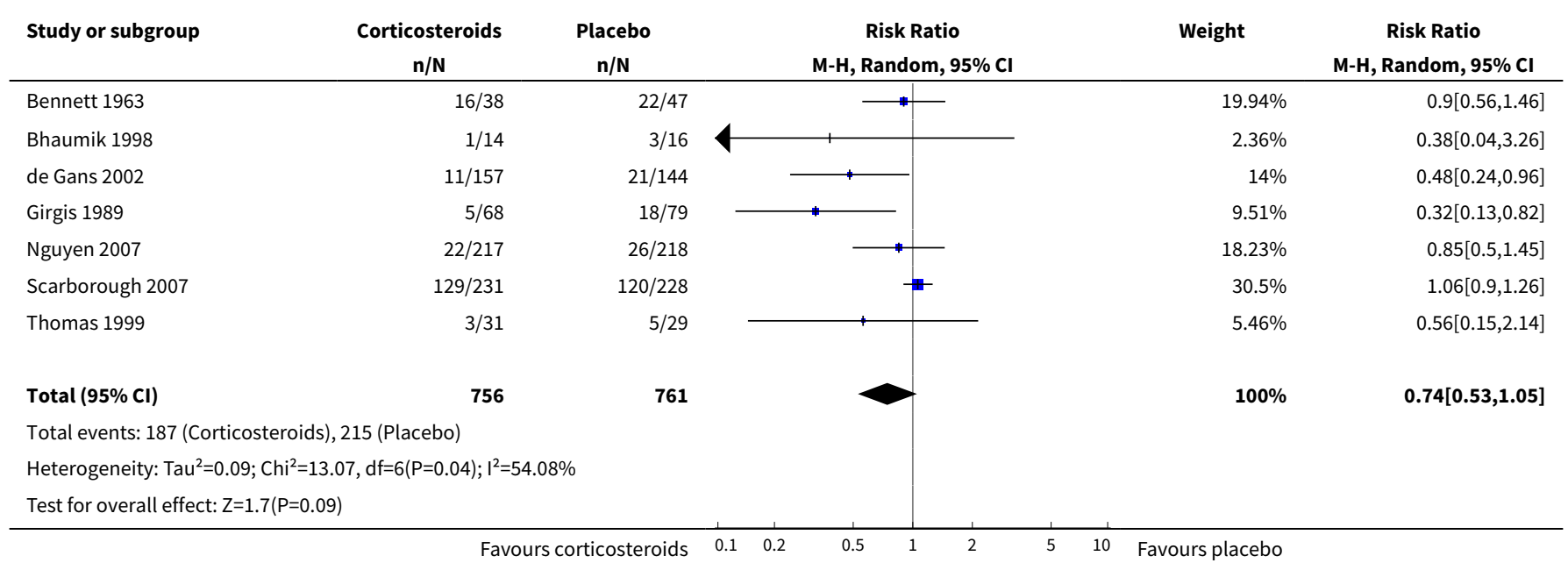

Analysis 3.2. Comparison 3 Adults, Outcome 2 Any hearing loss.

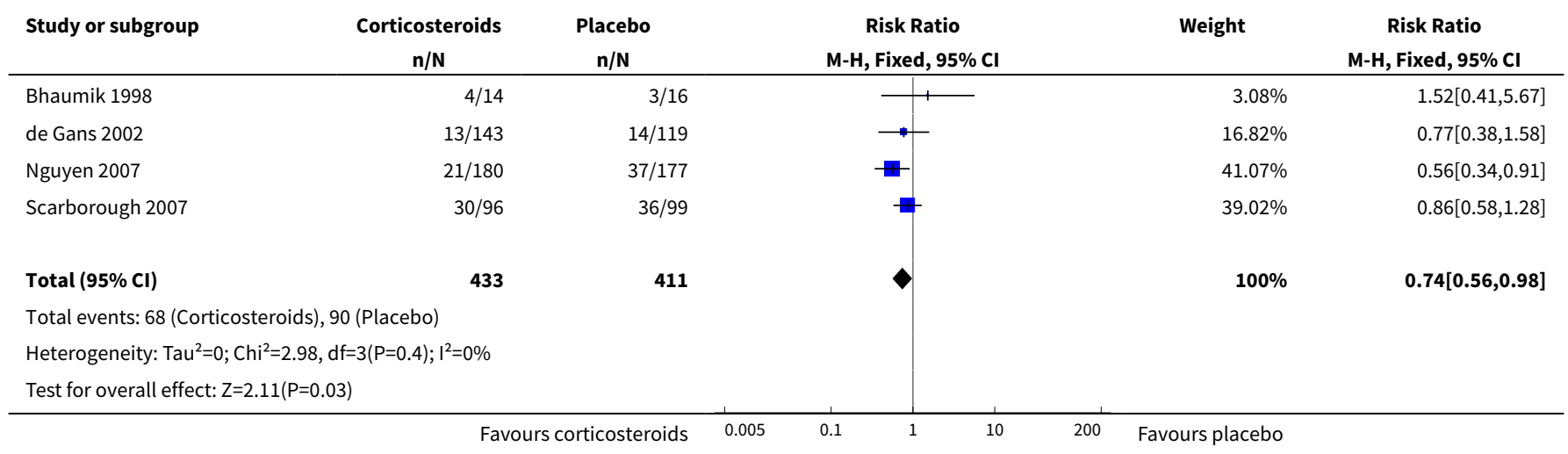


Analysis 3.3. Comparison 3 Adults, Outcome 3 Short-term neurological sequelae.

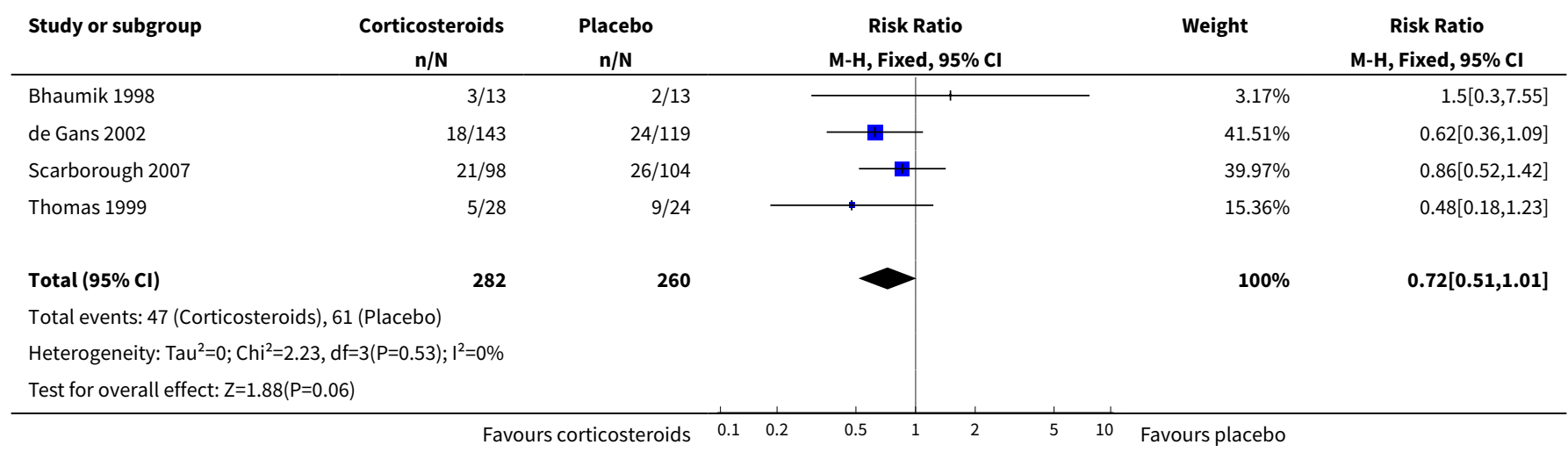

\section{Comparison 4. Causative species}

\begin{tabular}{lllll}
\hline Outcome or subgroup title & $\begin{array}{l}\text { No. of } \\
\text { studies }\end{array}$ & $\begin{array}{l}\text { No. of } \\
\text { partici- } \\
\text { pants }\end{array}$ & Statistical method & Effect size \\
\hline 1 Mortality & 18 & & Risk Ratio (M-H, Fixed, 95\% Cl) & Subtotals only \\
\hline 1.1 Haemophilus influenzae & 11 & 825 & Risk Ratio (M-H, Fixed, 95\% Cl) & $0.76[0.53,1.09]$ \\
\hline $\begin{array}{lllll}1.2 \text { Streptococcus pneumoniae } \\
\text { 1.3 Neisseria meningitidis }\end{array}$ & 17 & 1132 & Risk Ratio (M-H, Fixed, 95\% Cl) & $0.84[0.72,0.98]$ \\
\hline $\begin{array}{l}\text { 2 Severe hearing loss in children - } \\
\text { non-Haemophilus influenzae species }\end{array}$ & 13 & 618 & Risk Ratio (M-H, Fixed, 95\% Cl) & $0.71[0.35,1.46]$ \\
\hline $\begin{array}{l}\text { 3 Severe hearing loss in children - } \\
\text { Haemophilus influenzae }\end{array}$ & 10 & 860 & Risk Ratio (M-H, Fixed, 95\% Cl) & $0.95[0.65,1.39]$ \\
\hline
\end{tabular}

Analysis 4.1. Comparison 4 Causative species, Outcome 1 Mortality.

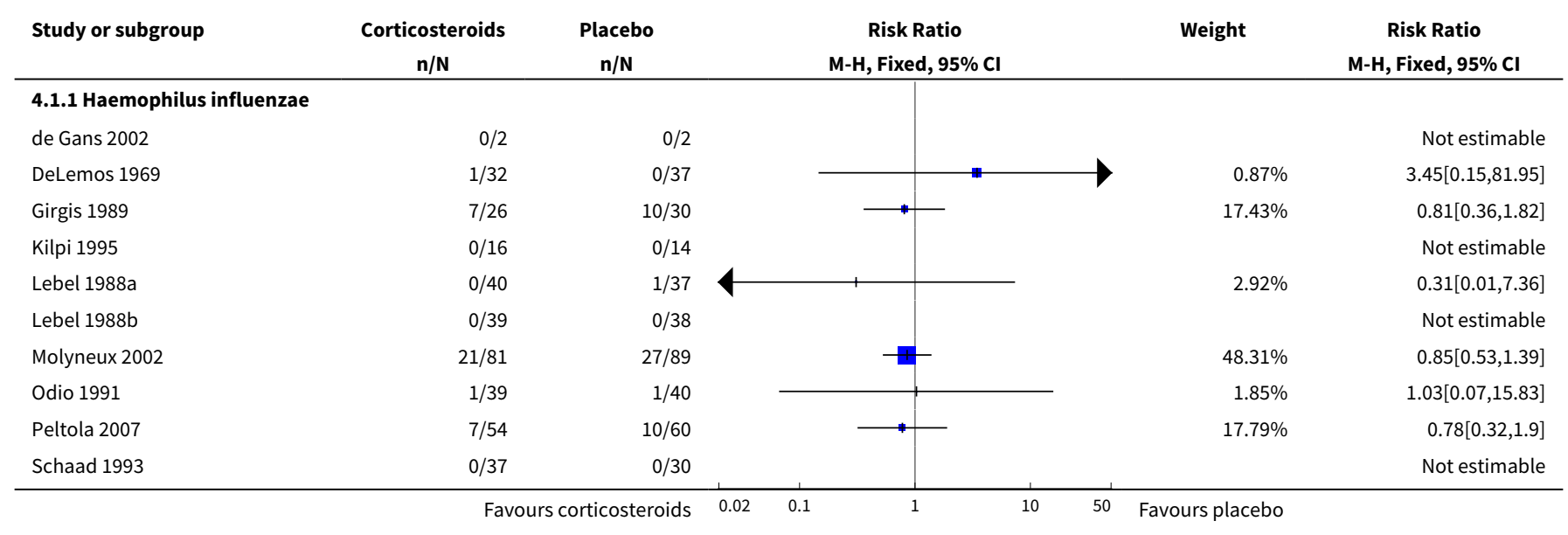




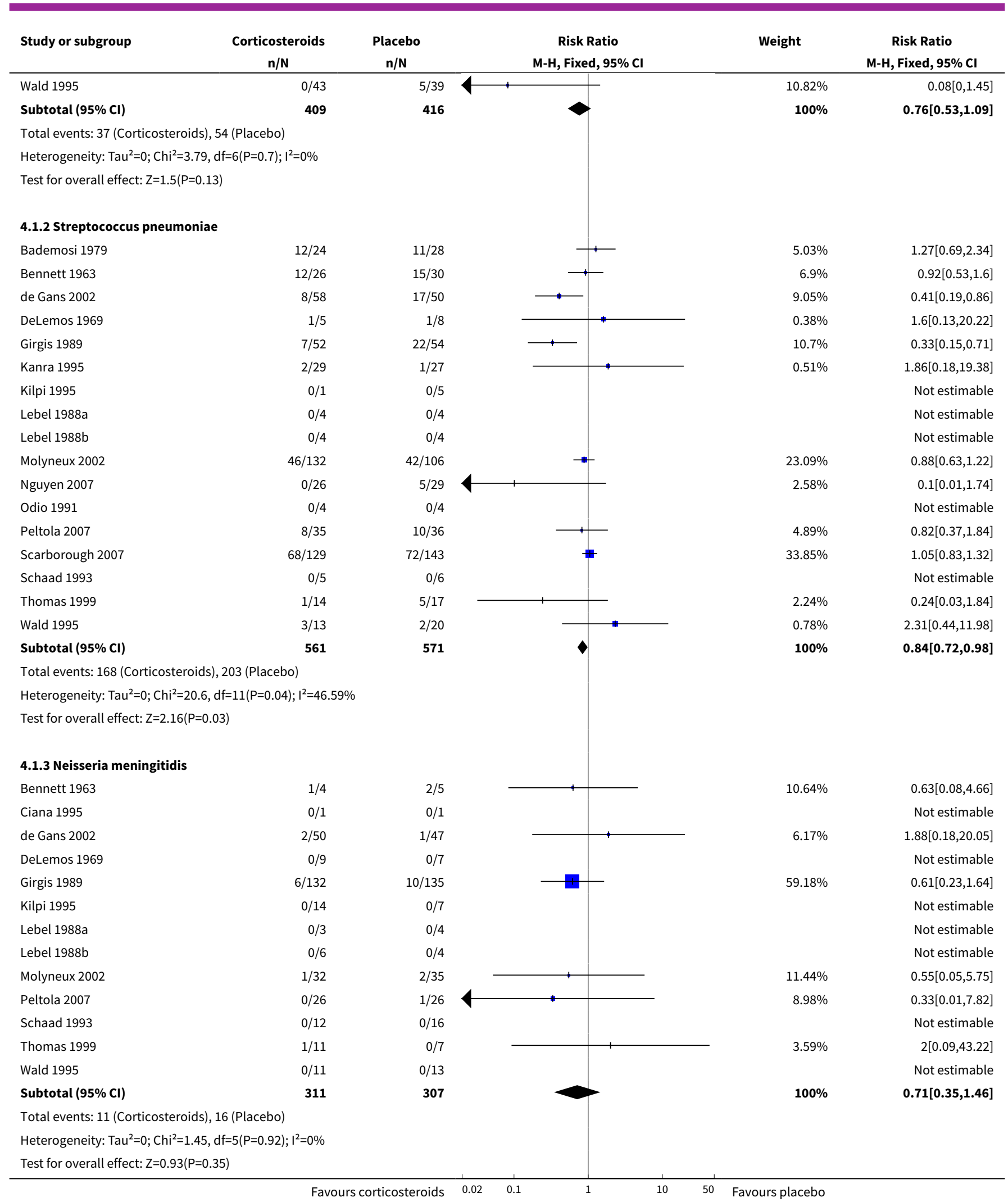


Analysis 4.2. Comparison 4 Causative species, Outcome 2 Severe hearing loss in children - non-Haemophilus influenzae species.

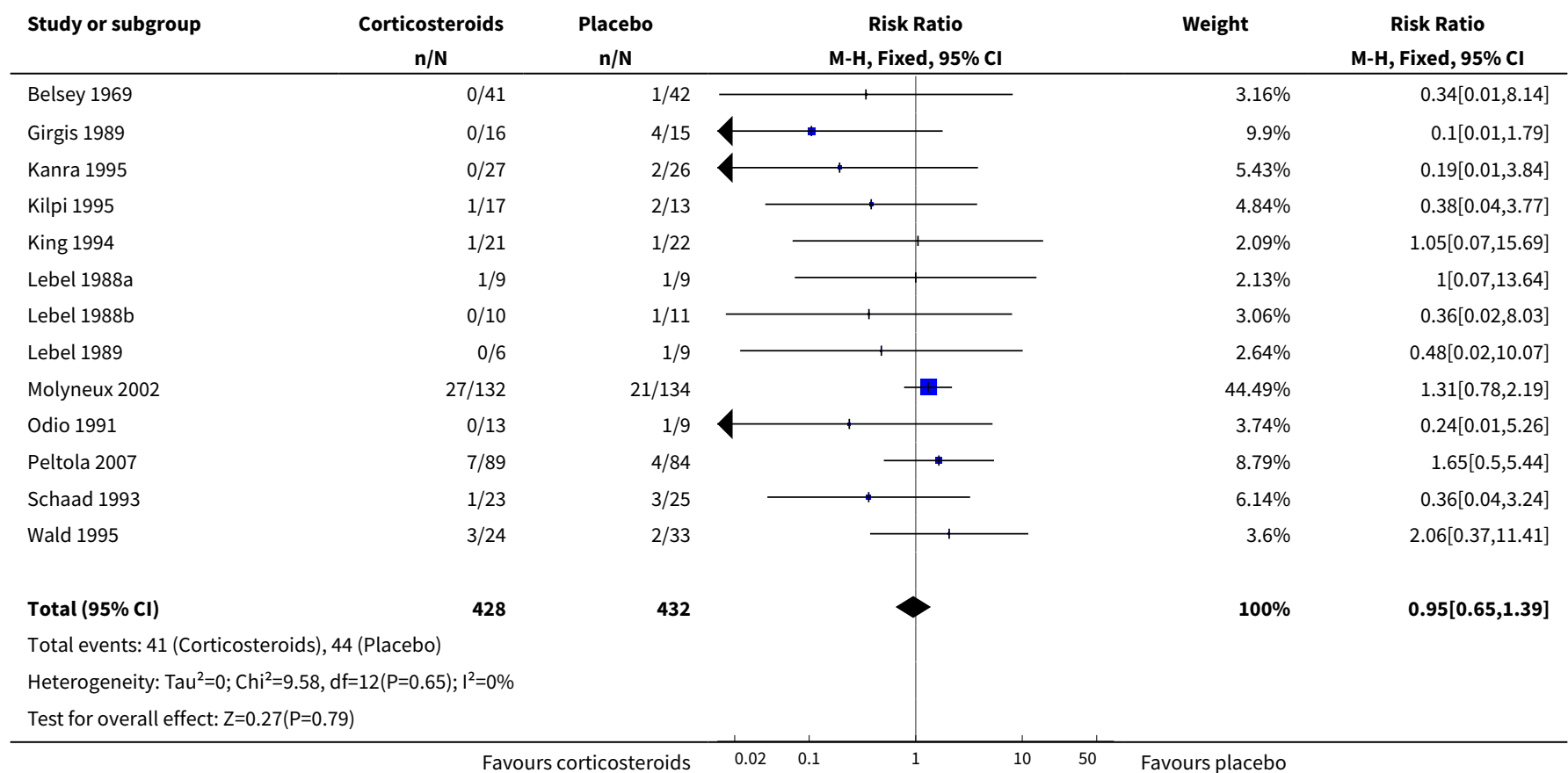

Analysis 4.3. Comparison 4 Causative species, Outcome 3 Severe hearing loss in children - Haemophilus influenzae.

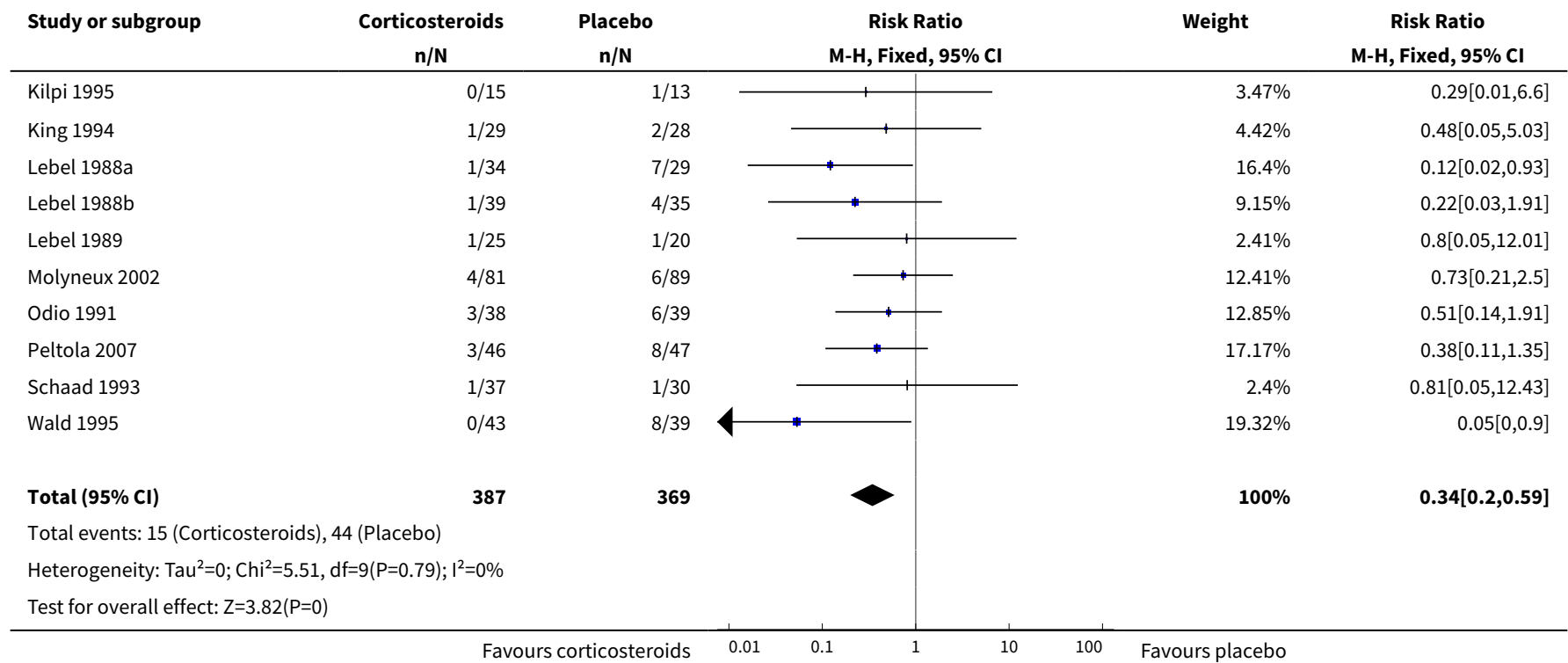




\section{Comparison 5. Income of countries}

\begin{tabular}{|c|c|c|c|c|}
\hline Outcome or subgroup title & $\begin{array}{l}\text { No. of } \\
\text { studies }\end{array}$ & $\begin{array}{l}\text { No. of } \\
\text { partici- } \\
\text { pants }\end{array}$ & Statistical method & Effect size \\
\hline 1 Mortality - all patients & 25 & 4121 & $\begin{array}{l}\text { Risk Ratio (IV, Random, 95\% } \\
\mathrm{Cl} \text { ) }\end{array}$ & $0.88[0.75,1.03]$ \\
\hline 1.1 Low-income countries & 9 & 1873 & $\begin{array}{l}\text { Risk Ratio (IV, Random, 95\% } \\
\mathrm{Cl} \text { ) }\end{array}$ & $0.87[0.67,1.15]$ \\
\hline 1.2 High-income countries & 16 & 2248 & $\begin{array}{l}\text { Risk Ratio (IV, Random, 95\% } \\
\mathrm{Cl} \text { ) }\end{array}$ & $0.81[0.63,1.05]$ \\
\hline 2 Severe hearing loss - all patients & 17 & 2445 & Risk Ratio (IV, Fixed, 95\% CI) & $0.74[0.58,0.94]$ \\
\hline 2.1 Low-income countries & 5 & 944 & Risk Ratio (IV, Fixed, 95\% CI) & $0.99[0.72,1.38]$ \\
\hline 2.2 High-income countries & 12 & 1501 & Risk Ratio (IV, Fixed, 95\% CI) & $0.51[0.35,0.73]$ \\
\hline 3 Any hearing loss & 20 & 2805 & Risk Ratio (IV, Fixed, 95\% CI) & $0.79[0.69,0.89]$ \\
\hline 3.1 Low-income countries & 7 & 1051 & Risk Ratio (IV, Fixed, 95\% CI) & $0.89[0.76,1.04]$ \\
\hline 3.2 High-income countries & 13 & 1754 & Risk Ratio (IV, Fixed, 95\% CI) & $0.58[0.45,0.73]$ \\
\hline $\begin{array}{l}4 \text { Short-term neurological sequelae - all pa- } \\
\text { tients }\end{array}$ & 14 & 1814 & Risk Ratio (IV, Fixed, 95\% CI) & $0.84[0.70,1.02]$ \\
\hline 4.1 Low-income countries & 5 & 735 & Risk Ratio (IV, Fixed, 95\% CI) & $1.03[0.81,1.31]$ \\
\hline 4.2 High-income countries & 9 & 1079 & Risk Ratio (IV, Fixed, 95\% CI) & $0.64[0.48,0.85]$ \\
\hline 5 Mortality - children & 17 & 2486 & Risk Ratio (IV, Fixed, 95\% CI) & $0.92[0.77,1.11]$ \\
\hline 5.1 Low-income countries & 5 & 1119 & Risk Ratio (IV, Fixed, 95\% CI) & $0.91[0.75,1.12]$ \\
\hline 5.2 High-income countries & 12 & 1367 & Risk Ratio (IV, Fixed, 95\% CI) & $0.96[0.61,1.50]$ \\
\hline 6 Severe hearing loss - children & 14 & 1531 & Risk Ratio (IV, Fixed, 95\% CI) & $0.74[0.56,0.98]$ \\
\hline 6.1 Low-income countries & 3 & 387 & Risk Ratio (IV, Fixed, 95\% CI) & $1.00[0.69,1.47]$ \\
\hline 6.2 High-income countries & 11 & 1144 & Risk Ratio (IV, Fixed, 95\% CI) & $0.52[0.35,0.78]$ \\
\hline $\begin{array}{l}7 \text { Short-term neurological sequelae - chil- } \\
\text { dren }\end{array}$ & 10 & 1271 & Risk Ratio (IV, Fixed, 95\% CI) & $0.90[0.72,1.13]$ \\
\hline 7.1 Low-income countries & 3 & 506 & Risk Ratio (IV, Fixed, 95\% CI) & $1.08[0.81,1.43]$ \\
\hline 7.2 High-income countries & 7 & 765 & Risk Ratio (IV, Fixed, 95\% CI) & $0.67[0.46,0.97]$ \\
\hline $\begin{array}{l}8 \text { Severe hearing loss in children due to } \\
\text { non-Haemophilus influenzae species }\end{array}$ & 13 & 862 & Risk Ratio (IV, Fixed, 95\% CI) & $0.97[0.66,1.42]$ \\
\hline 8.1 Low-income countries & 2 & 297 & Risk Ratio (IV, Fixed, 95\% CI) & $1.20[0.72,2.00]$ \\
\hline
\end{tabular}




\begin{tabular}{llllll}
\hline Outcome or subgroup title & $\begin{array}{l}\text { No. of } \\
\text { studies }\end{array}$ & $\begin{array}{l}\text { No. of } \\
\text { partici- } \\
\text { pants }\end{array}$ & Statistical method & Effect size \\
\hline 8.2 High-income countries & 11 & 565 & Risk Ratio (IV, Fixed, 95\% Cl) & $0.73[0.41,1.31]$ \\
\hline 9 Mortality - adults & 7 & 1517 & Risk Ratio (IV, Fixed, 95\% Cl) & $0.95[0.82,1.10]$ \\
\hline 9.1 Low-income countries & 3 & 636 & Risk Ratio (IV, Fixed, 95\% Cl) & $1.02[0.86,1.20]$ \\
\hline 9.2 High-income countries & 4 & 881 & Risk Ratio (IV, Fixed, 95\% Cl) & $0.76[0.56,1.04]$ \\
\hline 10 Any hearing loss adults & 4 & 844 & Odds Ratio (IV, Fixed, 95\% Cl) & $0.68[0.47,0.98]$ \\
\hline 10.1 Low-income countries & 2 & 225 & Odds Ratio (IV, Fixed, 95\% Cl) & $0.87[0.49,1.52]$ \\
\hline 10.2 High-income countries & 2 & 619 & Odds Ratio (IV, Fixed, 95\% Cl) & $0.58[0.36,0.92]$ \\
\hline
\end{tabular}

Analysis 5.1. Comparison 5 Income of countries, Outcome 1 Mortality - all patients.

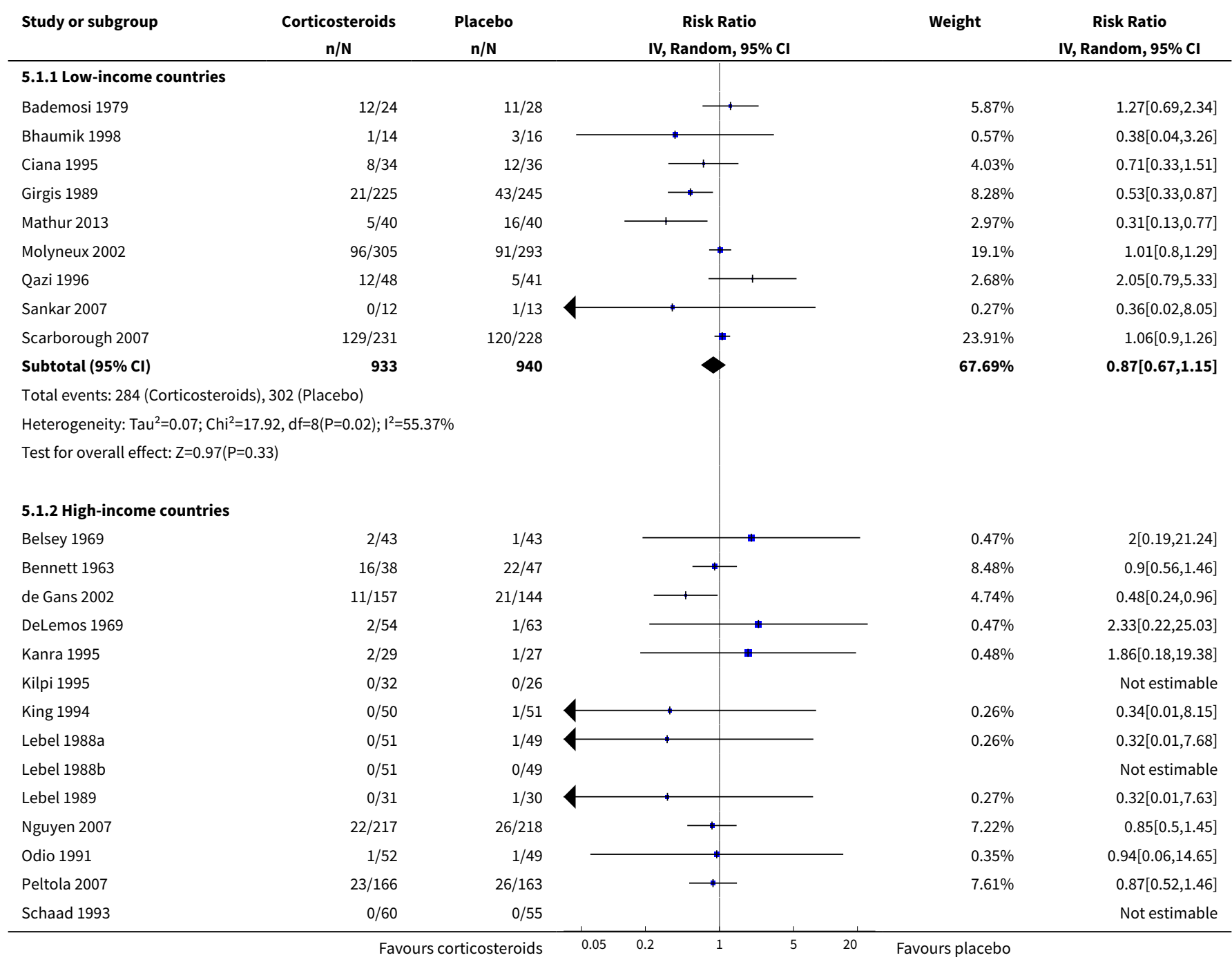




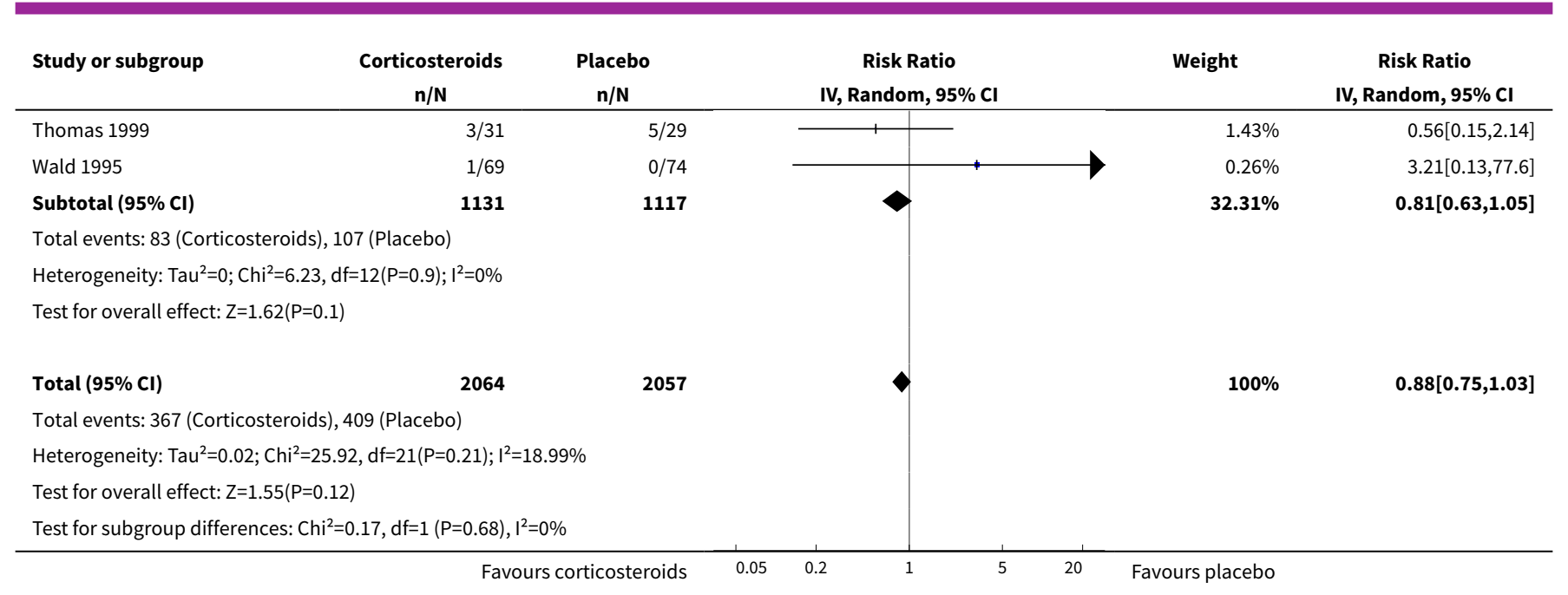

Analysis 5.2. Comparison 5 Income of countries, Outcome 2 Severe hearing loss - all patients.

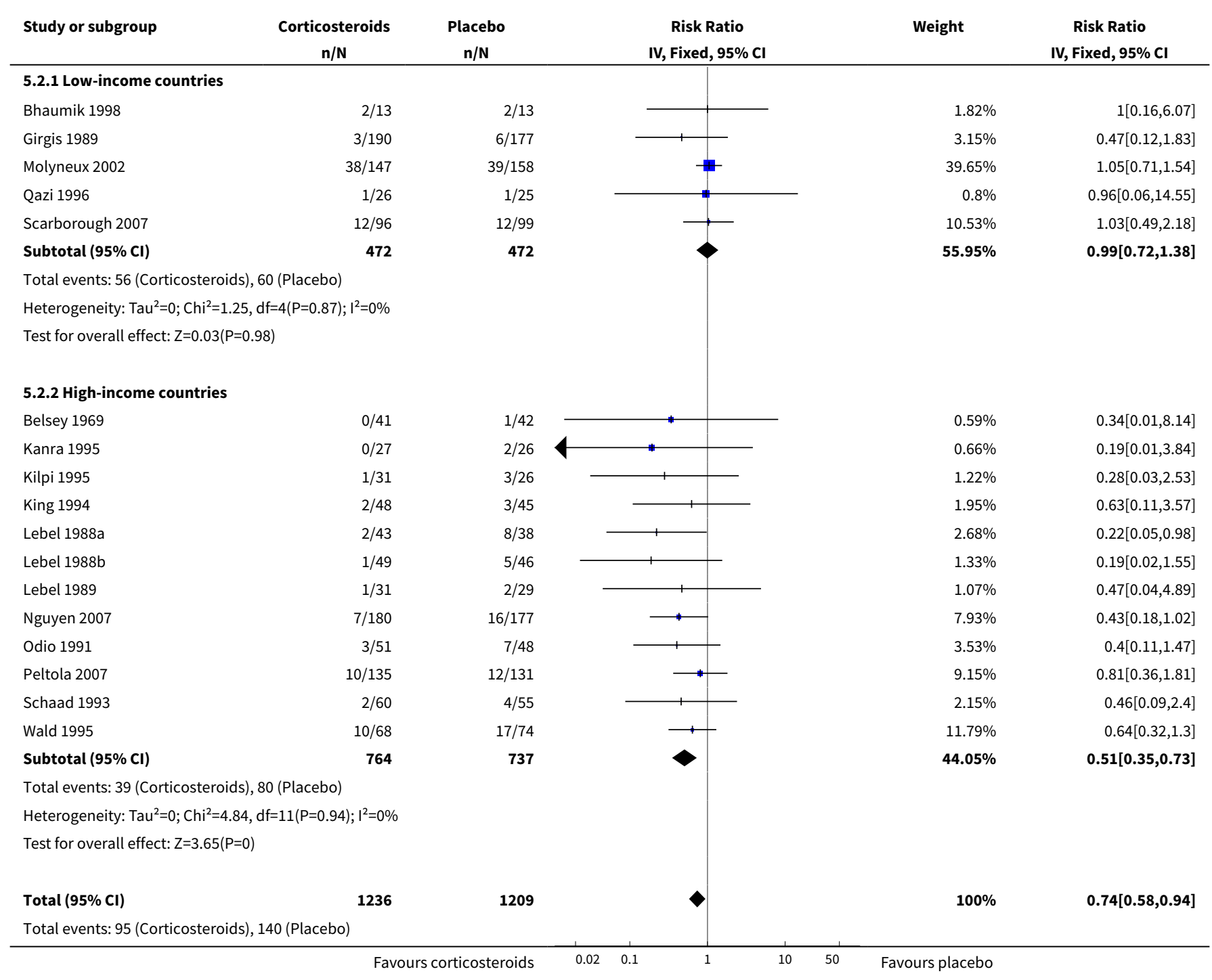




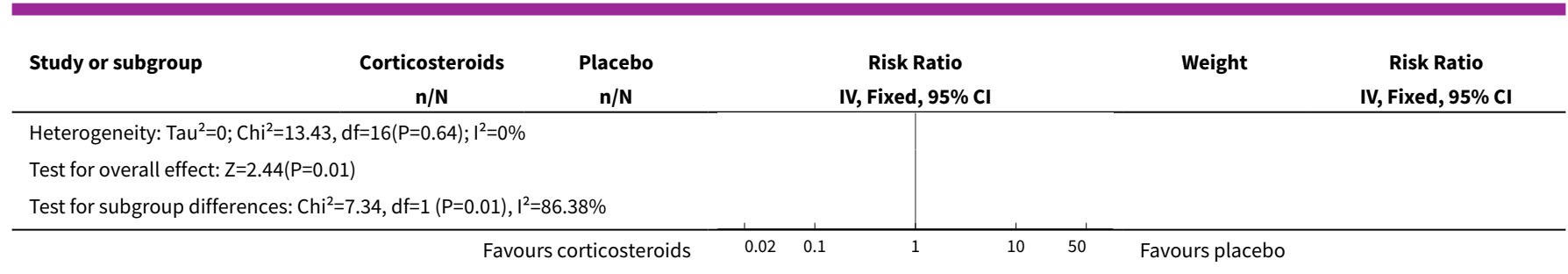

Analysis 5.3. Comparison 5 Income of countries, Outcome 3 Any hearing loss.

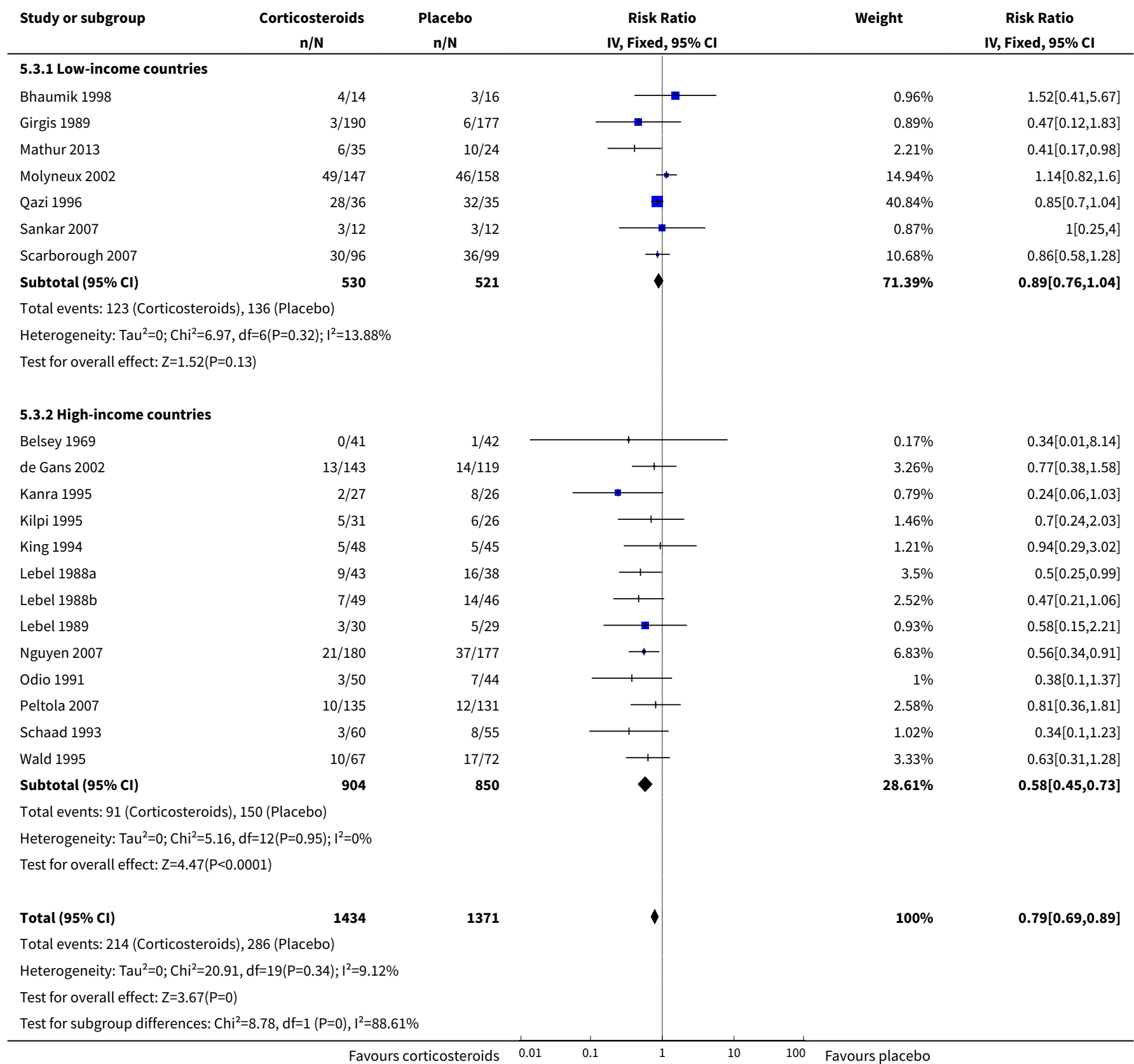


Analysis 5.4. Comparison 5 Income of countries, Outcome 4 Short-term neurological sequelae - all patients.

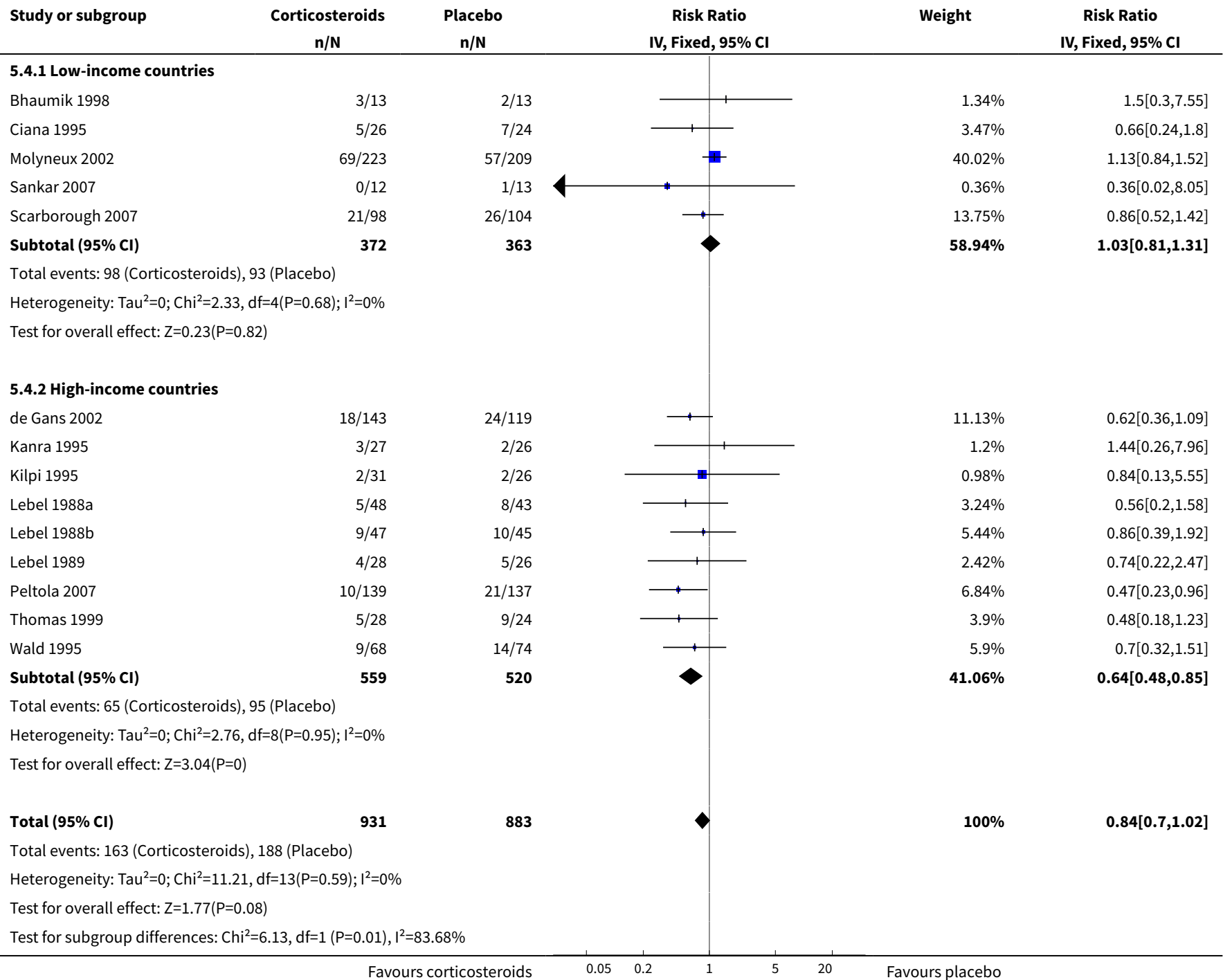

Analysis 5.5. Comparison 5 Income of countries, Outcome 5 Mortality - children.

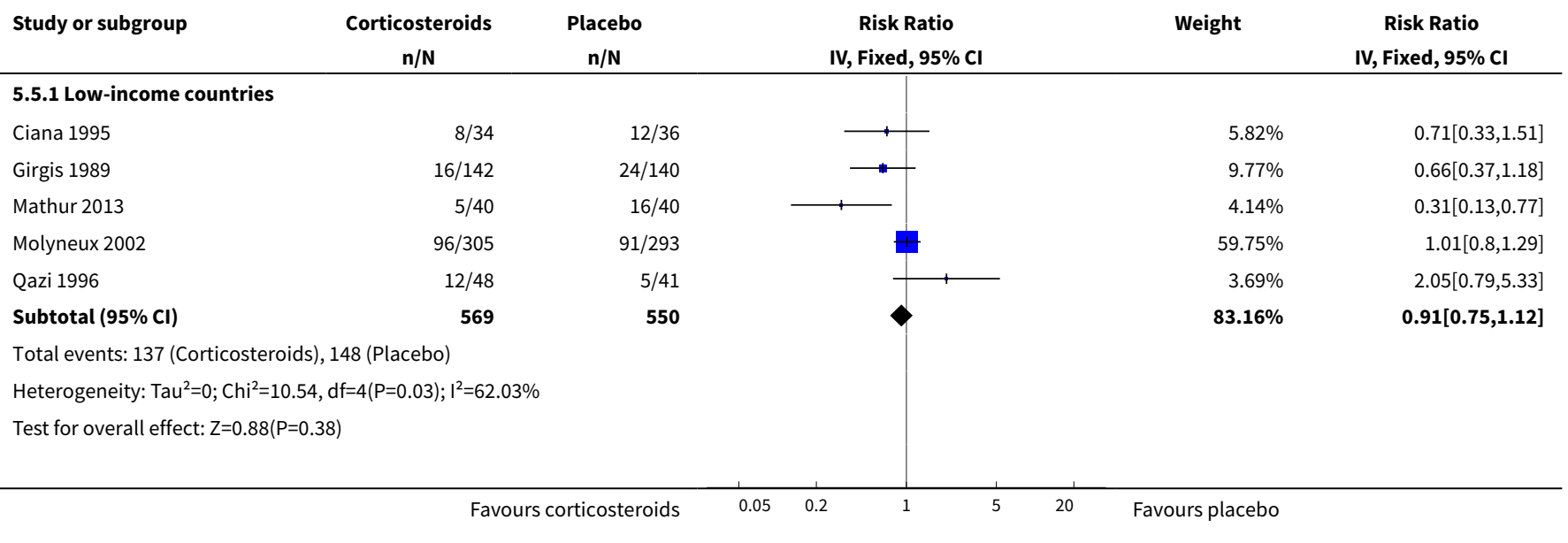




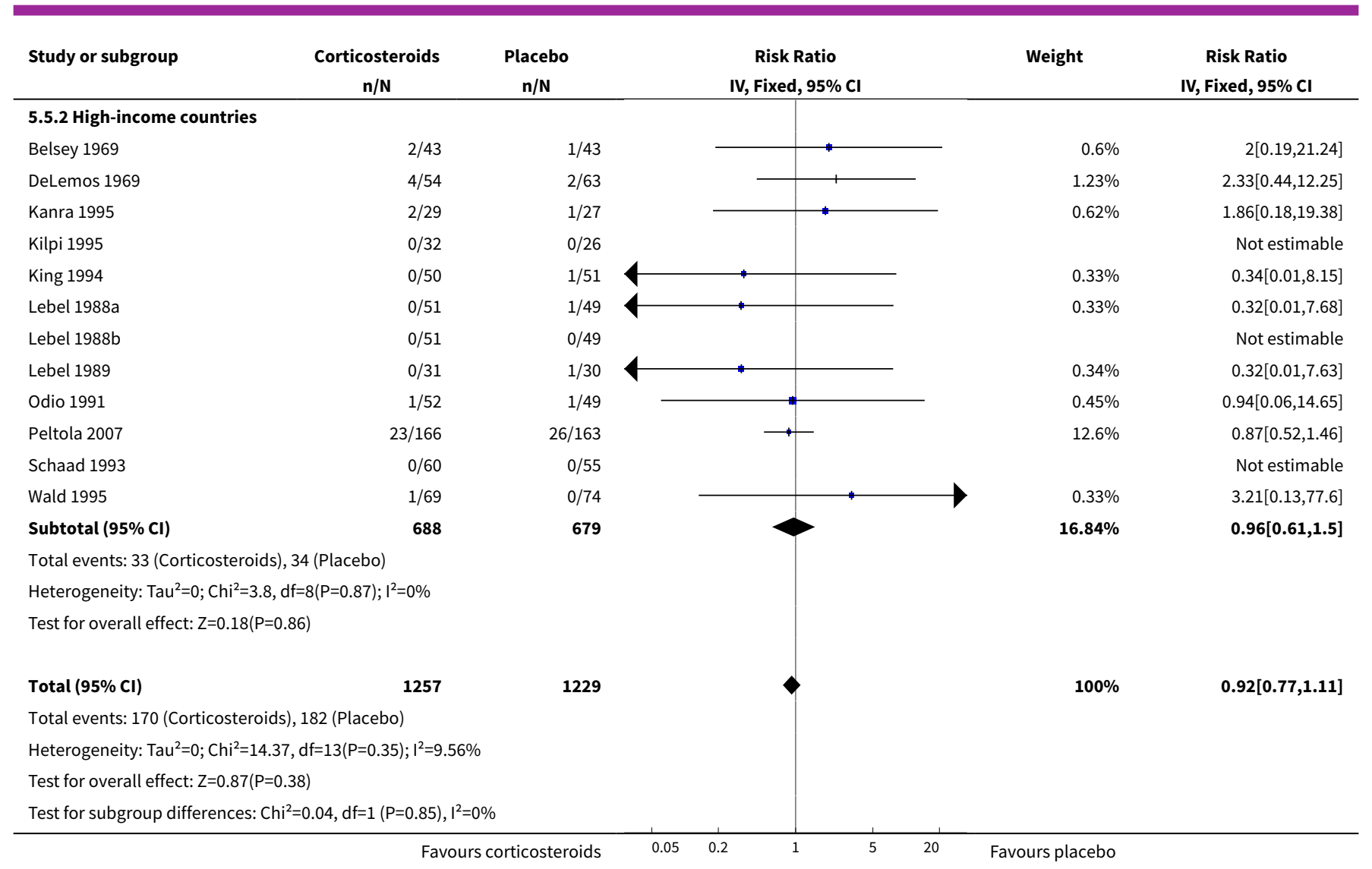

Analysis 5.6. Comparison 5 Income of countries, Outcome 6 Severe hearing loss - children.

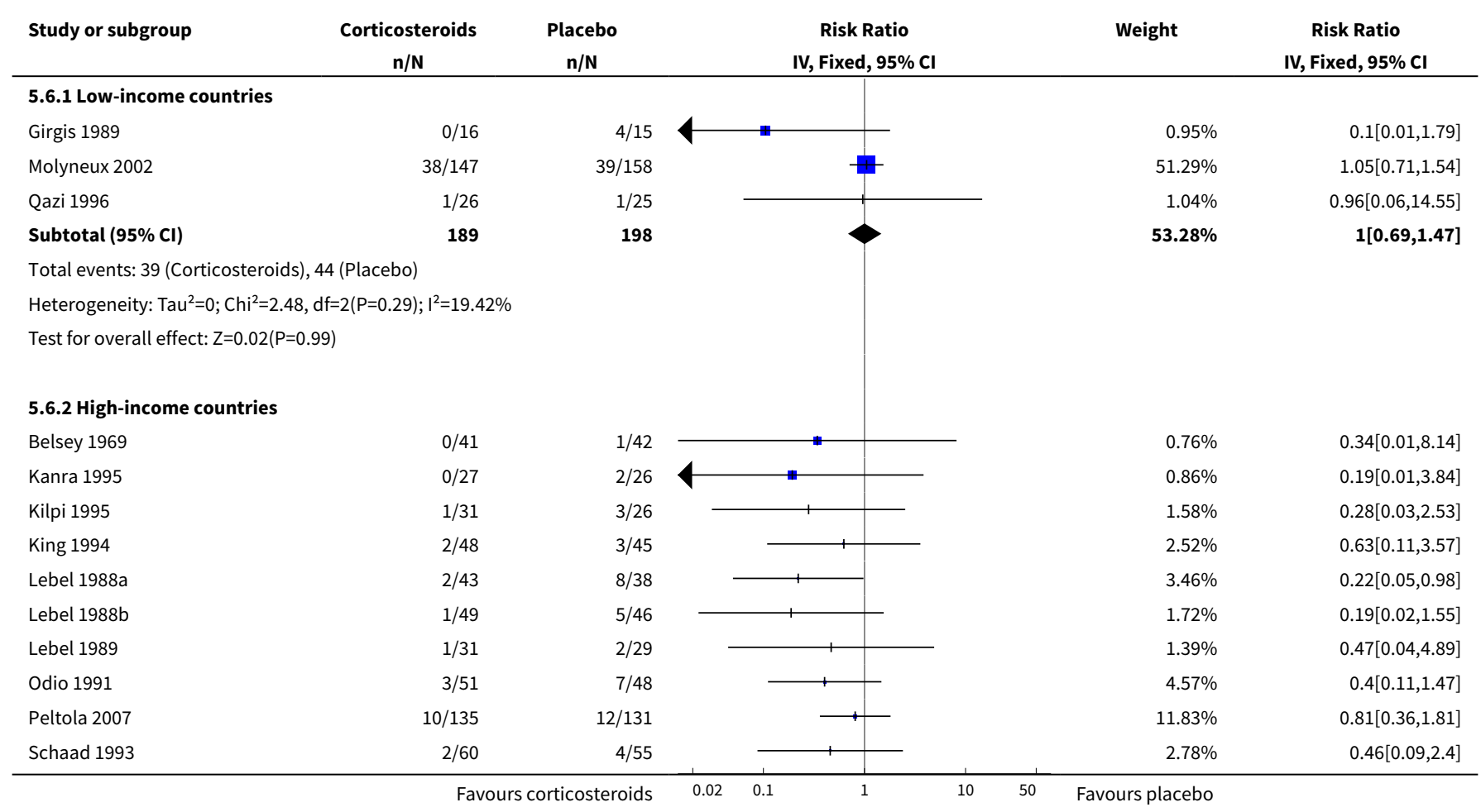




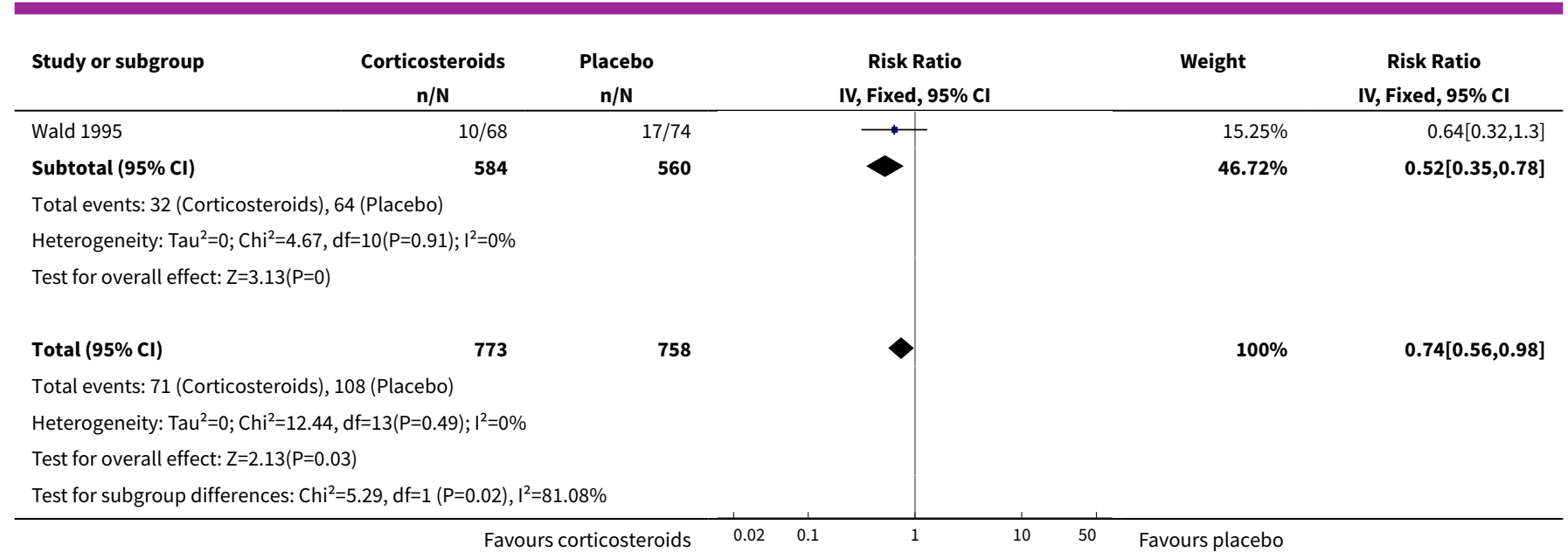

Analysis 5.7. Comparison 5 Income of countries, Outcome 7 Short-term neurological sequelae - children.

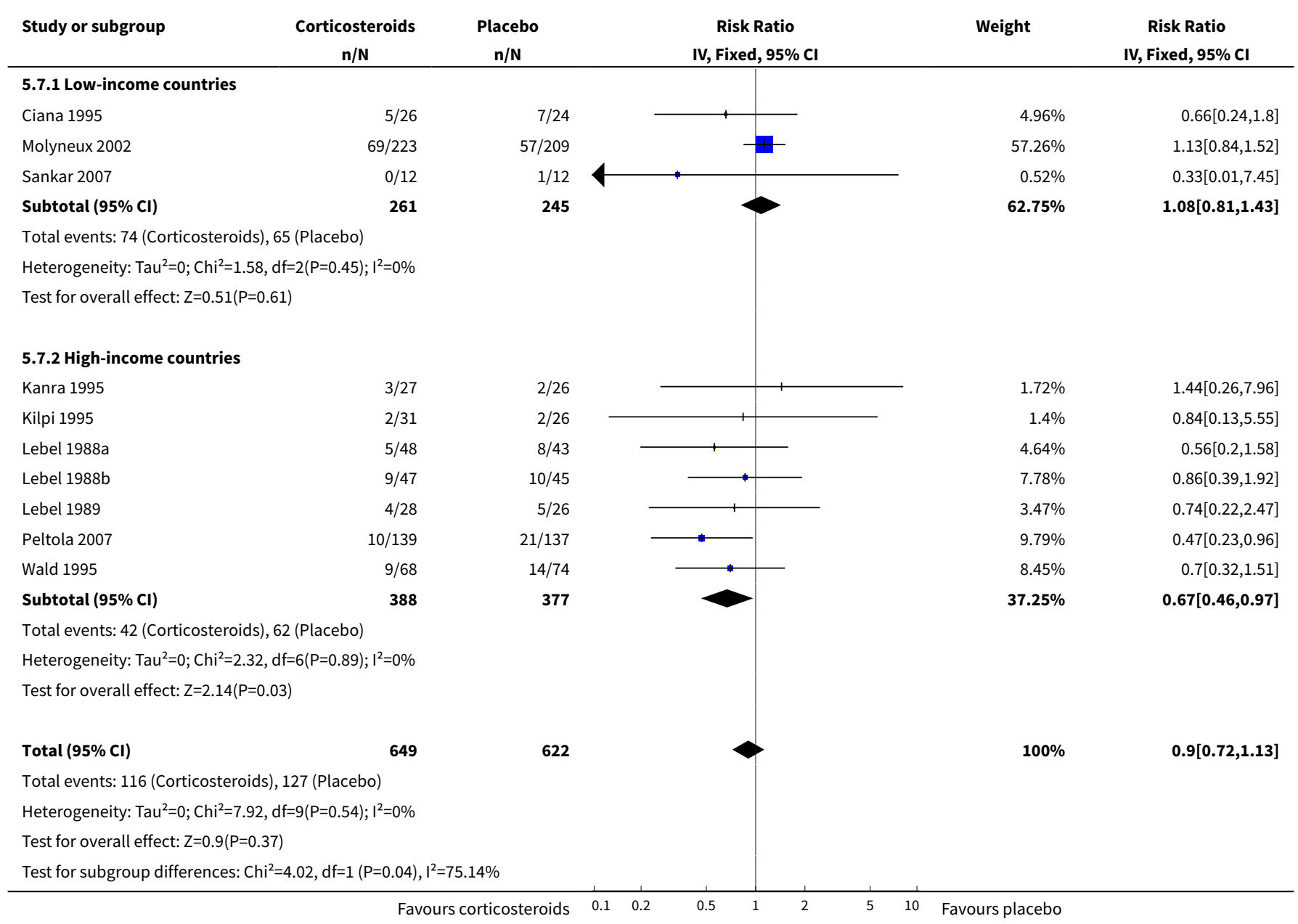


Analysis 5.8. Comparison 5 Income of countries, Outcome 8 Severe hearing loss in children due to non-Haemophilus influenzae species.

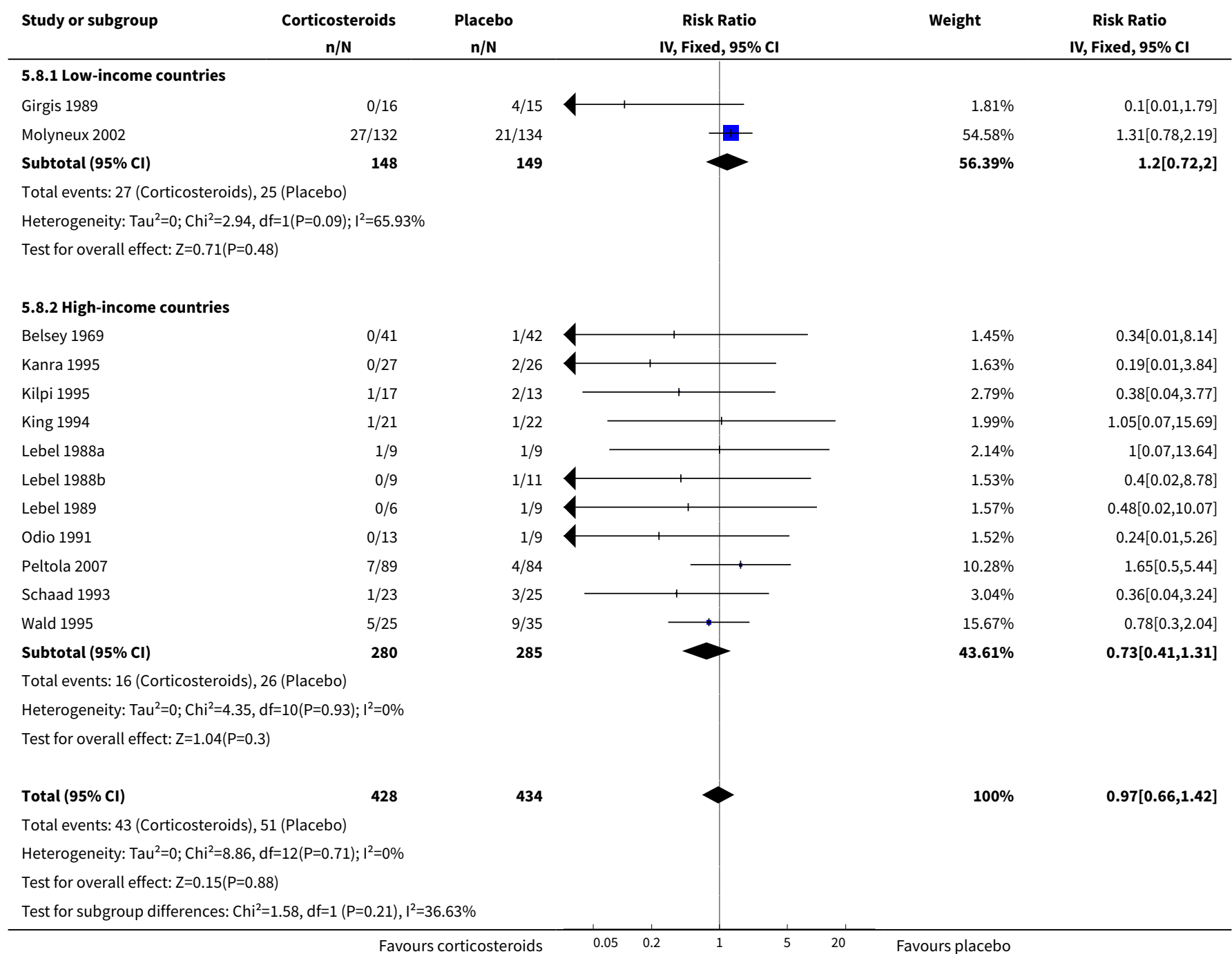

Analysis 5.9. Comparison 5 Income of countries, Outcome 9 Mortality - adults.

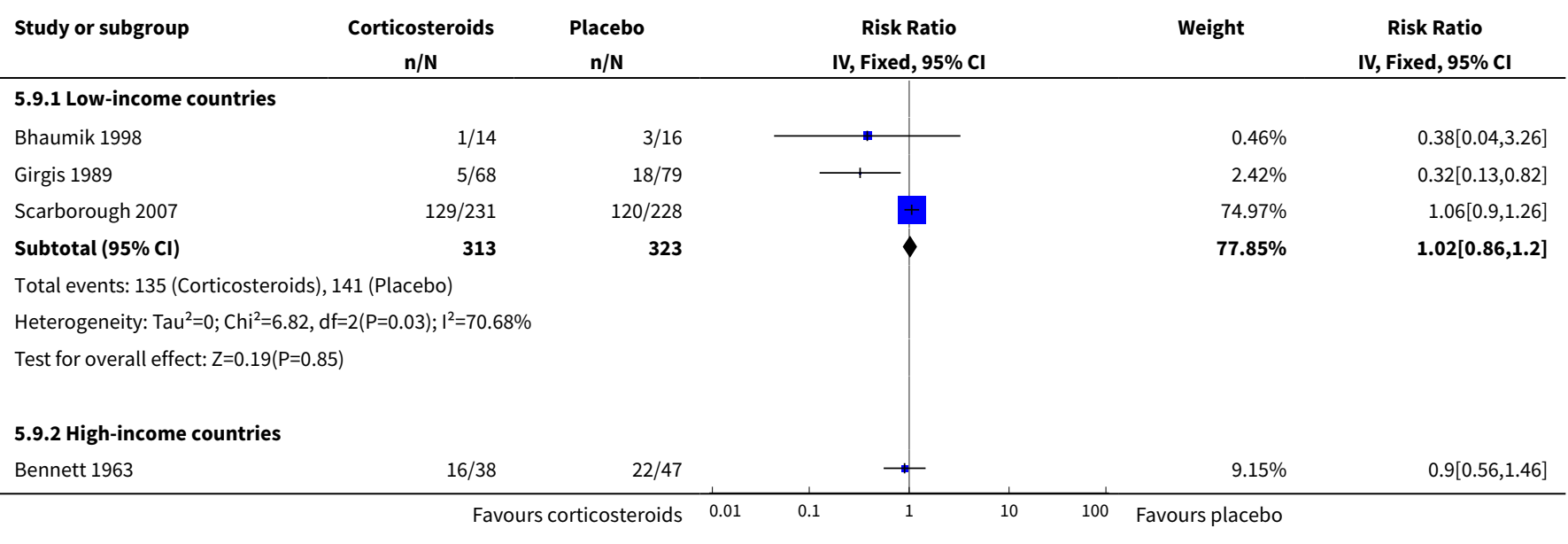




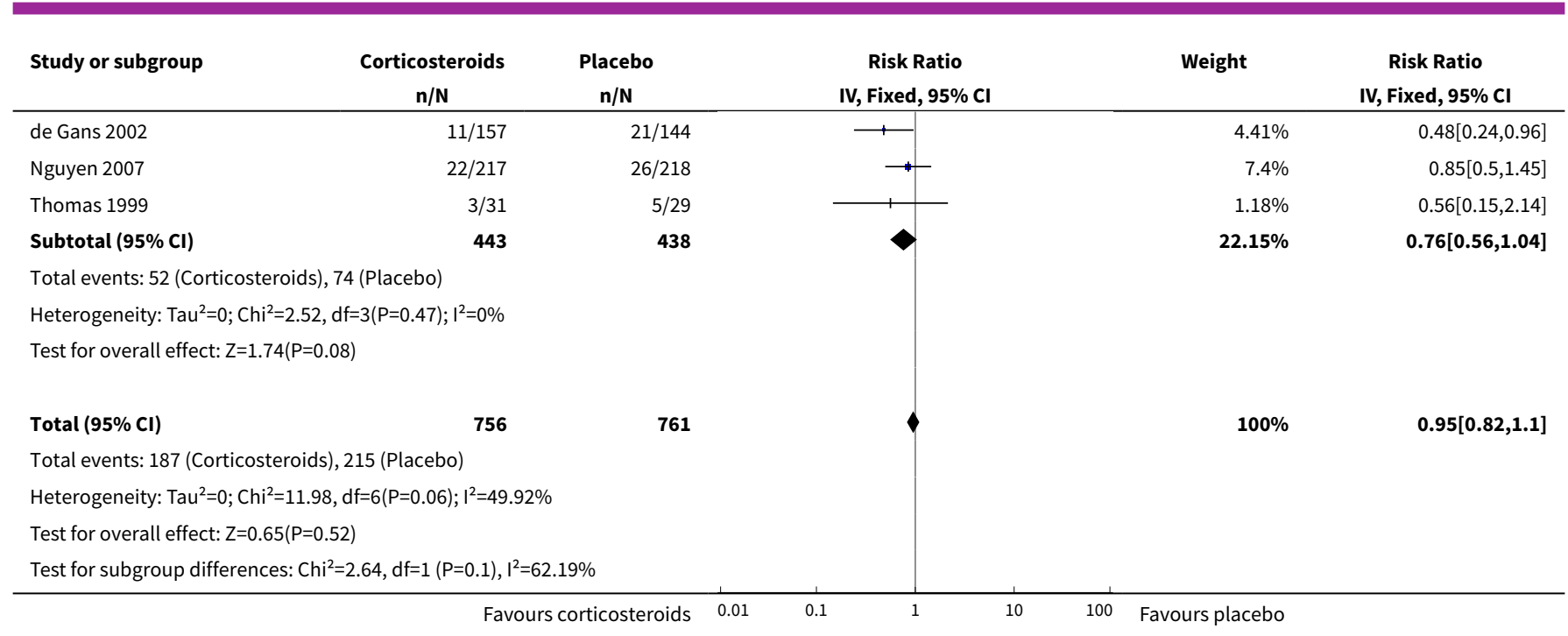

Analysis 5.10. Comparison 5 Income of countries, Outcome 10 Any hearing loss adults.

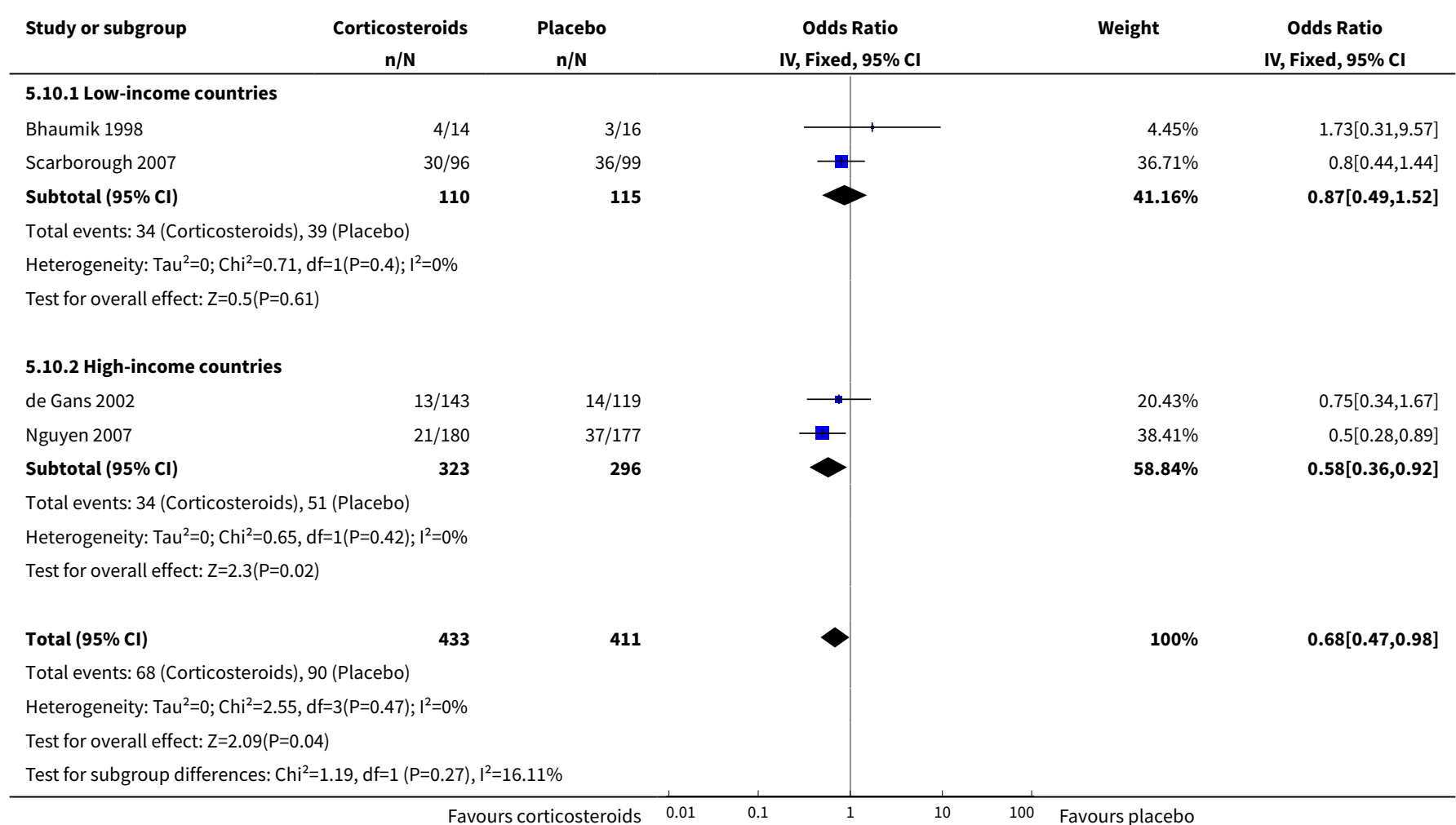


Comparison 6. Timing of steroids

\begin{tabular}{|c|c|c|c|c|}
\hline Outcome or subgroup title & $\begin{array}{l}\text { No. of } \\
\text { studies }\end{array}$ & $\begin{array}{l}\text { No. of } \\
\text { partici- } \\
\text { pants }\end{array}$ & Statistical method & Effect size \\
\hline 1 Mortality & 22 & 3940 & Risk Ratio (IV, Random, 95\% CI) & $0.87[0.73,1.05]$ \\
\hline $\begin{array}{l}1.1 \text { Before or with first dose } \\
\text { antibiotic }\end{array}$ & 13 & 3143 & Risk Ratio (IV, Random, 95\% CI) & $0.87[0.69,1.09]$ \\
\hline 1.2 After first dose antibiotic & 9 & 797 & Risk Ratio (IV, Random, 95\% CI) & $0.83[0.55,1.26]$ \\
\hline 2 Severe hearing loss & 16 & 2300 & Risk Ratio (IV, Fixed, 95\% CI) & $0.82[0.64,1.06]$ \\
\hline $\begin{array}{l}2.1 \text { Before or with first dose } \\
\text { antibiotic }\end{array}$ & 10 & 1866 & Risk Ratio (IV, Fixed, 95\% CI) & $0.81[0.62,1.07]$ \\
\hline 2.2 After first dose antibiotic & 6 & 434 & Risk Ratio (IV, Fixed, 95\% Cl) & $0.89[0.47,1.68]$ \\
\hline 3 Any hearing loss & 18 & 2754 & Risk Ratio (IV, Fixed, 95\% CI) & $0.78[0.68,0.88]$ \\
\hline 3.1 Before or with antibiotics & 12 & 2257 & Risk Ratio (IV, Fixed, 95\% Cl) & $0.80[0.70,0.92]$ \\
\hline $\begin{array}{l}\text { 3.2 After first dose of antibi- } \\
\text { otics }\end{array}$ & 6 & 497 & Risk Ratio (IV, Fixed, 95\% CI) & $0.62[0.43,0.89]$ \\
\hline $\begin{array}{l}4 \text { Short-term neurologic se- } \\
\text { quelae }\end{array}$ & 12 & 1739 & Risk Ratio (IV, Fixed, 95\% CI) & $0.85[0.71,1.03]$ \\
\hline $\begin{array}{l}4.1 \text { Before or with first dose } \\
\text { antibiotic }\end{array}$ & 6 & 1282 & Risk Ratio (IV, Fixed, 95\% Cl) & $0.91[0.73,1.13]$ \\
\hline 4.2 After first dose antibiotic & 6 & 457 & Risk Ratio (IV, Fixed, 95\% CI) & $0.70[0.47,1.04]$ \\
\hline
\end{tabular}

Analysis 6.1. Comparison 6 Timing of steroids, Outcome 1 Mortality.

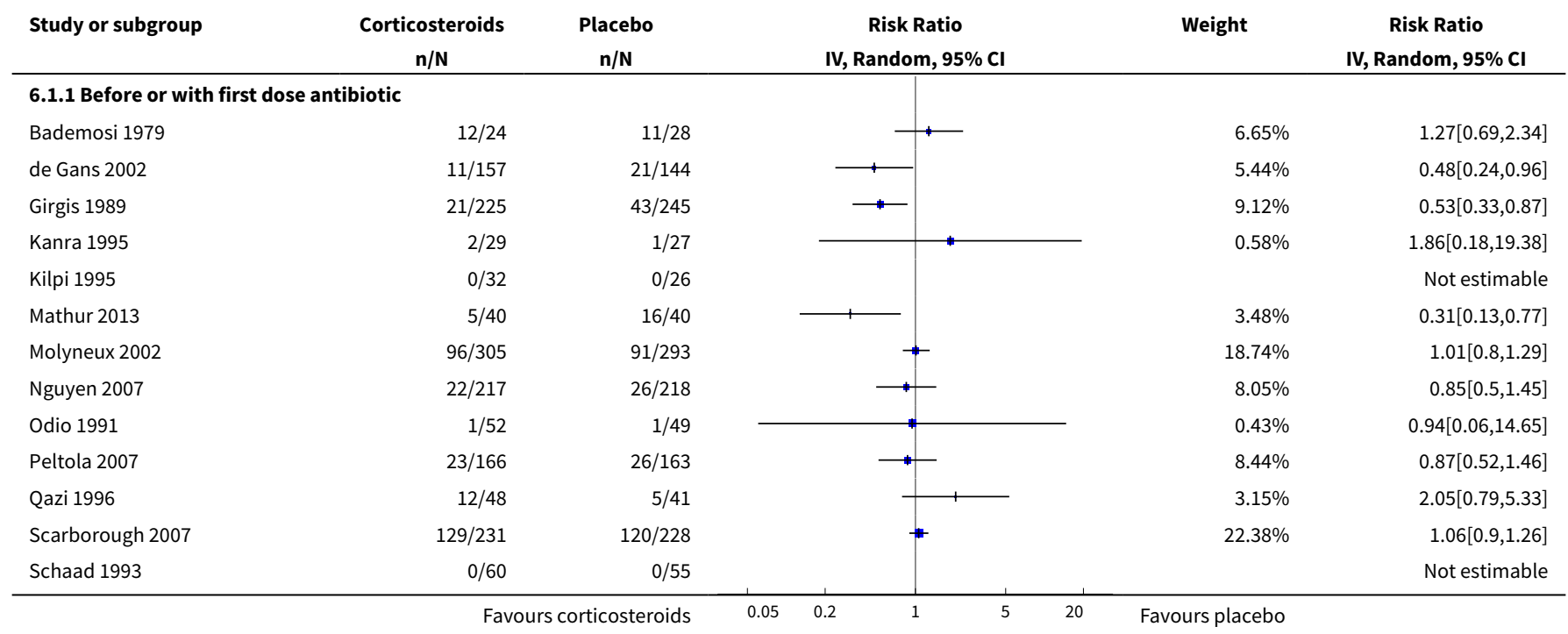




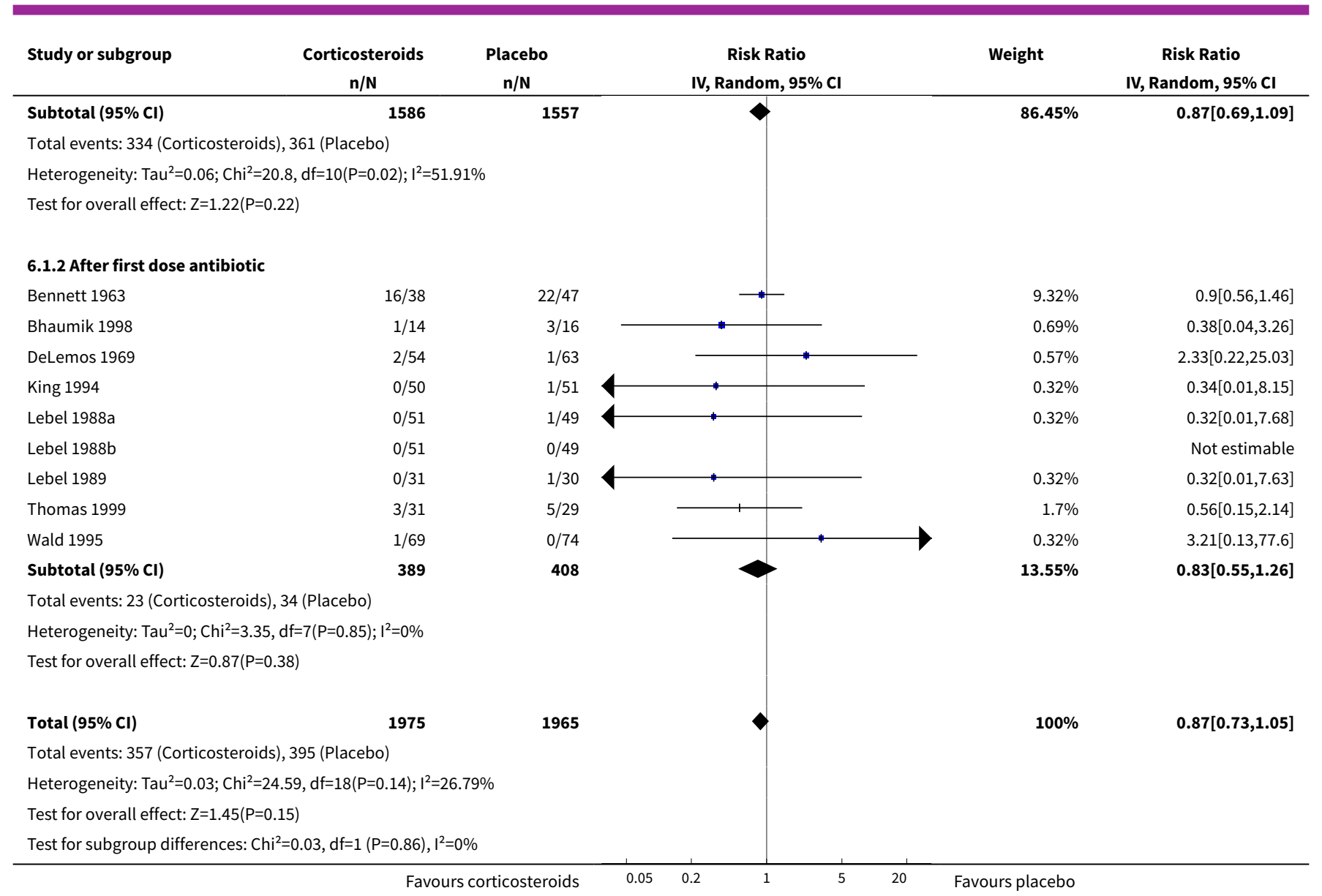

Analysis 6.2. Comparison 6 Timing of steroids, Outcome 2 Severe hearing loss.

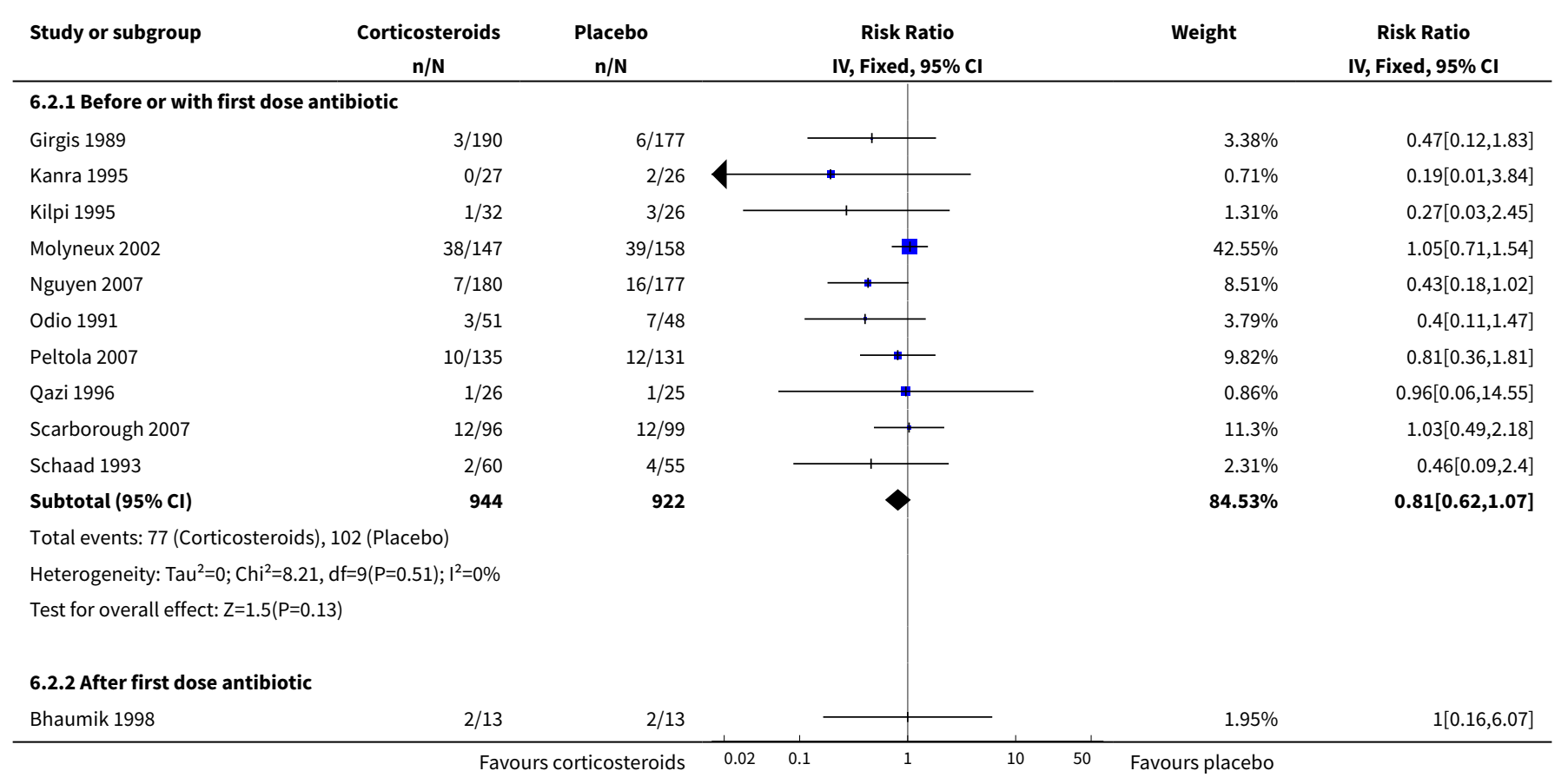




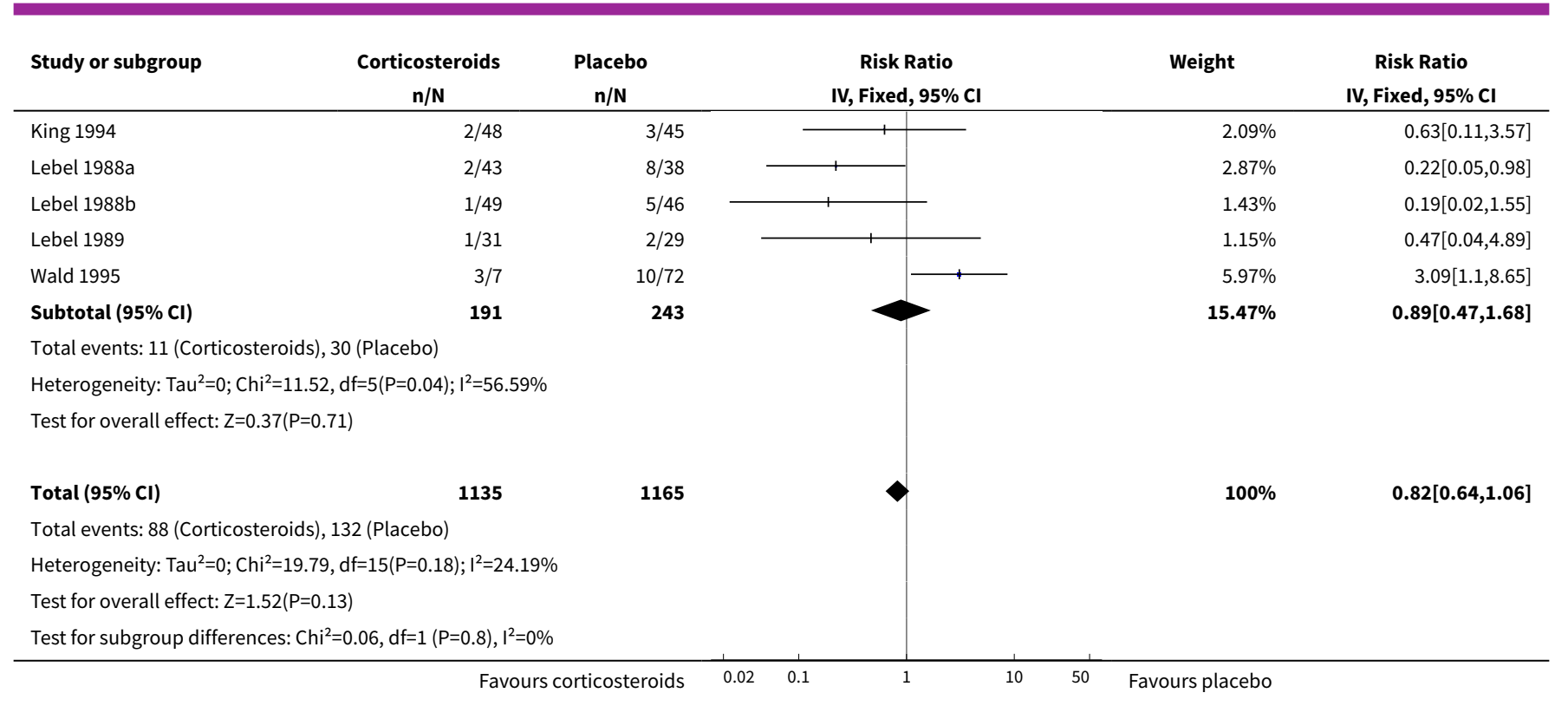

Analysis 6.3. Comparison 6 Timing of steroids, Outcome 3 Any hearing loss.

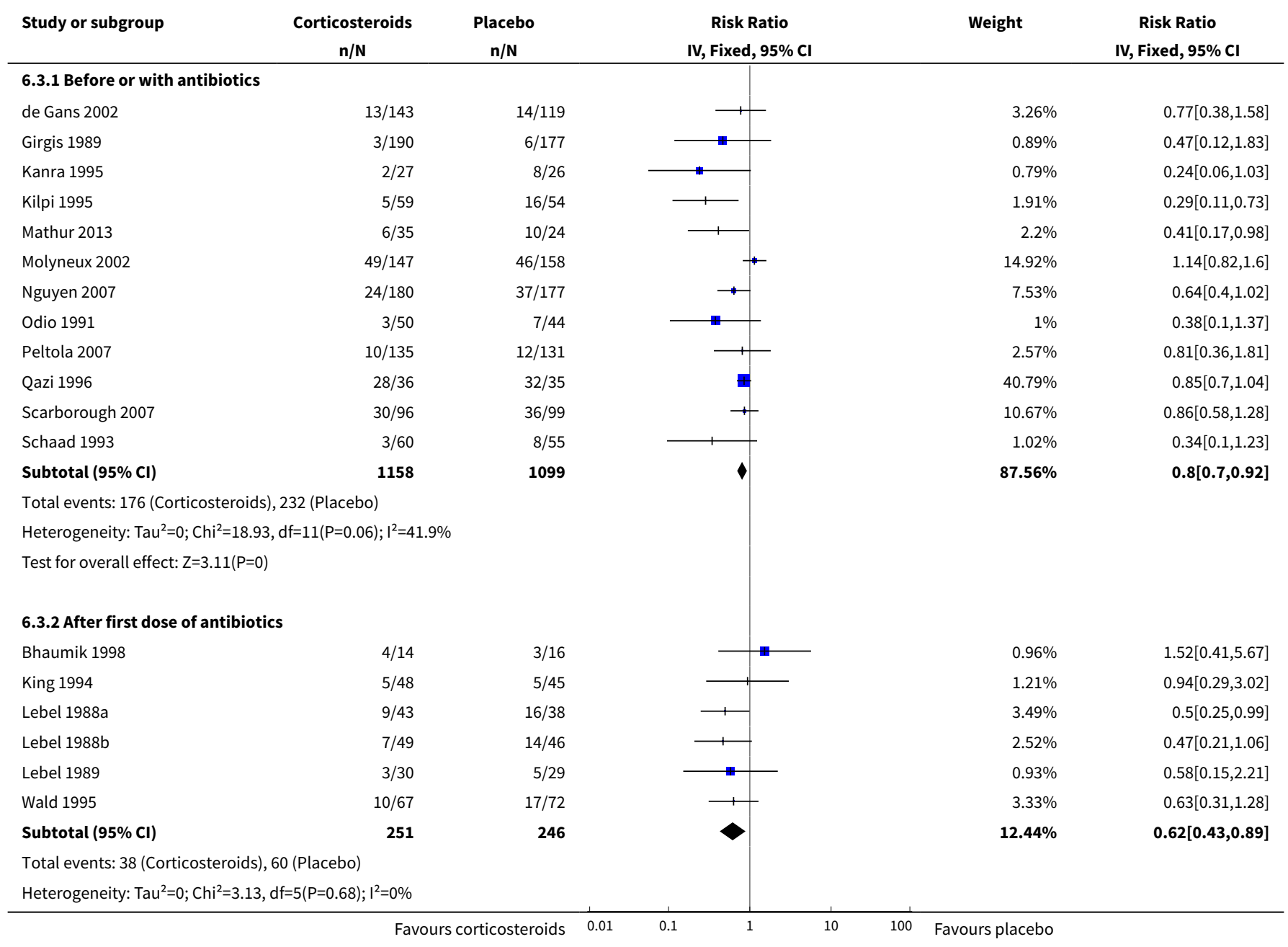




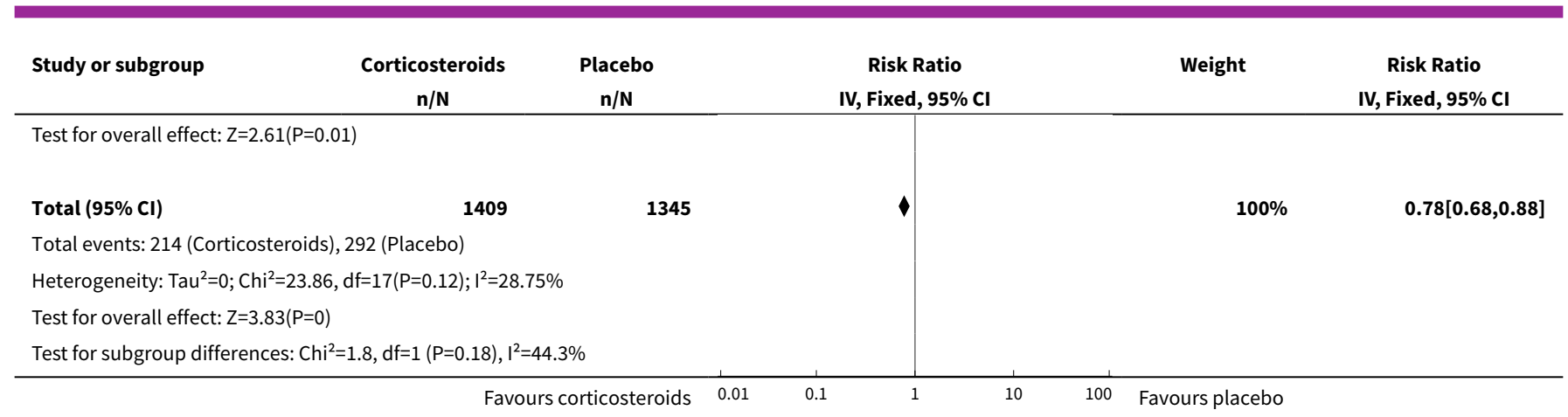

\section{Analysis 6.4. Comparison 6 Timing of steroids, Outcome 4 Short-term neurologic sequelae.}

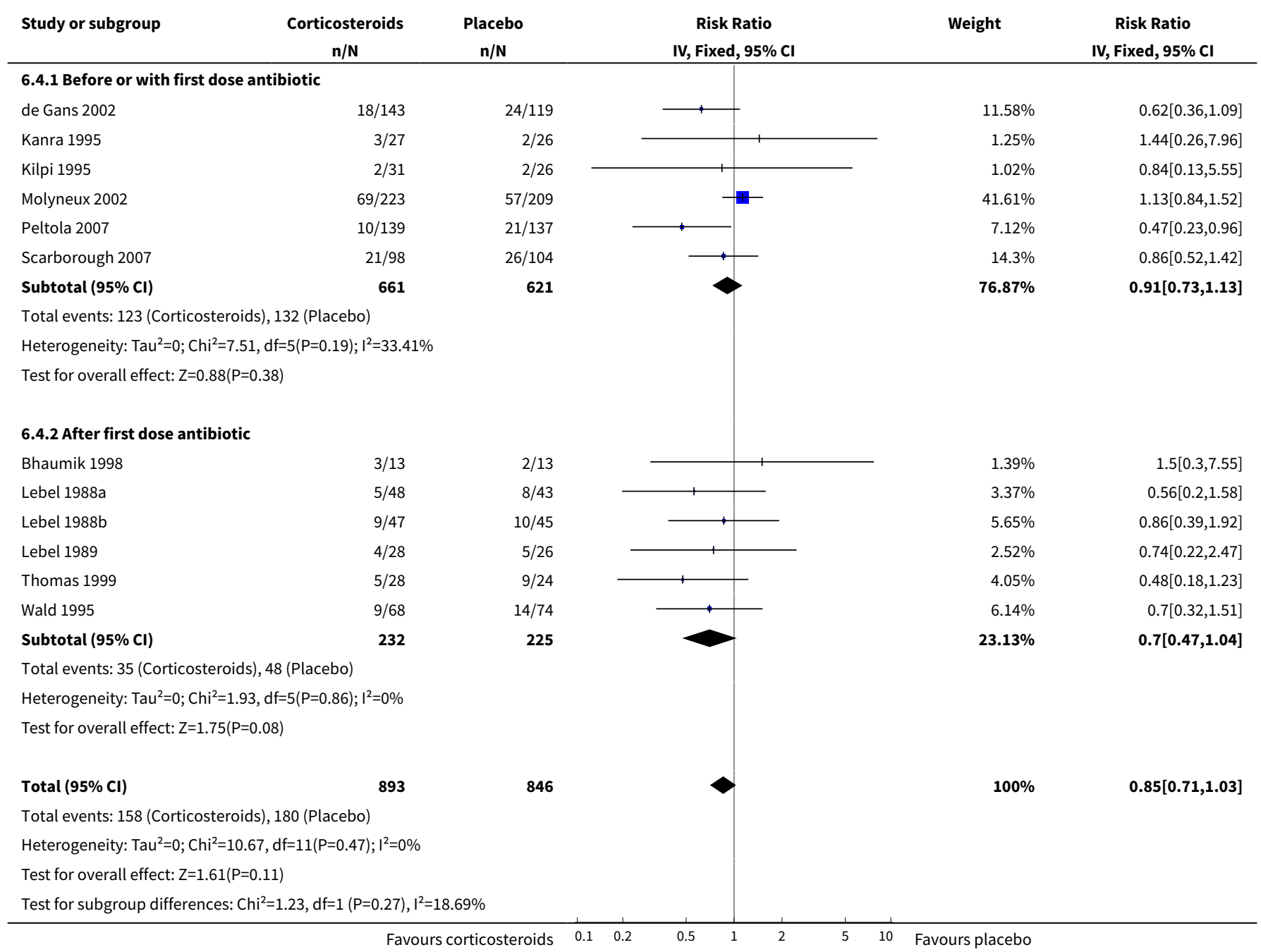


Comparison 7. Study quality

\begin{tabular}{|c|c|c|c|c|}
\hline Outcome or subgroup title & $\begin{array}{l}\text { No. of } \\
\text { studies }\end{array}$ & $\begin{array}{l}\text { No. of } \\
\text { partici- } \\
\text { pants }\end{array}$ & Statistical method & Effect size \\
\hline 1 Mortality & 25 & 4121 & Risk Ratio (IV, Fixed, 95\% CI) & $0.95[0.85,1.06]$ \\
\hline 1.1 High quality & 4 & 1793 & Risk Ratio (IV, Fixed, 95\% CI) & $1.00[0.88,1.14]$ \\
\hline 1.2 Medium quality & 14 & 1477 & Risk Ratio (IV, Fixed, 95\% CI) & $0.81[0.57,1.17]$ \\
\hline 1.3 Low quality & 7 & 851 & Risk Ratio (IV, Fixed, 95\% CI) & $0.79[0.60,1.04]$ \\
\hline 2 Severe hearing loss & 17 & 2442 & Risk Ratio (IV, Fixed, 95\% CI) & $0.72[0.55,0.95]$ \\
\hline 2.1 High quality & 3 & 857 & Risk Ratio (IV, Fixed, 95\% CI) & $0.99[0.69,1.41]$ \\
\hline 2.2 Medium quality & 10 & 1051 & Risk Ratio (IV, Fixed, 95\% CI) & $0.47[0.29,0.75]$ \\
\hline 2.3 Low quality & 4 & 534 & Risk Ratio (IV, Fixed, 95\% CI) & $0.50[0.20,1.29]$ \\
\hline 3 Any hearing loss & 20 & 2806 & Risk Ratio (IV, Fixed, 95\% CI) & $0.79[0.69,0.90]$ \\
\hline 3.1 High quality & 4 & 1119 & Risk Ratio (IV, Fixed, 95\% CI) & $0.90[0.73,1.12]$ \\
\hline 3.2 Medium quality & 12 & 1150 & Risk Ratio (IV, Fixed, 95\% CI) & $0.73[0.62,0.87]$ \\
\hline 3.3 Low quality & 4 & 537 & Risk Ratio (IV, Fixed, 95\% CI) & $0.76[0.38,1.51]$ \\
\hline $\begin{array}{l}4 \text { Short-term neurological se- } \\
\text { quelae }\end{array}$ & 13 & 1756 & Risk Ratio (IV, Fixed, 95\% CI) & $0.85[0.70,1.03]$ \\
\hline 4.1 High quality & 3 & 896 & Risk Ratio (IV, Fixed, 95\% CI) & $0.97[0.77,1.23]$ \\
\hline 4.2 Medium quality & 8 & 784 & Risk Ratio (IV, Fixed, 95\% CI) & $0.63[0.45,0.89]$ \\
\hline 4.3 Low quality & 2 & 76 & Risk Ratio (IV, Fixed, 95\% CI) & $0.83[0.35,1.95]$ \\
\hline
\end{tabular}

Analysis 7.1. Comparison 7 Study quality, Outcome 1 Mortality.

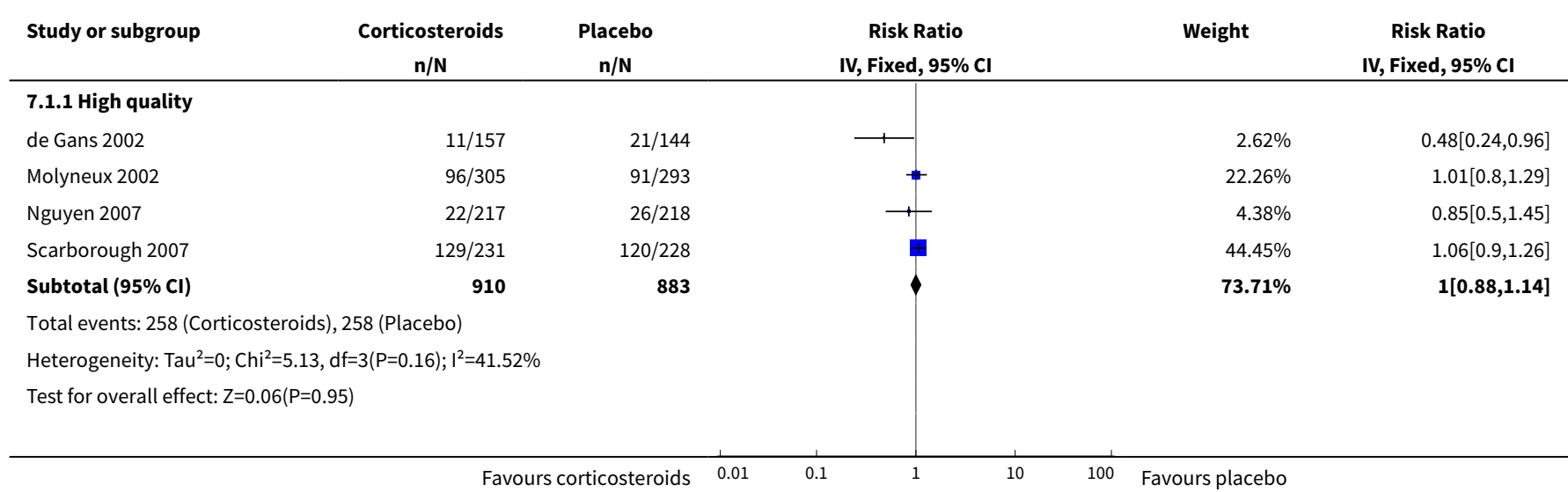




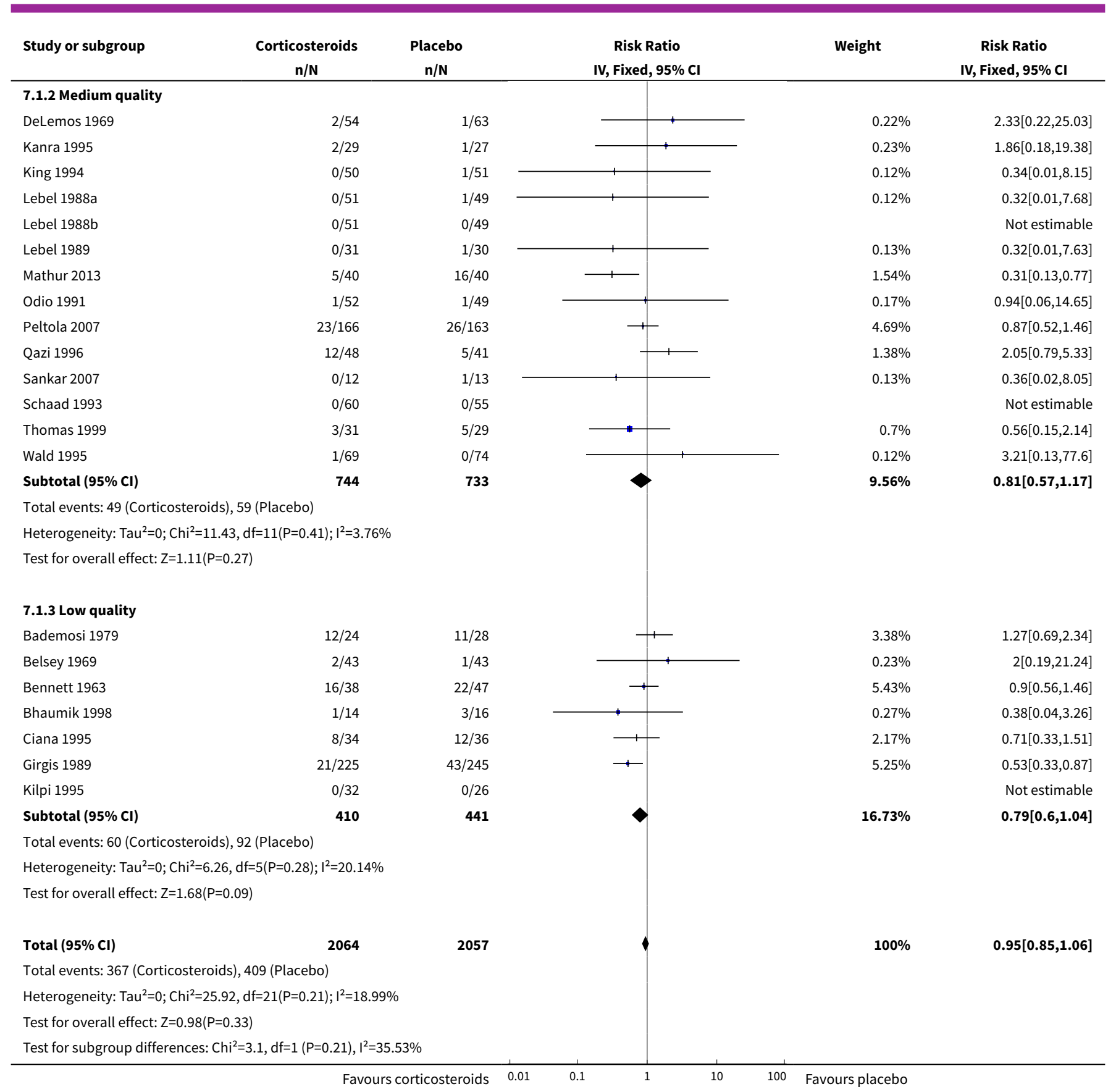

Analysis 7.2. Comparison 7 Study quality, Outcome 2 Severe hearing loss.

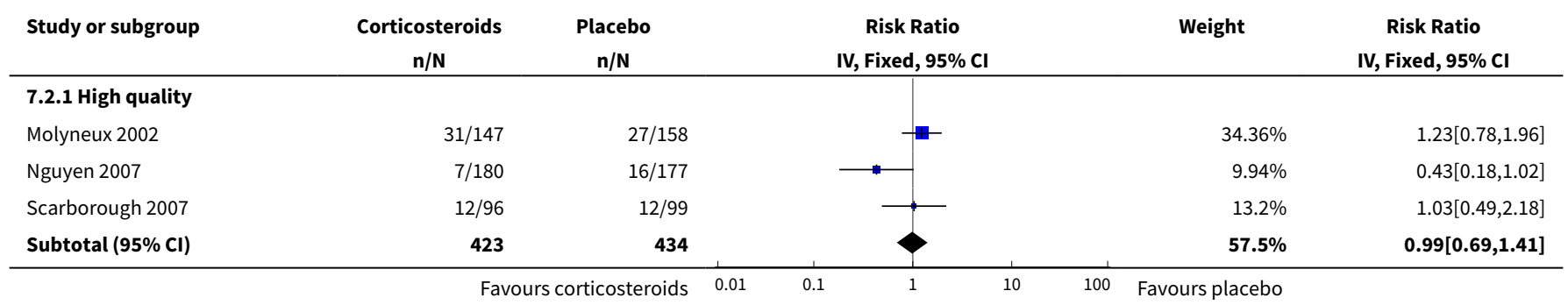




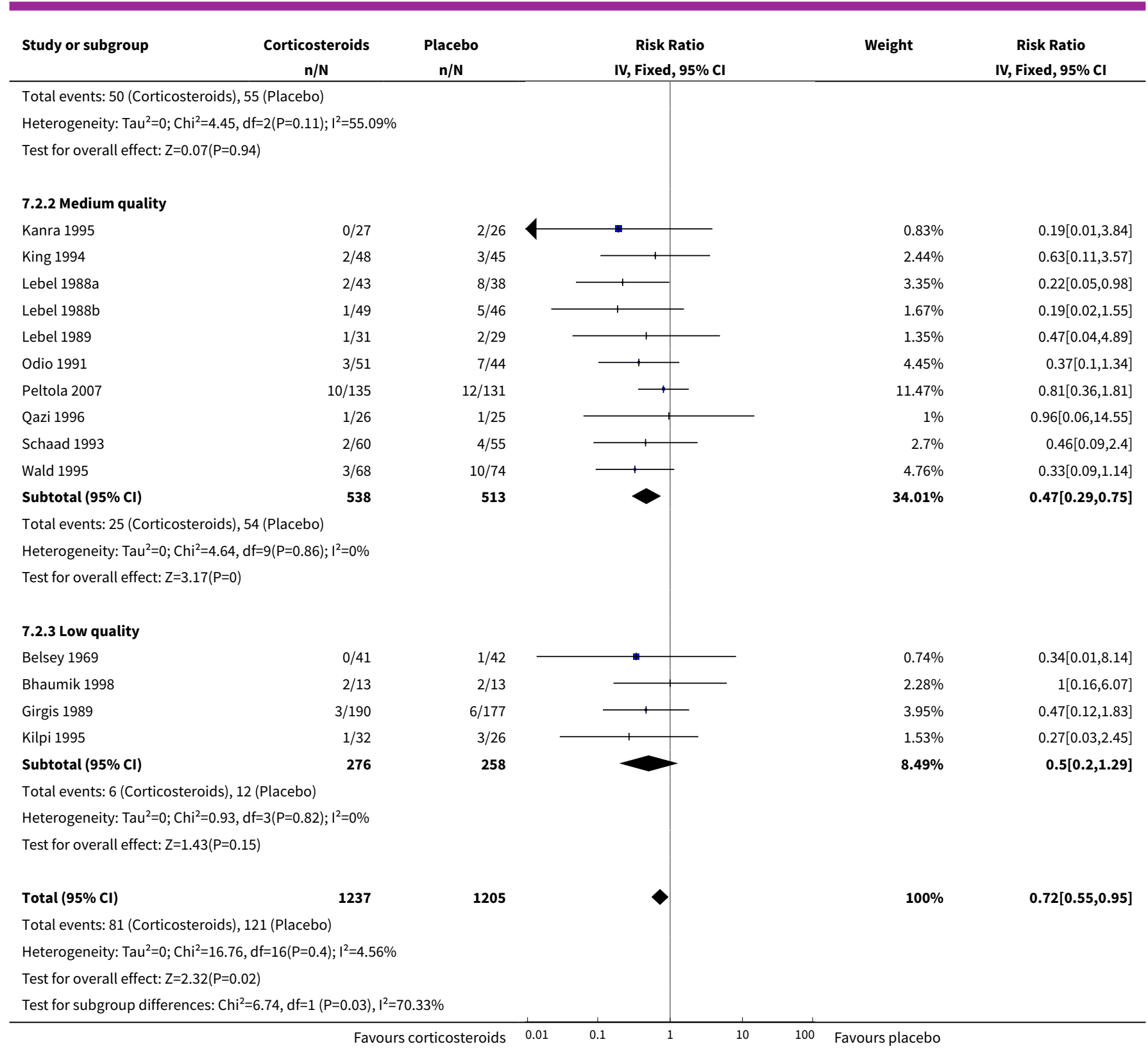

Analysis 7.3. Comparison 7 Study quality, Outcome 3 Any hearing loss.

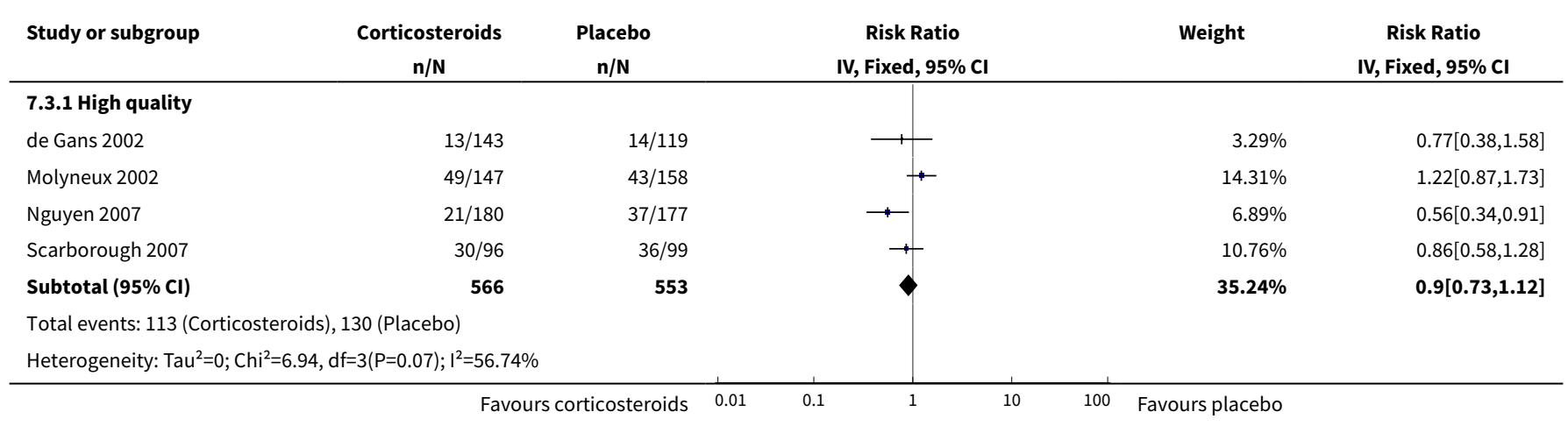




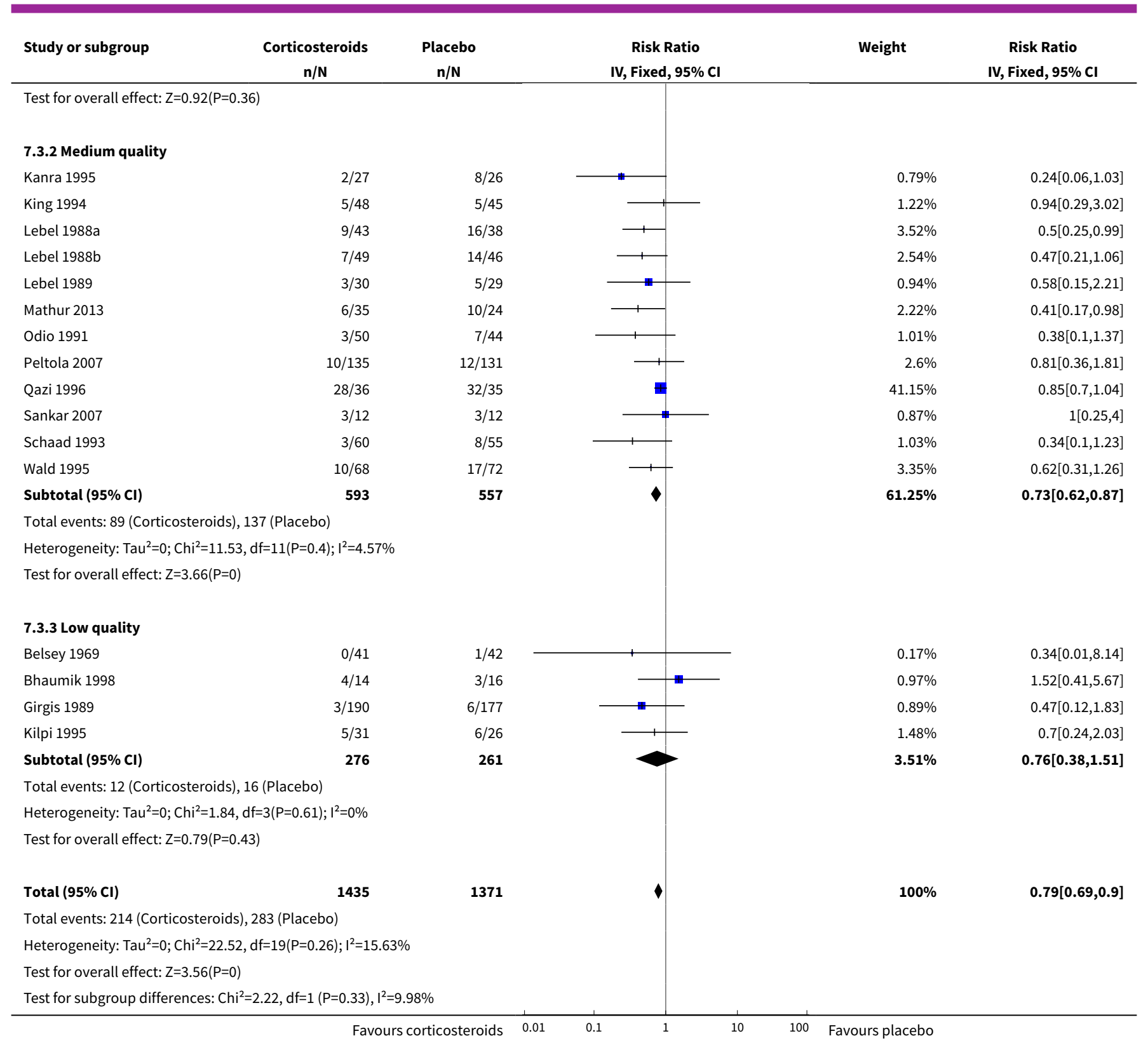

\section{Analysis 7.4. Comparison 7 Study quality, Outcome 4 Short-term neurological sequelae.}

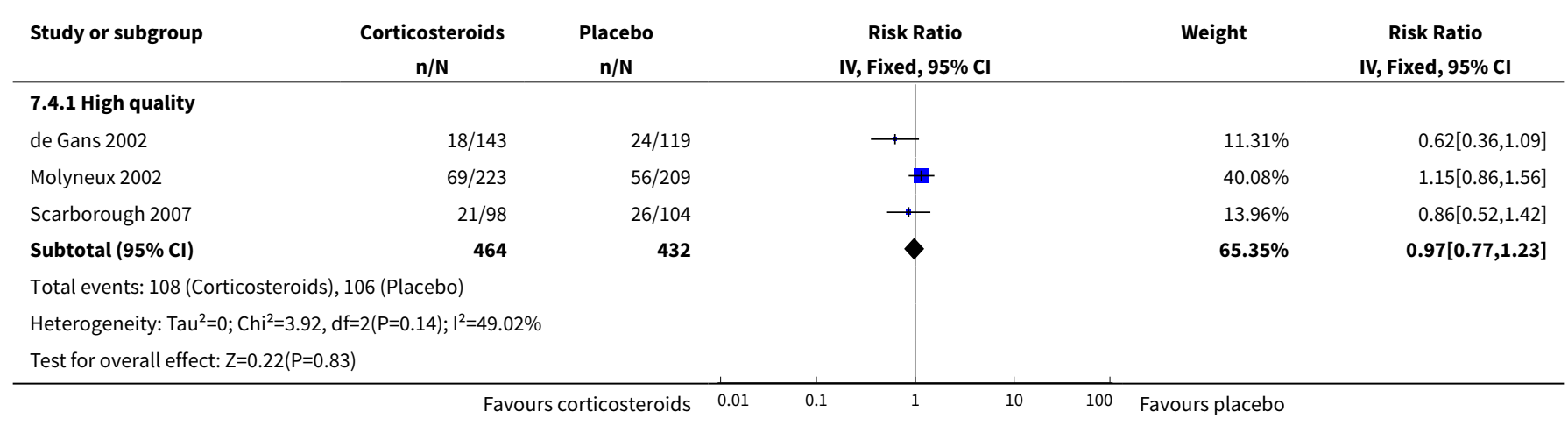




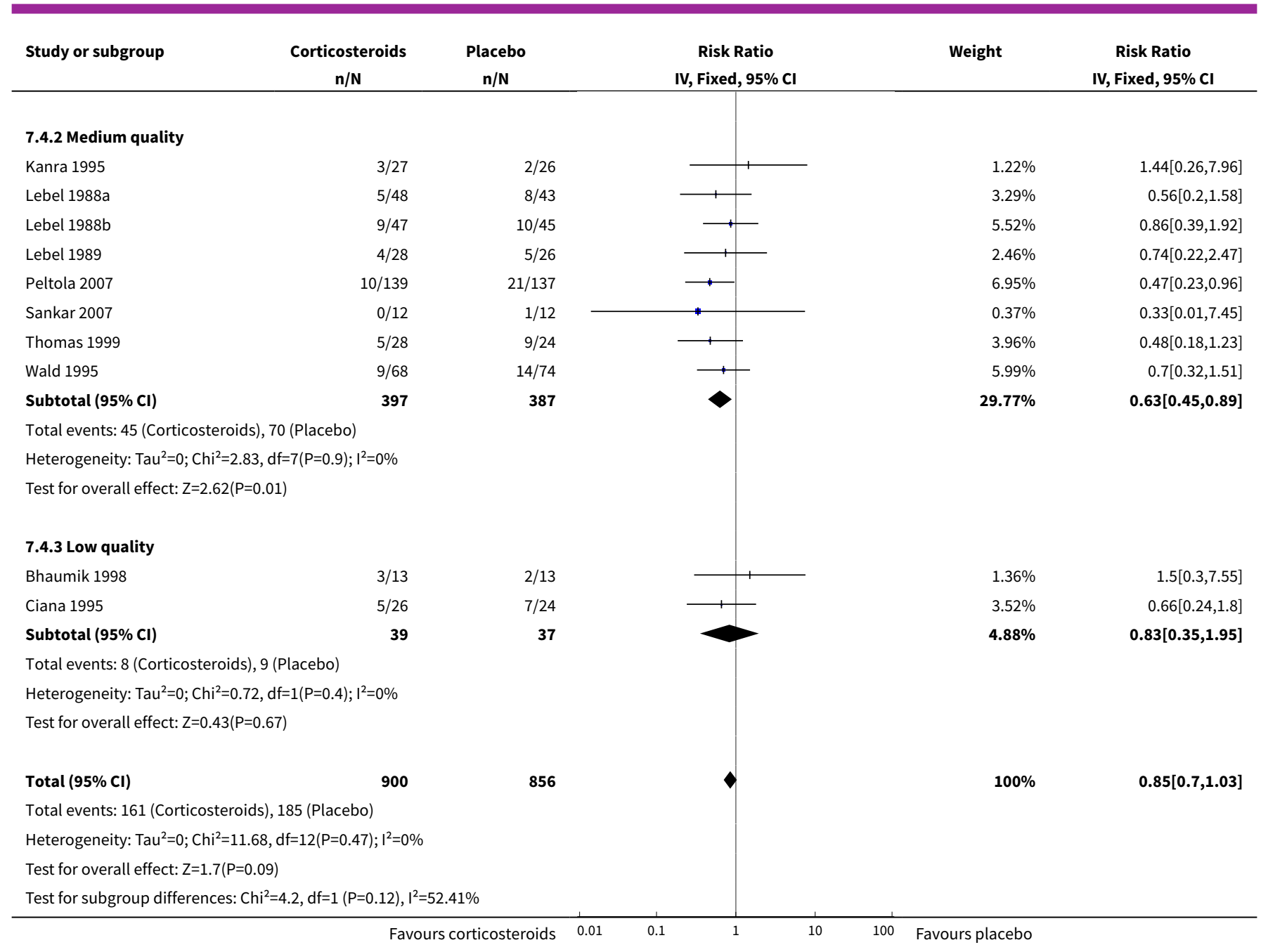

Comparison 8. Sensitivity analysis - worst-case scenario

\begin{tabular}{lllll}
\hline Outcome or subgroup title & $\begin{array}{l}\text { No. of } \\
\text { studies }\end{array}$ & $\begin{array}{l}\text { No. of } \\
\text { partici- } \\
\text { pants }\end{array}$ & Statistical method & Effect size \\
\hline 1 Severe hearing loss & 17 & 2694 & Risk Ratio (M-H, Random, 95\% Cl) & $1.25[0.81,1.93]$ \\
\hline 2 Any hearing loss & 20 & 3029 & Risk Ratio (M-H, Random, 95\% Cl) & $0.98[0.71,1.35]$ \\
\hline 3 Short-term neurological sequelae & 13 & 1850 & Risk Ratio (M-H, Fixed, 95\% Cl) & $0.98[0.82,1.18]$ \\
\hline 4 Long-term neurological sequelae & 13 & 1758 & Risk Ratio (M-H, Random, 95\% Cl) & $1.18[0.78,1.78]$ \\
\hline
\end{tabular}


Analysis 8.1. Comparison 8 Sensitivity analysis - worst-case scenario, Outcome 1 Severe hearing loss.

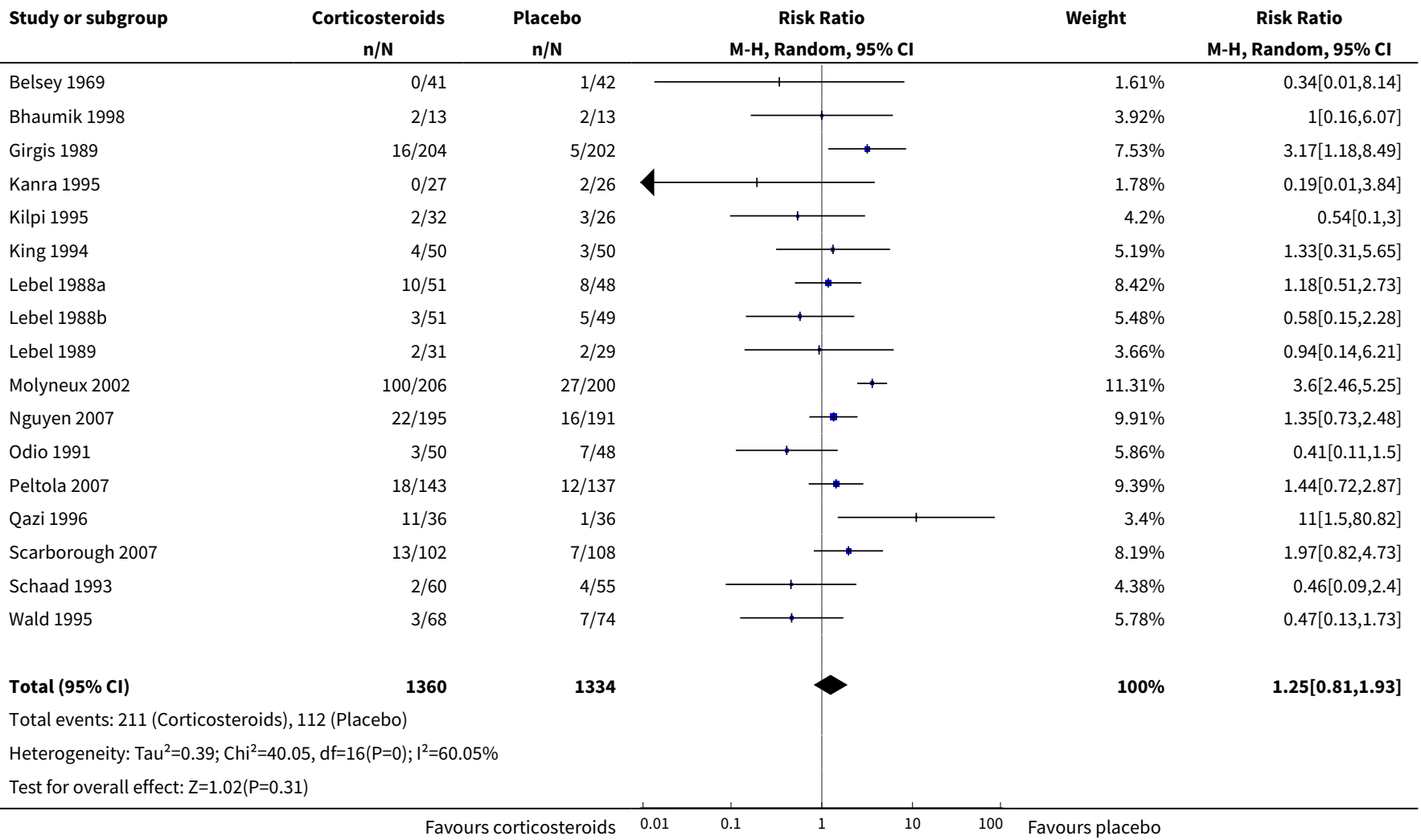

Analysis 8.2. Comparison 8 Sensitivity analysis - worst-case scenario, Outcome 2 Any hearing loss.

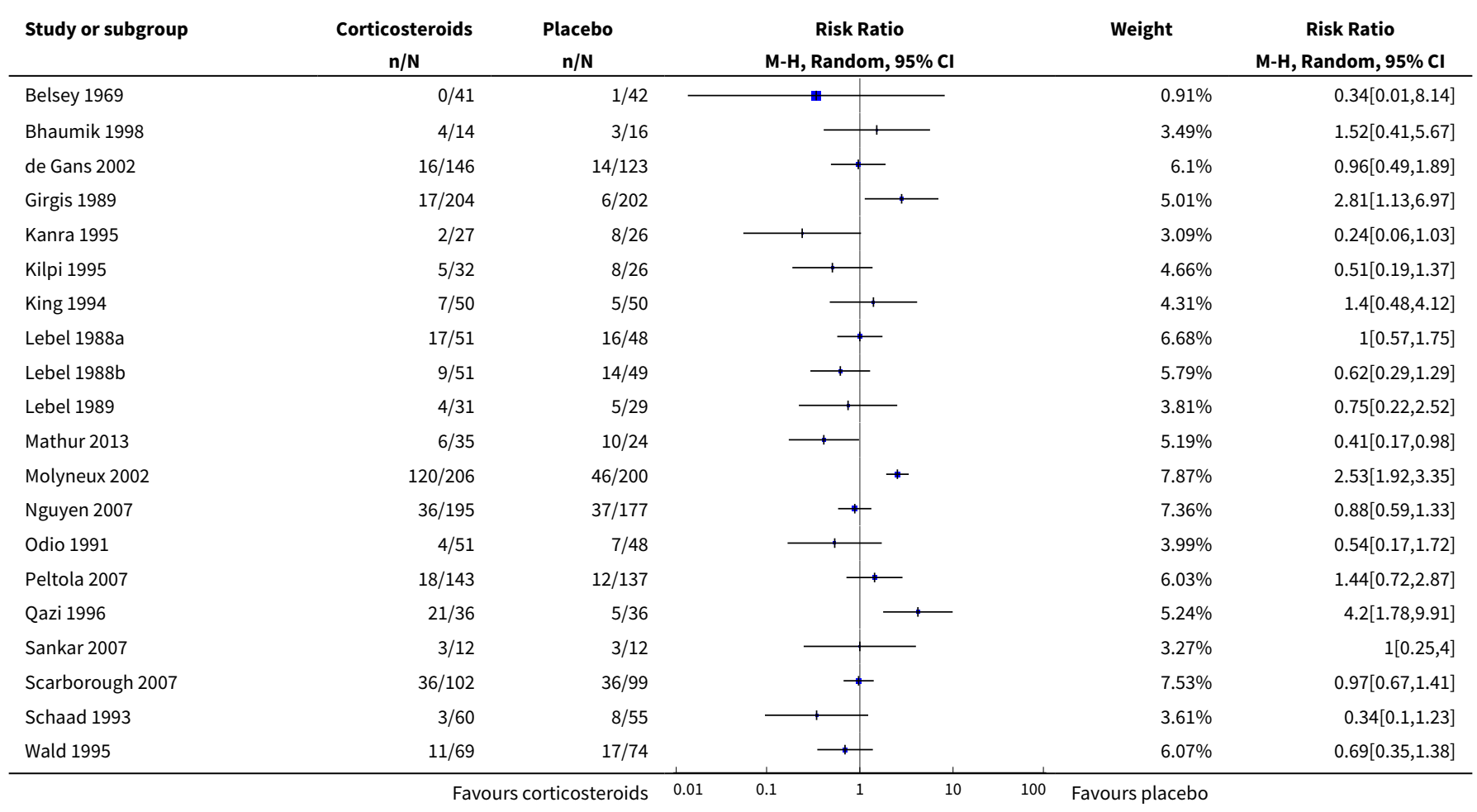




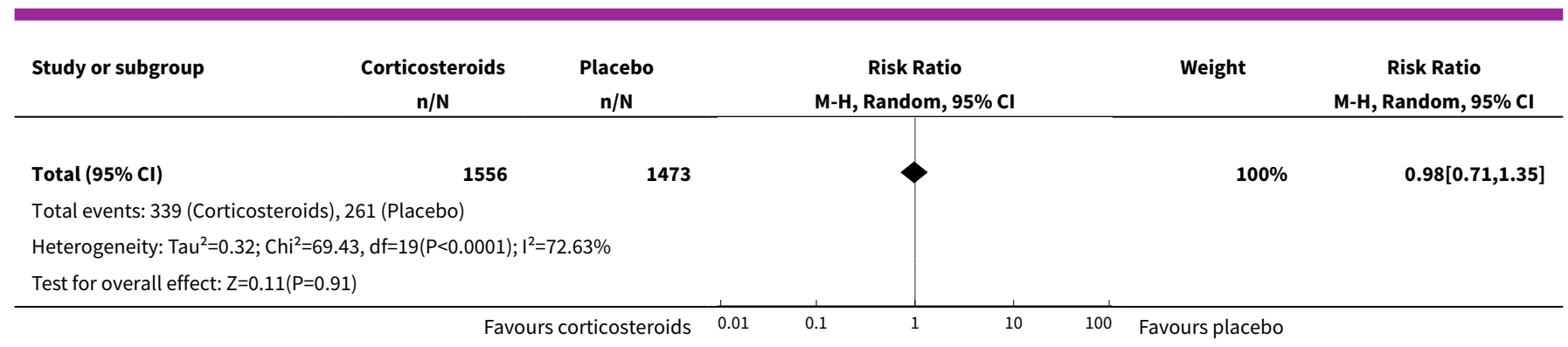

Analysis 8.3. Comparison 8 Sensitivity analysis - worst-case scenario, Outcome 3 Short-term neurological sequelae.

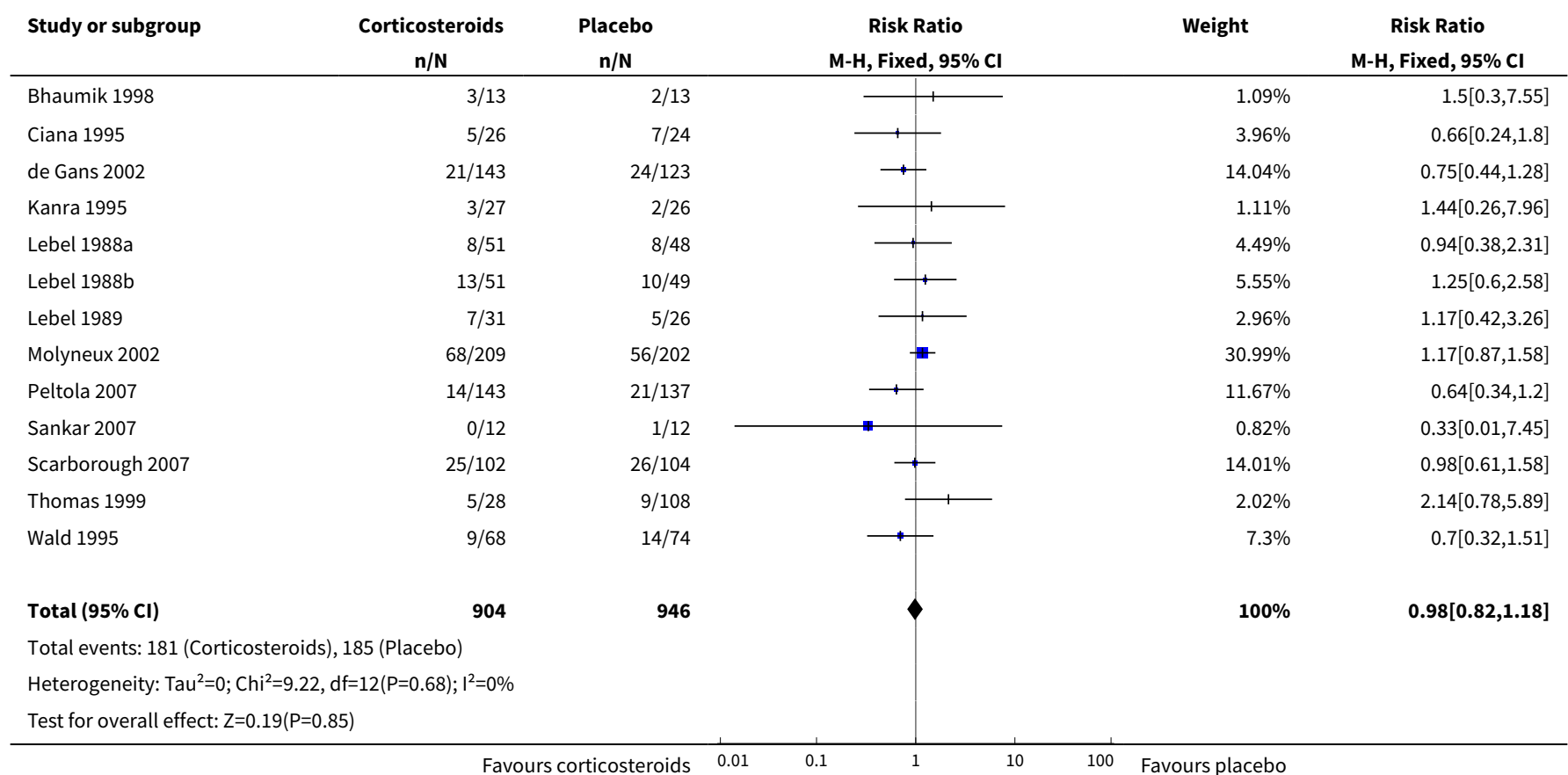

Analysis 8.4. Comparison 8 Sensitivity analysis - worst-case scenario, Outcome 4 Long-term neurological sequelae.

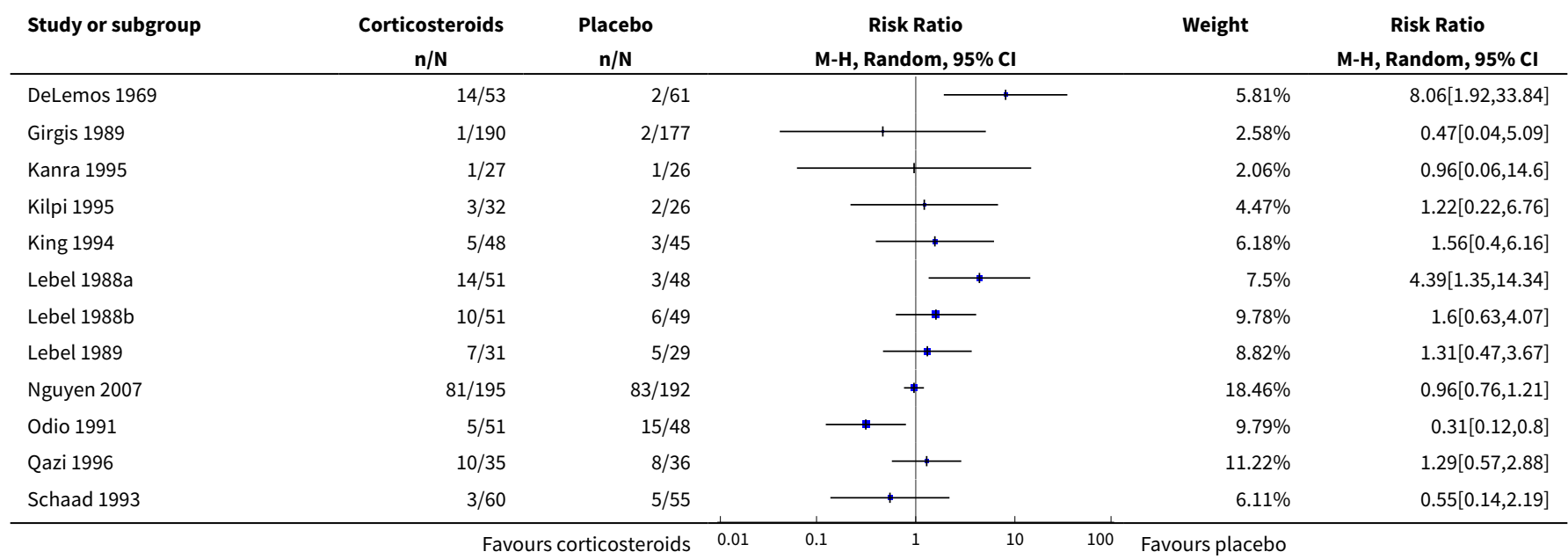




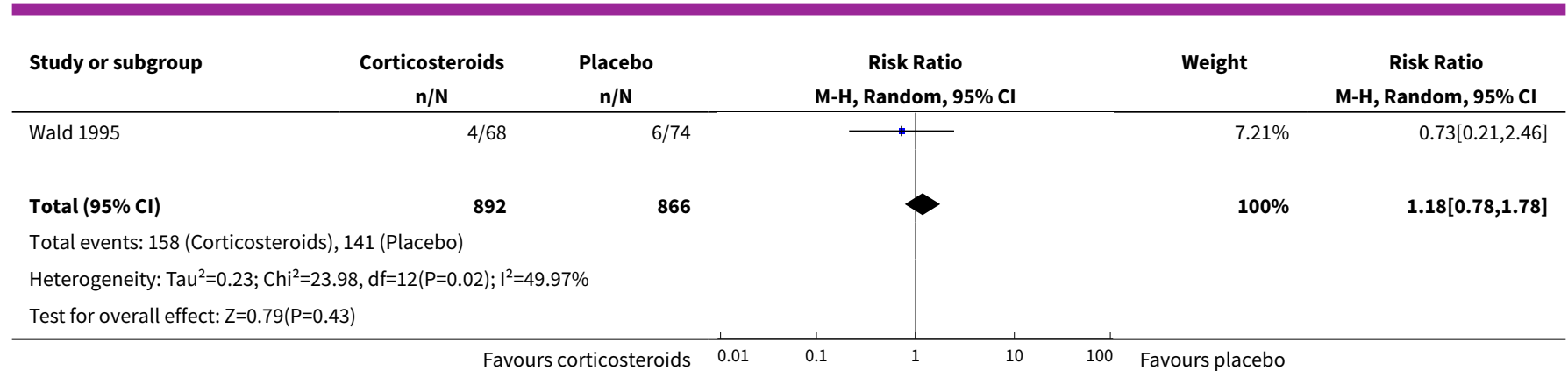

\section{APPENDICES}

\section{Appendix 1. Glossary of terms}

Adjuvant therapy - medication given in addition to primary therapy (for bacterial meningitis primary therapy consist of antibiotics). Low-income countries - countries with a UN human development index below 0.7 (58 of 182 countries in 2009).

High-income countries - countries with a UN human development index over 0.7 .

\section{Appendix 2. Details of previous searches}

In the first publication of this review, we searched the Cochrane Central Register of Controlled Trials (CENTRAL) (The Cochrane Library 2003, Issue 1), which includes the Cochrane Acute Respiratory Infections Group Specialised Register, MEDLINE (1966 to April 2002), EMBASE (1974 to April 2002), HEALTHLINE (1988 to April 2002), Current Contents for trials published before 1 April 2002 and reference lists of all articles. We also contacted manufacturers and researchers in the field (DvdB).

In the 2006 update, we searched the Cochrane Central Register of Controlled Trials (CENTRAL) (The Cochrane Library 2006, Issue 2), MEDLINE (1966 to July 2006), EMBASE (1974 to June 2006) and Current Contents (2001 to June 2006).

In the 2010 update we searched the Cochrane Central Register of Controlled Trials (CENTRAL) (The Cochrane Library 2010, Issue 1), MEDLINE (1966 to February 2010), EMBASE (1974 to February 2010), Current Contents (2001 to February 2010) and Web of Science, restricting search results to years published 2006 to 2009.

In the 2012 update we searched the Cochrane Central Register of Controlled Trials (CENTRAL) (The Cochrane Library 2012, Issue 11), MEDLINE (1966 to July 2012), EMBASE (1974 to July 2012), Current Contents (2001 to July 2012) and Web of Science, restricting search results to years published 2009 to 2012.

MEDLINE was searched using keywords and MeSH terms below in conjunction with the highly sensitive search strategy designed by The Cochrane Collaboration for identifying RCTs (Higgins 2011). The same strategy was used to search CENTRAL and adapted to search EMBASE (WebSpirs) and Current Contents (OVID).

We performed the search without any language or publication restrictions.

1 exp Meningitis/

2 meningit $^{*}: a b, t i$

3 or $/ 1-2$

4 exp 'corticosteroid'/

5 'adrenal cortex hormones':ab,ti

6 'adrenal cortex hormone':ab,ti

7 corticosteroid ${ }^{*}: a b, t i$

8 dexameth*:ab,ti

9 exp 'dexamethasone'/

10 steroid $^{\star}: a b$,ti

11 exp 'steroid'

12 or/ 4-11

133 and 11

For the 2013 update we searched, as in previous years, the Cochrane Central Register of Controlled Trials (CENTRAL 2012, Issue 12) (accessed 18 January 2013), which includes the Cochrane Acute Respiratory Infections Group Specialised Register, MEDLINE (January 2010 
to January Week 2, 2013), EMBASE (February 2010 to January 2013) and Web of Science (2010 to January 2013). In addition, in order to cover more of the published literature, we broadened our search to include CINAHL (2010 to January 2013) and LILACS (2010 to January 2013).

\section{Appendix 3. MEDLINE (Ovid) search strategy}

1 exp Meningitis/

2 meningit*.tw.

3 exp Neisseria meningitidis/

4 exp Haemophilus influenzae/

5 Streptococcus pneumoniae/

6 ("N. meningitidis" or "H. influenzae" or "S. pneumoniae").tw.

7 ("neisseria meningitidis" or "haemophilus influenzae" or "streptococcus pneumoniae").tw.

8 or/1-7

9 exp Adrenal Cortex Hormones/

10 corticosteroid $^{*} . t w, n m$.

11 glucocorticoid ${ }^{\star}$. tw, nm.

12 exp Steroids/

13 steroid $^{*} . \mathrm{tw}, \mathrm{nm}$.

14 exp Dexamethasone/

15 (dexamethasone $e^{\star}$ or hydrocortisone* or prednisolone* or methylprednisolone ${ }^{\star}$ ).tw,nm.

16 or/9-15

178 and 16

\section{Appendix 4. EMBASE.com search strategy}

\#21 \#6 AND \#12 AND \#20

\#20 \#19 NOT \#18

\#19 \#13 OR \#14

\#18 \#15 NOT \#17

\#17 \#15 AND \#16

\#16 'human'/de

\#15 'nonhuman'/de OR 'animal'/de OR 'animal experiment'/de

\#14 random*:ab,ti OR placebo*:ab,ti OR crossover*ab,ti OR 'cross over':ab,ti OR allocat*ab,ti OR trial:ti OR (doubl* NEXT/1 blind*):ab,ti

$\# 13$ 'randomized controlled trial'/exp OR 'single blind procedure'/exp OR 'double blind procedure'/exp OR 'crossover procedure'/exp

\#12 \#7 OR \#8 OR \#9 OR \#10 OR \#11

\#11 dexamethasone*:ab,ti OR hydrocortisone*:ab,ti OR prednisolone*:ab,ti OR methylprednisolone*:ab,ti

\#10 steroid*:ab,ti

\#9 'steroid'/exp

\#8 corticosteroid ${ }^{\star}:$ ab,ti OR glucocorticoid* ${ }^{*}$ ab,ti

$\# 7$ 'corticosteroid'/exp

\#6 \#1 OR \#2 OR \#3 OR \#4 OR \#5

\#5 'neisseria meningitidis':ab,ti OR 'haemophilus influenzae':ab,ti OR 'streptococcus pneumoniae':ab,ti

\#4 'n. meningitidis':ab,ti OR 'h. influenzae':ab,ti OR 's. pneumoniae':ab,ti

\#3 'neisseria meningitidis'/de OR 'haemophilus influenzae'/exp OR 'streptococcus pneumoniae'/de

\#2 meningit*:ab,ti

\#1 'meningitis'/exp

\section{Appendix 5. Web of Science (Thomson Reuters) search strategy}

\begin{tabular}{|l|l|}
\hline$\# 3$ & 32 \\
\hline$\# 2$ & \\
\hline & 217,233 \\
\hline$\# 1$ & 263 \\
\hline
\end{tabular}




\section{Appendix 6. CINAHL (Ebsco) search strategy}

S25 S14 and S24

$\mathrm{S} 24 \mathrm{~S} 15$ or S16 or S17 or S18 or S19 or S20 or S21 or S22 or S23

S23 (MH "Random Assignment")

S22 (MH "Quantitative Studies")

S21 TI placebo* OR AB placebo*

S20 (MH "Placebos")

S19 TI random* OR AB random*

S18 TI ((singl* or doubl ${ }^{\star}$ or tripl* or trebl*) W1 (blind ${ }^{\star}$ or mask $\left.\left.{ }^{\star}\right)\right)$ OR AB ((singl* or doubl* or tripl* or trebl*) W1 (blind ${ }^{\star}$ or mask $\left.\left.^{\star}\right)\right)$

S17 TI clinic trial $^{\star}$ OR AB clinic $^{\star}$ trial $^{\star}$

S16 PT clinical trial

S15 (MH "Clinical Trials+")

S14 S6 and S13

$\mathrm{S} 13 \mathrm{~S} 7$ or $\mathrm{S} 8$ or $\mathrm{S} 9$ or $\mathrm{S} 10$ or $\mathrm{S} 11$ or $\mathrm{S} 12$

S12 TI (dexamethasone* or hydrocortisone* or prednisolone* or methylprednisolone ${ }^{\star}$ ) OR AB (dexamethasone ${ }^{\star}$ or hydrocortisone ${ }^{\star}$ or prednisolone* or methylprednisolone*)

S11 TI steroid* OR AB steroid*

S10 (MH "Steroids+")

S9 TI glucocorticoid* OR AB glucocorticoid*

S8 TI corticosteroid* OR AB corticosteroid*

S7 (MH "Adrenal Cortex Hormones+")

$\mathrm{S} 6 \mathrm{~S} 1$ or $\mathrm{S} 2$ or $\mathrm{S} 3$ or $\mathrm{S} 4$ or $\mathrm{S} 5$

S5 TI ("neisseria meningitidis" or "haemophilus influenzae" or "streptococcus pneumoniae") OR AB ("neisseria meningitidis" or "haemophilus influenzae" or "streptococcus pneumoniae")

S4 TI ("N. meningitidis" or "H. influenzae" or "S. pneumoniae") OR AB ("N. meningitidis" or "H. influenzae" or "S. pneumoniae")

S3 (MH "Haemophilus Influenzae")

S2 TI meningit* OR AB meningit*

$\mathrm{S} 1$ (MH "Meningitis+")

\section{Appendix 7. LILACS (Bireme) search strategy}

$>$ Search > (MH:meningitis OR meningit\$ MH:C10.228.228.507\$ OR MH:C10.228.566\$ OR MH:"Neisseria meningitidis" OR MH:B03.440.400.425.550.550.641\$ OR B03.660.075.525.520.500\$ OR MH:"Haemophilus influenzae" OR MH:B03.440.450.600.450.330\$ OR MH:B03.660.250.550.290.330\$ OR MH:"Streptococcus pneumoniae" OR "N. meningitidis" OR "H. influenzae" OR "S. pneumoniae" OR "neisseria meningitidis" or "haemophilus influenzae" or "streptococcus pneumoniae") AND (MH:"Adrenal Cortex Hormones" OR corticosteroid\$ OR Corticoesteroides OR Corticosteróides OR Corticoids OR MH:D06.472.040\$ OR MH:glucocorticoids OR glucocorticoid \$ OR Glucocorticoides OR Glucocorticóides OR Glicocorticoides OR MH:steroids OR Esteroides OR Esteróides OR MH:D04.808\$ OR MH:Dexamethasone OR Dexametasona OR Hexadecadrol OR Hydrocortisone OR Hidrocortisona OR Cortisol OR MH:methylprednisolone OR Metilprednisolona OR MH:prednisolone OR prednisolon\$) > clinical_trials

\section{FEE D B A C K}

\section{Corticosteroids for acute bacterial meningitis, 3 October 2015}

\section{Summary}

We have read with interest the updated Review on Corticosteroids for acute bacterial meningitis. We would specifically like to comment on the subject of 'any hearing loss in adults'.

The figure for Analysis 3.2 contains some typographical errors. The figures quoted for the Scarborough (2007) paper for any hearing loss in adults (21/180 on corticosteroids and 37/177 on placebo) are in fact from the paper by Nguyen (2007). The figures quoted for the Thomas (1999) paper (30/96 on corticosteroids and 36/99 on placebo) are in fact the figures from the paper by Scarborough (2007). These errors are not present in other figures for the quoted papers. The Thomas (1999) paper is misplaced in Analysis 3.2.

Analysis 5.10 regroups four studies on any hearing loss in adults according to country income, be it high or low-income. The Scarborough (2007) paper is from Malawi and correctly categorised as from a low income country. The Bhaumik (1998) paper is categorised as from a high income country, but is in fact from India. The earlier text and all other analyses all place the Bhaumik paper in a low income country category. The Nguyen (2007) paper is categorised as from a high income country, but is in fact from Viet Nam. The World Bank defines Viet Nam as a low middle income country. In fact the World Bank now defines India as a low middle income country. The only study clearly from high income countries is that by de Gans (2002) from Europe. 
The study which appears to demonstrate the greatest benefit from steroids on any hearing loss in adults is that by Nguyen (2007) in Viet Nam. In that paper the authors comment on the high proportion of cases of meningitis due to Streptococcus suis, and in Asia this is a recognised cause of deafness. However S.suis is not a cause of meningitis in high income countries. This is another reason why placing the Nguyen study in the high income category is inappropriate. The distinction between adults and children varies by study and the Nguyen paper included individuals over 14 years of age. There is clear evidence for benefit from steroids in reducing deafness from Haemophilus influenzae meningitis in children (Analysis 4.3), but in high income countries the incidence of H.influenzae infection has declined considerably with immunisation (Okike et al, 2014).

Reference

Okike 10 et al. Trends in bacterial, mycobacterial, and fungal meningitis in England and Wales 2004-11: an observational study. Lancet Infectious Diseases 2014;14:301-7.

Yours sincerely,

Rebacca Wong, Medical Student, Medical Student

Cameron Goodwin, Medical Student

Dr P Venkatesan, Consultant in Infectious Diseases

Affiliation: Nottingham University Hospitals NHS Trust, City Campus, Nottingham. NG5 1PB. United Kingdom.

I agree with the conflict of interest statement below:

I certify that I have no affiliations with or involvement in any organization or entity with a financial interest in the subject matter of my feedback.

\section{Reply}

Analysis 3.2 on any hearing loss have been updated to display the correct names with the figures.

Analysis 5.10 has been updated with Bhaumik 1998 in the low-income countries, which did not change the results. We analysed studies in two subsets divided into low-income and high-income countries. Low-income countries had a United Nations Human Development Index of less than 0.7 and high-income countries had an index of 0.7 or higher (UNHDI 2009). We used the UNHDI score that was given to the country at the time the study was performed.

We agree there are differences in epidemiology between studies, therefore we also performed a subgroup analysis for the major pathogens (Analysis 4.1; Analysis 4.2; Analysis 4.3). For all other analyses we pooled all available data irrespective of epidemiology to find an overall effect. We agree that changes in epidemiology over time have occurred, which however, does not influence the results of the meta-analysis. In the applicability of the results it is good to realize the RCTs were performed in different time periods and multiple countries with variable epidemiology.

\section{Contributors}

Matthijs Brouwer

Diederik van de Beek

\section{Corticosteroids for acute bacterial meningitis, 16 October 2015}

\section{Summary}

In their review titled, "Corticosteroids for acute bacterial meningitis", Brouwer et al. conclude that corticosteroids should be given to patients with acute bacterial meningitis in high-income countries, citing a significant reduction in hearing loss and neurological sequelae with corticosteroids. 1 In addition, Brouwer et al. state that corticosteroids provide no mortality benefit in treatment of acute bacterial meningitis. We feel that the results of this systematic review and meta-analysis require further context.

Our assessment of trials included in the review that reported mortality and were deemed to be free of bias reveals an issue that we would like to highlight. Pooling the data for effect of corticosteroids on mortality resulted in a non-statistically significant difference (RR 0.90, 95\% $\mathrm{Cl} 0.80,1.01)$. A surprising inclusion in the meta-analysis was the trial by Scarborough et al., since the population in the trial were primarily patients who were HIV positive (89.7\%) with a mean CD4 count of 102/mm3 (IQR 51 to 169).2 The inclusion of this trial adds significant clinical heterogeneity, since HIV positive patients would be expected to respond in a manner different from their immunocompetent counterparts. A sensitivity analysis that excludes the Scarborough et al. trial from the pooled data results in a statistically significant difference in mortality (RR $0.83,95 \% \mathrm{Cl} 0.72,0.97$ ). While one may argue that the upper bound of the confidence interval is close to the line of no difference, it is important to present the data this way as it is more reflective of the results of a pooling of less heterogeneous data and suggests that there may be benefit in an immunocompetent population.

Four trials included in this review and meta-analysis were deemed to be free of bias (Scarborough 2007, Molyneux 2002, de Gans 2002, Nguyen 2007).2-5 Our assessment is that bias is present in all of these studies that would affect interpretation of the final results. In all four trials, selective outcome reporting is present. Specifically, none of the trials reported all adverse events (AE). In addition, serious adverse events (SAE) data was not included in any of the trials. In two trials, AE were reported only if they were deemed by the investigator to be 
due to the study drug: the Scarborough et al. trial reported that, "[n]ineteen patients had adverse events that were more likely to be due to antibiotics than corticosteroids", while the Molyneux et al. trial reported, "[w]e recorded no deleterious side-effects attributable to use of dexamethasone.".2,3 Another issue with AE reporting in all four trials is the absence of details on how AE were recorded, specifically whether all $A E$ were recorded or if only the first $A E$ reported was recorded. The selective reporting present in these trials impacts the interpretation of the results of the meta-analysis, since a lack of AE data prevents clinicians from determining the net clinical benefit of adjunctive corticosteroids in acute bacterial meningitis.

We respectfully suggest the authors of this review revisit the inclusion of the Scarborough et al. trial in the pooling of mortality data and provide context for interpretation of subsequent results. In addition, a revision of the risk of bias table should be considered to provide readers with appropriate context with which to interpret the results, namely that AE were likely underreported in trials.

References:

1. Brouwer MC, Mclntyre P, Prasad K, van de Beek D. Corticosteroids for acute bacterial meningitis. Cochrane Database Syst Rev. 2015;9:CD004405. doi:10.1002/14651858.CD004405.pub5.

2. Scarborough M, Gordon SB, Whitty CJM, et al. Corticosteroids for bacterial meningitis in adults in sub-Saharan Africa. N Engl J Med. 2007;357(24):2441-2450. doi:10.1056/NEJMoa065711.

3. Molyneux EM, Walsh AL, Forsyth $\mathrm{H}$, et al. Dexamethasone treatment in childhood bacterial meningitis in Malawi: a randomised controlled trial. The Lancet. 2002;360(9328):211-218. doi:10.1016/S0140-6736(02)09458-8.

4. de Gans J, van de Beek D, European Dexamethasone in Adulthood Bacterial Meningitis Study Investigators. Dexamethasone in adults with bacterial meningitis. N Engl J Med. 2002;347(20):1549-1556. doi:10.1056/NEJMoa021334.

5. Nguyen THM, Tran THC, Thwaites G, et al. Dexamethasone in Vietnamese adolescents and adults with bacterial meningitis. N Engl J Med. 2007;357(24):2431-2440. doi:10.1056/NEJMoa070852.

Timothy S. Leung, BScPharm ACPR PharmD Candidate

Aaron M. Tejani, BScPharm PharmD

I agree with the conflict of interest statement below:

I certify that I have no affiliations with or involvement in any organization or entity with a financial interest in the subject matter of my feedback.

\section{Reply}

Based on the chosen inclusion criteria we did not exclude studies from countries with high HIV positivity rates. To identify differences between areas of inclusion, which include HIV positivity but also e.g. malnourishment and access to health care, we performed the subgroup analysis by income status.

We agree there is lack of detail in the adverse events reporting in the included studies and thereby selective reporting. However, we feel this does not merit a full update of the review.

\section{Contributors}

Matthijs Brouwer

Diederik van de Beek

\section{Corticosteroids for acute bacterial meningitis, 11 September 2017}

\section{Summary}

May I comment on the statistical significance of the mortality benefit of corticosteroids when used for patients with Streptococcus pneumoniae (pneumococcal) meningitis as shown in Analysis 4.1.

As a simple rule we consider $P$ values $<0.05$ as indicating statistical significance. On this measure Analysis 4.1 clearly shows that there is statistical significance in the effect of corticosteroids in reducing mortality in pneumococcal meningitis. On this basis numerous guidelines around the world advocate the use of corticosteroids for meningitis in adults, particularly with St. pneumoniae. We need to appreciate more about what underpins this calculation and I would make four points.

1) The study by Girgis et al (1999) is regarded as having a high risk of selection bias. Exclusion of this single study results in loss of statistical significance.

2) The study de Gans et al (2002) on the other hand was an excellent individual study. The overall $P$ value being $<0.05$ is dependent on this study as its exclusion results in loss of statistical significance. This study included patients with suspected meningitis and any of three features: cloudy CSF, CSF leucocyte counts $>1,000 / \mathrm{ml}$ and Gram stain positive CSF.

3) A further analysis of patients in the latter study by de Beek et al (2004) reviewed deaths within 14 days and found no difference between corticosteroid and placebo groups in those who suffered a neurological death (including brain herniation, cerebrovascular complications 
and withdrawal of care because of poor neurological process). However there was a difference, with benefit in the corticosteroid group, in those who had a 'systemic cause' of death (due to septic shock, respiratory failure, multiple-organ dysfunction and cardiac ischaemia).

4) From data in Analysis 4.1 I calculate the relative risk of mortality between the corticosteroid group (168 deaths / 561) vs placebo (203 deaths / 571) as $0.8423(95 \% \mathrm{Cl} 0.7121-0.9964)$ with $\mathrm{P}=0.0453$.

Having only one less death in the placebo group $(202 / 571)$ changes the relative risk to $0.8465(95 \% \mathrm{Cl} 0.7154-1.0016)$ with $\mathrm{P}=0.0522$, or only one more death in the corticosteroid group (169/561) changes the relative risk to $0.8474(95 \% \mathrm{Cl} 0.7166-1.0019)$ with $\mathrm{P}=0.0527$.

Thus is there sufficient power to reach a clinically significant conclusion and do corticosteroids benefit the brain or protect against systemic complications?

We need to be aware that corticosteroids used to be used after head injuries to reduce intra-cerebral inflammation on the basis of a number of small studies, until the large MRC CRASH study actually showed that corticosteroids increased mortality (Edwards et al, 2005).

\section{References}

de Beek D, de Gans J. Dexamethasone and pneumococcal meningitis. Ann Int Med 2004;141:327.

Edwards P, Arango M, Balica L et al. Final results of MRC CRASH, a randomised placebo-controlled trial of intravenous corticosteroid in adults with head injury-outcomes at 6 months. Lancet 2005;365:1957-9.

Dr Pradhib Venkatesan

Consultant in Infectious Diseases

\section{Reply}

Indeed, exclusion of the studies by Girgis would lead to a non-significant p-value for mortality in pneumococcal meningitis. It is also correct that one less death would change the $p$-value towards non-significance. We would like to stress that we have included all results as they were from the studies at hand, of which the selection was based on the criteria described in the methods. In our opinion the margin by which the significance is established does not influence the conclusion of the meta-analysis.

Furthermore, in our opinion the sole focus on mortality in pneumococcal meningitis to decide to advise to for or against dexamethasone in bacterial meningitis patients is not justified. The other analyses on hearing loss, severe hearing loss and neurological sequelae also show a consistent beneficial effect of corticosteroids without harm identified in any of the RCTs.

Additional evidence of the beneficial effect of corticosteroids on mortality is presented in the section "implementation studies" which have shown a reduction in mortality in different countries following introduction of adjunctive dexamethasone as routine therapy. The identified reduction in mortality was similar as described in the European Dexamethasone trial (absolute risk reduction of $10 \%$ for mortality). The comparison to the MRC Crash study does not hold.

\section{Contributors}

Matthijs Brouwer

Diederik van der Beek

\section{Corticosteroids for acute bacterial meningitis, 9 July 2018}

\section{Summary}

In this review abstract, authors report that "corticosteroids were associated with a non-significant reduction in mortality". This may be misleading, and the use of term "non-significant" does not follow Handbook recommendations.

In addition, the summary of findings table grades evidence as moderate and high quality. The methods section does not explain the application of the GRADE process. The discussion section "quality of evidence" does not clearly discuss the rationale for downgrading the quality of the body of evidence. This section also appears to confuse quality with the risk of bias assessments. We would suggest that the authors reassess using the most up-to-date GRADE methods and consider whether the certainty of evidence should be downgraded for risk of bias, inconsistency, and indirectness.

Within their conclusion the authors state: "We recommend a four day regimen of dexamethasone (0.6mg/kg daily) given before or with the first dose of antibiotics". Authors should not make recommendations. Also, this recommendation goes beyond the evidence for two reasons: the subgroup analyses (Analysis 6.1; Analysis 6.2; Analysis 6.3; Analysis 6.4) indicate little or no difference in relation to timing for primary outcomes of mortality and severe hearing loss; there are lower point estimates for the primary outcomes of any hearing loss or short-term neurologic sequelae in the subgroup receiving steroids after first dose of antibiotics.

We note that Prof Diederik van de Beek (senior author of this review) is also senior author of one of the included trials, which contributes a weight of $10 \%$ to the meta-analysis (De Gans 2002). This should be declared as a conflict of interest, and assurance given that the data extraction and quality assessment of this study was independent. 
We would suggest that this review is updated to ensure transparency.

Dr Paul Hine, Clinical Research Assistant

Prof Paul Garner, Co-ordinating Editor, Cochrane Infectious Diseases Group

\section{Reply}

We did not identify the Cochrane Handbook recommendation referred to by Dr. Hine and Prof. Garner after checking the sections 11.7 .1 (general methods for Cochrane reviews $>11$ Presenting results $>$ presenting results in the text $>$ results of meta-analyses) and 11.5 (summary of findings table).

The GRADE assessment was conducted in 2014. This may not have been with the most up-to-date version that is currently available. Although we agree this may change the certainty of evidence, we do not think it justifies revision of the meta-analysis, especially since no new RCTs have been published.

We agree that the recommendation of the regimen goes beyond the results of the meta-analysis as Cochrane meta-analyses are not intended to provide recommendations. As the recommendation complies with the international guidelines on treatment for bacterial meningitis by the IDSA, ESCMID and NICE, we feel revising the meta-analysis for this purpose is not warranted.

We agree this should have been mentioned as a conflict of interest and we have now changed the statement. However, all data extracted from the de Gans 2002 study that were included in the meta-analysis can be verified in the original publication and quality assessment was based on objective criteria. Matthijs C Brouwer independently extracted data and assessed quality.

Although valid points are raised in the comments, the lack of new RCTs and thereby similar conclusions of an updated meta-analysis in our opinion argues against an update.

\section{Contributors}

Matthijs Brouwer

Diederik van der Beek

WHAT'S NEW

\begin{tabular}{lll}
\hline Date & Event & Description \\
\hline 8 November 2018 & Feedback has been incorporated & Authors responded to feedback comments \\
\hline
\end{tabular}

\section{H I S T O R Y}

Protocol first published: Issue 3, 1998

Review first published: Issue 3, 2003

\begin{tabular}{lll}
\hline Date & Event & Description \\
\hline 20 August 2018 & Feedback has been incorporated & Feedback comment added to the review. \\
\hline 11 March 2016 & Feedback has been incorporated & Feedback comments added to the review \\
\hline 3 February 2015 & $\begin{array}{l}\text { New citation required but conclusions } \\
\text { have not changed }\end{array}$ & $\begin{array}{l}\text { Three new implementation trials included in the Discussion. Our } \\
\text { conclusions remain unchanged. }\end{array}$ \\
\hline 3 February 2015 & New search has been performed & $\begin{array}{l}\text { Searches updated. We did not identify any new trials for inclu- } \\
\text { sion. }\end{array}$ \\
\hline 18 January 2013 & New search has been performed & New citation required but conclusions have not changed. \\
\hline 19 June 2008 & New search has been performed & Converted to new review format. \\
\hline
\end{tabular}




\begin{tabular}{lll}
\hline Date & Event & Description \\
\hline 10 November 2004 & Feedback has been incorporated & Comment and reply added to review. \\
\hline 13 April 2002 & New search has been performed & Searches conducted. \\
\hline
\end{tabular}

\section{CONTRIBUTIONS OF AUTHORS}

Matthijs Brouwer (MB) was responsible for co-designing and writing the review, selecting studies, extracting and analysing data. Peter McIntyre (PM) was responsible for co-writing the protocol, co-writing the review and extracting data.

Kameshwar Prasad (KP) was responsible for co-designing and co-writing the review.

Diederik van de Beek (DvdB) was responsible for co-designing and writing the review, selecting studies, extracting and analysing data.

\section{DECLARATIONS OF INTEREST}

Matthijs C Brouwer: none known.

Peter McIntyre: none known.

Kameshwar Prasad: none known.

Diederik van de Beek is a primary author of one of the included trials (de Gans 2002). Matthijs C Brouwer independently extracted data and assessed quality.

\section{SOURCES OF SUPPORT}

\section{Internal sources}

- Academic Medical Center, Netherlands.

AMC Fellowship 2008 (D. van de Beek)

\section{External sources}

- Netherlands Organization for Health Research and Development, Netherlands.

NWO Veni grant 2012 (916.13.078) to M.C. Brouwer; NWO Veni grant 2006 (916.76.023), NWO Vidi grant (016.116.358) to D. van de Beek

- European Research Council, Other.

ERC Starting Grant to D. van de Beek

\section{DIFFERENCES BETWEEN PROTOCOL AND REVIEW}

None.

\section{INDEX TERMS}

\section{Medical Subject Headings (MeSH)}

Acute Disease; Anti-Inflammatory Agents [adverse effects] [therapeutic use]; Developed Countries; Developing Countries; Dexamethasone [therapeutic use]; Glucocorticoids [adverse effects] [*therapeutic use]; Hearing Loss [etiology] [prevention \& control]; Hydrocortisone [therapeutic use]; Meningitis, Bacterial [complications] [ ${ }^{\star}$ drug therapy] [mortality]; Prednisolone [therapeutic use]; Randomized Controlled Trials as Topic

\section{MeSH check words}

Adolescent; Adult; Child; Humans 